$I 19.3 \div 2090$
0620

Geology and Geochemistry of Tertiary

Volcanic Host Rocks, Sleeper Gold-Silver

Deposit, Humboldt County, Nevada

\title{
2090
}

metadc958083 



\section{Geology and Geochemistry of Tertiary Volcanic Host Rocks, Sleeper Gold-Silver Deposit, Humboldt County, Nevada}

By J. Thomas Nash, William C. Utterback, and Wayne S. Trudel

\section{U.S. GEOLOGICAL SURVEY BULLETIN 2090}

Rich bonanza veins and bulk mineable gold and silver deposits formed in a local volcanic field during early stages of basin-and-range extension. Geologic and geochemical relations indicate a major role for normal faulting in ore genesis and preservation

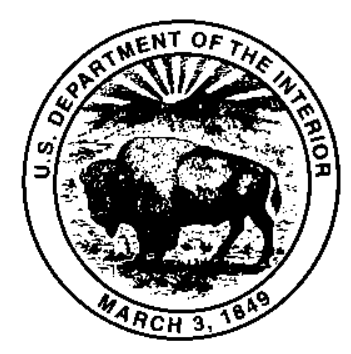

UNITED STATES GOVERNMENT PRINTING OFFICE, WASHINGTON: 1995 


\title{
U.S. DEPARTMENT OF THE INTERIOR BRUCE BABBITT, Secretary
}

\author{
U.S. GEOLOGICAL SURVEY \\ Gordon P. Eaton, Director
}

For sale by U.S. Geological Survey Information Services

Box 25286, Federal Center

Denver, CO 80225

\begin{abstract}
Any use of trade, product, or firm names in this publication is for descriptive purposes only and does not imply endorsement by the U.S. Govemment
\end{abstract}

\section{METRIC CONVERSION FACTORS}

\begin{tabular}{llc}
\hline To convert from & \multicolumn{1}{c}{ To } & Multiply by \\
\hline Inch (in.) & Centimeter (cm) & 2.54 \\
Feet (ft) & Meters (m) & 0.3048 \\
Mile (mi) & Kilometer (km) & 1.609 \\
Ounce, troy (oz) & Gram $(\mathrm{g})$ & 34.4 \\
Ounce, avoirdupois (oz) & Gram $(\mathrm{g})$ & 28.35 \\
Pound, avoirdupois (lb) & Kilogram (kg) & 0.454 \\
\hline
\end{tabular}

Library of Congress Cataloging-in-Publication Data

Nash, J. Thomas (John Thomas), 1941-

Geology and geochemistry of Tertiary volcanic host rocks, Sleeper gold-silver deposit, Humboldt County, Nevada / by J. Thomas Nash, William C. Utterback, and Wayne S.

Trudel.

p. cm.-(U.S. Geological Survey bulletin ; 2090)

Includes bibliographical references.

Supt. of Docs. no.: I 19.3:2090

1. Gold ores-Geology-Nevada-Humboldt County. 2. Silver ores-GeologyNevada-Humboldt County. 3. Geology, Stratigraphic-Tertiary. 4. GeologyNevada - Humboldt County. I. Utterback, W.C. II. Trudel, Wayne S. III. Title. IV. Series.

QE75.B9 no. 2090

[QE390.2.G65]

$557.3 \mathrm{~s}-\mathrm{dc} 20$

[553.4¹'0979354] 


\section{CONTENTS}

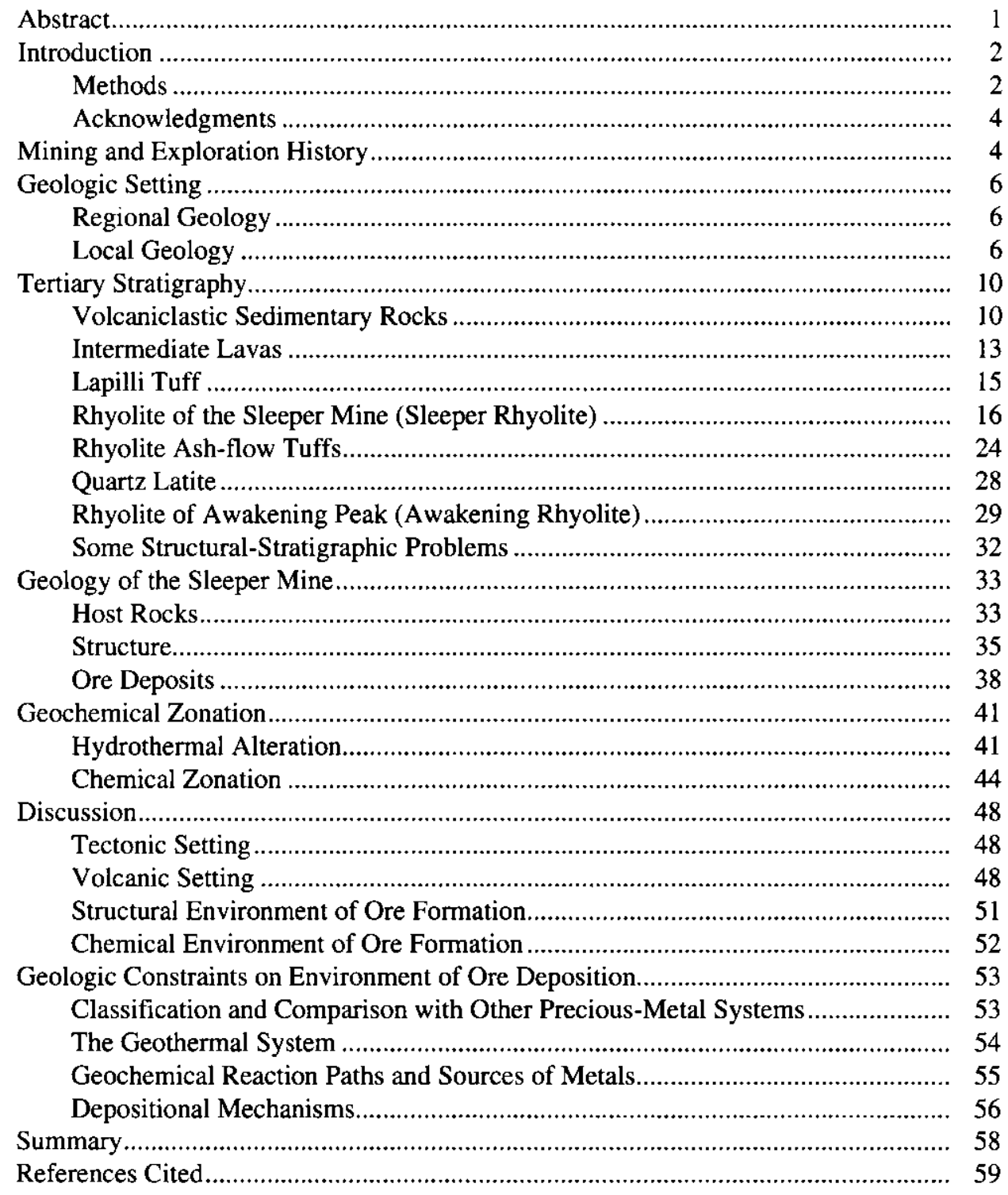

\section{PLATES}

[Plates are in pocket]

1. Map showing geology of Slumbering Hills in vicinity of the Sleeper mine, Humboldt County, Nevada.

2. Map showing geology and hydrothermal alteration in the Sleeper mine, Humboldt County, Nevada. 


\section{FIGURES}

1. Map showing location and geologic setting of the Sleeper mine, Slumbering Hills, Humboldt County, Nev ........... 3

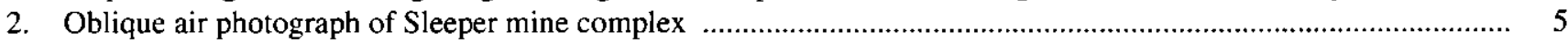

3. Chart showing geochronology of Tertiary events in the Sleeper mine area ....................................................... 6

4. Photograph showing outcrop of typical phyllite and quartzite ......................................................................... 6

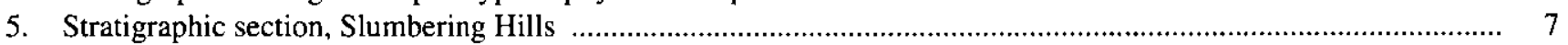

6. Schematic map of Miocene-Holocene faults, western slope of Slumbering Hills ................................................... 9

7. Photograph of conglomerate containing large clasts of quartzite and phyllite .................................................. 10

8. Photomicrographs of volcaniclastic sedimentary rocks .......................................................................... 11

9. Generalized geochemical profiles of Tertiary volcanic rocks at Sleeper mine....................................................... 12

10. Photograph of flow breccia containing clasts of vesicular red and black andesite, west of ZZ-top ........................ 13

11. Photomicrographs of samples of intermediate lavas ..................................................................................... 14

12. Total alkali-silica diagram showing composition and classification of relatively fresh rock samples from Sleeper

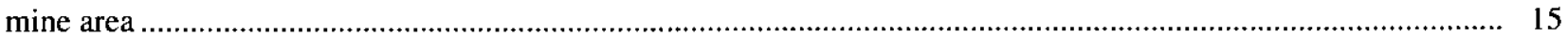

13. Diagram showing normative compositions of Tertiary rock types in Sleeper mine area ................................... 16

14. Photograph showing lapilli tuff with 1- to 2-cm-long clasts of andesite ........................................................ 16

15. Photograph of Sleeper rhyolite exposed on east wall of Wood sub-pit ......................................................... 17

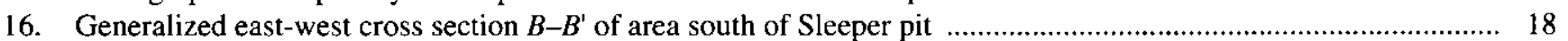

17. North-south geologic cross section $D-D^{\prime}$ through Sleeper deposit .......................................................... 19

18. Generalized map of subcropping and outcropping Tertiary volcanic units near Sleeper mine ................................ 20

19. Photomicrographs of relatively fresh samples of Sleeper rhyolite ..................................................................... 22

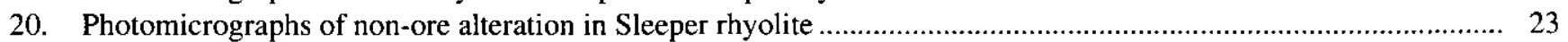

21. Photomicrographs of atypical lithologies in Sleeper rhyolite ..................................................................... 24

22. K-Na-Ca diagram showing chemical changes in Sleeper rhyolite produced by alteration...................................... 26

23. Fe-Mg-alkali diagram showing chemical changes in Sleeper rhyolite produced by alteration .............................. 27

24. Diagram showing abundance of $\mathrm{Zr}-\mathrm{Nb}-\mathrm{Y}$ in fresh and altered Sleeper rhyolite .................................................. 28

25. Photograph of rhyolite ash-flow tuffs exposed on hogback $4 \mathrm{~km}$ northeast of Sleeper mine................................ 28

26. Photomicrograph of sample of welded ash-flow from tuff of Long Ridge........................................................ 29

27. Photograph showing outcrop of typical flow in Awakening rhyolite …........................................................ 30

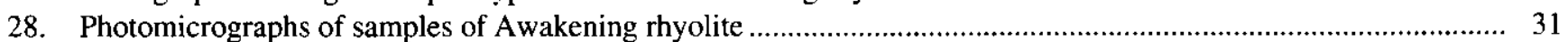

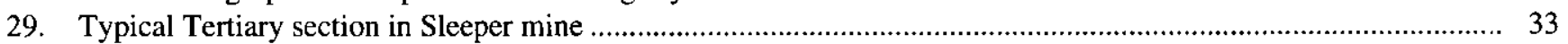

30. Sketch maps showing thicknesses of Tertiary units in Sleeper mine area .......................................................... 34

31. Generalized geologic cross section $C-C^{\prime}$ through northern part of Sleeper deposit ............................................ 36

32. Map of generalized distribution of ore in Sleeper mine ........................................................................... 38

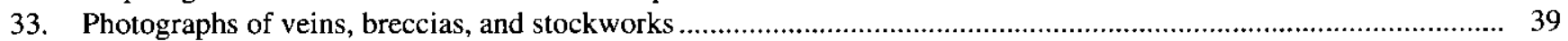

34. Photomicrographs of ore-associated alteration of Sleeper rhyolite ................................................................... 42

35. Geochemical maps of Sleeper thyolite in mine area ................................................................................ 46

36. Geochemical maps comparing reduced and oxidized alteration of Sleeper rhyolite in southern part of mine area .... 49

37. Schematic diagram of Sleeper geothermal system at about 15-16 Ma ............................................................ 56

38. Schematic diagram of Sleeper geothermal system during formation of bonanza veins ........................................... 57

\section{TABLES}

1. Geochronology of Tertiary rocks and alteration, Sleeper mine area.................................................................

2. Chemical composition of various Tertiary volcanic rocks and alteration types ................................................... 25 


\title{
GEOLOGY AND GEOCHEMISTRY OF TERTIARY VOLCANIC HOST ROCKS, SLEEPER GOLD-SILVER DEPOSIT, HUMBOLDT COUNTY, NEVADA
}

\author{
By J. Thomas Nash, William C. Utterback, ${ }^{1}$ and Wayne S. Trudel ${ }^{2}$
}

\begin{abstract}
The world-class deposit of gold and silver at the Sleeper mine formed at about 15-16 Ma in a local volcanic field during the early stages of basin-and-range extension. Bonanza veins of uncommonly high gold grade are the most important ore type, but widespread, bulk-mineable gold-silver-bearing quartz-sulfide stockworks and breccias contain more than 1 million troy ounces of gold. Both types of ore exhibit strong structural control in a brittle, formerly glassy rhyolite body that was either a thick ( $>250$ meters) sequence of flows or a flow-dome complex. Ore-associated alteration is dominated by opaline and microcrystalline silica, with adularia in veins. Andesitic rocks are altered to quartz-sericite-pyrite in ore, or to propylitic assemblages below ore, and distal parts of the rhyolite are devitrified, recrystallized, and argillized. The Sleeper deposit has many of the features of the quartzadularia (sericite) class of epithermal deposits, but differs in its high ratio of gold to silver and lack of ore-associated chlorite and base-metal sulfide minerals.

Basin-and-range extensional tectonics played a major role in creating the geologic framework for ore. The basal Tertiary unit of volcaniclastic sedimentary rocks, about 200 meters thick, formed in an extension-related lacustrine basin. Much of the basin fill was terrigenous clastic material eroded from the Mesozoic basement, but some probably was volcanic debris. Prior to about $17 \mathrm{Ma}$ bimodal volcanism started in the area. Andesitic and basaltic lavas about 150 meters thick are the second Tertiary unit. The mafic lavas are sulfidized and altered over a broad area below ore; this barren alteration may be a pre-ore system or may be related to ore, possibly supplying iron and sulfur to stockwork and breccia ores. Lapilli tuff and tuff cones were deposited locally on the lavas. At about $17 \mathrm{Ma}$ several glassy rhyolite flow-domes

\footnotetext{
'Former Chief Mine Geologist, AMAX Gold Inc., Sleeper Mine, Winnemucca, NV 89445; current address Gold Property Services, 5020 Weikel Dr., Winnemucca, NV 89445.

${ }^{2}$ Senior Mine Geologist, AMAX Gold Inc., Sleeper Mine, Winnemucca, NV 89445.
}

erupted; the largest of these, more than 250 meters thick and preserved over an area of at least 6 by 3 kilometers, is the chief host for ore. Peralkaline rhyolite ash-flow tuffs greater than 80 meters thick were deposited at 16.1 and $15.6 \mathrm{Ma}$, and probably covered the Sleeper rhyolite at the time of ore formation. After a period of substantial erosion, rhyolite lavas were erupted at $13.6 \mathrm{Ma}$ and may have provided protection for ore. Renewed basin-and-range faulting crushed but did not dismember ore zones; ore was down-dropped about 1,000 meters relative to the range crest and protected from erosion.

Zonation of hydrothermal alteration and geochemistry provides a spatial guide to ore, but the features are small, subtle, and not necessarily related to bonanza gold veins, the chief exploration target. The host Sleeper rhyolite is zoned from glassy, to perlitic, argillic, and central silicic alteration zones as the orebody is approached. Mafic lavas show an outer propylitic alteration zone, about $200-400$ meters from ore, and an inner sericitic zone that can carry low-grade goldsilver. Depletion halos of calcium, sodium, barium, and strontium in rhyolite, corresponding to alteration of feldspars and groundmass, are a nonspecific guide to ore. Broad zones of pyrite-marcasite veinlets and disseminations, and anomalous arsenic, molybdenum, and selenium occur hundreds of meters from veins, and accompany bulk-mineable stockwork ores, but are not diagnostic of proximity to veins. Visually identifiable banded opal veinlets, located within 100 meters of major veins, and narrow, erratic zones high in gold and gold:silver but low in base-metal concentrations are most diagnostic of nearby bonanza gold veins.

Reconstruction of district geology indicates that volcanic rocks were only a thin veneer, less than 600 meters thick, at the time of ore formation. The volcanic rocks were limited to a small area, perhaps reflecting a graben, and no major intrusive system larger than 30-meter-thick dikes has been identified. Episodically active normal faults must have penetrated the basement metasedimentary rocks to depths of several kilometers. By analogy to modern geothermal systems, circulation would have penetrated many cubic kilometers of metapelitic rocks. Gold veins at the Jumbo mine, 6 kilometers to the southeast, and in drill intercepts below the 
Sleeper orebody are manifestations of this deep circulation in fractured basement rocks. Reactions in metapelitic rocks would have yielded reducing fluids with high concentrations of potassium, carbon dioxide, methane, and possibly bisulfide ion. Many of the geochemical features of the Sleeper ores, such as low base-metal content and high gold:silver, may have been determined by the metasedimentary source rocks and composition of fluids evolved from them.

Sleeper ores formed at very shallow depth, probably less than 200 meters below the contemporary land surface, and at temperatures of less than $200^{\circ} \mathrm{C}$. Conditions fluctuated repeatedly from local hydrothermal explosion breccias to open-standing large veins filled by delicately banded ore and gangue. Gangue and ore deposition was probably initiated by boiling, fluid mixing, and cooling. Ore-depositing mechanisms or fluid compositions were dramatically different in the two types of ore at Sleeper. Low-grade stockwork and breccia ore may have formed by mixing of a deepsourced water carrying iron, silver, and minor gold with a carbon dioxide-sulfur-rich steam-heated water. In contrast, the bonanza veins that are rich in gold, but very low in iron, sulfur, and base metals, may have formed by a combination of boiling, mixing with a silica-supersaturated fluid from the devitrifying rhyolite, cooling, and upward transport of a sol containing colloidal opal and electrum.

Geochronologic data suggest that ore formation occurred 1-2 million years after emplacement of the rhyolite flows or flow-dome that comprises the Sleeper rhyolite. Alteration, geochemical, and structural features support heat-flow models that indicate that the small volume of rhyolite or related magma chamber could not have provided enough heat for 2 million years in a pluton-driven type of geothermal system. Rather, the geothermal system probably was driven by high regional heat flow and deep meteoric circulation in normal fault and fracture zones. The low basemetal, high gold:silver character of the ores may reflect the dominance of metasedimentary rocks in the geothermal system as sources of metals or of ligands for metal transport. The fabulously high gold grades in bonanza veins do not appear to be directly related to the geologic setting, but to a combination of non-equilibrium processes including boiling, fluid mixing, cooling, and colloidal transport of opal and electrum, and deposition in local, open fractures.

\section{INTRODUCTION}

Miocene volcanic rocks forming a local volcanic center on the west flank of the Slumbering Hills host the world class gold-silver deposit at the Sleeper mine. Recent age determinations on some of the key units (Conrad and others, 1993) indicate that these rocks were emplaced at approximately 17-13 Ma, and that gold-adularia-quartz veins formed at about 15-16 Ma. New mine exposures in the open pit, 25 deep core holes, and more than 2,000 rotary (reverse circulation) drill holes provide abundant information on the nature and distribution of volcanic rocks of the mine area. New descriptions and interpretations presented here provide a geologic and geochemical framework for genetic and exploration models of the Sleeper deposit. Gaps in understanding remain, and geologic studies in the mine and adjacent area continue; thus some parts of this framework may require revision.

Tertiary volcanic rocks of the Slumbering Hills (fig. 1) were mapped and described by Willden (1964) as part of his studies of Humboldt County. The Tertiary rocks were lumped into one unit called rhyolitic and dacitic volcanic rocks for this regional study; Willden used this same broad unit for the McDermitt volcanic field to the north. Willden recognized interbedded water-laid tuff and other sedimentary rocks in this unit, described as Miocene or early Pliocene in age on the basis of fossils in the sedimentary rocks. Since Willden's early work, the Tertiary geology of the McDermitt volcanic field has been more thoroughly studied (Rytuba and McKee, 1984) and provides an important part of the regional framework for the Slumbering Hills. Rytuba (1989) observed some of the peralkaline ash-flow tuffs of the McDermitt volcanic field in the Slumbering Hills; these distinctive rocks yielded dates of 16.1 and 15.6 Ma (Rytuba and McKee, 1984). To 1993, no definitive studies have been made of the Tertiary volcanic rocks in the Slumbering Hills.

Exploration and mining at the Sleeper open pit encountered highly altered volcanic rocks that could not be correlated with those exposed in the Slumbering Hills a few kilometers to the east. Based chiefly on exploration drilling, the altered volcanic rocks were described as latite and quartz latite lava flows, autoclastic breccias, pyroclastic beds, and sills in a section $100 \mathrm{~m}$ thick (Wood, 1988). Differences in degree and type of alteration, and differences in rock appearance in cuttings, core, and pit exposures created confusion regarding rock nomenclature and correlation. Starting in 1988, studies by the USGS and AMAX Gold Inc. of the geology, geochemistry, and mineralogy of ore zones and host rocks were undertaken to better understand the origin of the ore deposit. Preliminary results have been published elsewhere (Saunders and others, 1988; Nash and others, 1991; Nash and Bartlett, 1991). This report focuses chiefly on the geology of Tertiary volcanic rocks of the mine area and develops a framework for exploration and genetic models.

\section{METHODS}

Most of the methods used in this study are traditional ones that need no description. Field observations utilized USGS topographic maps at $1: 24,000$ scale or enlarged to $1: 12,000$ for the Slumbering Hills, whereas studies in the pit 


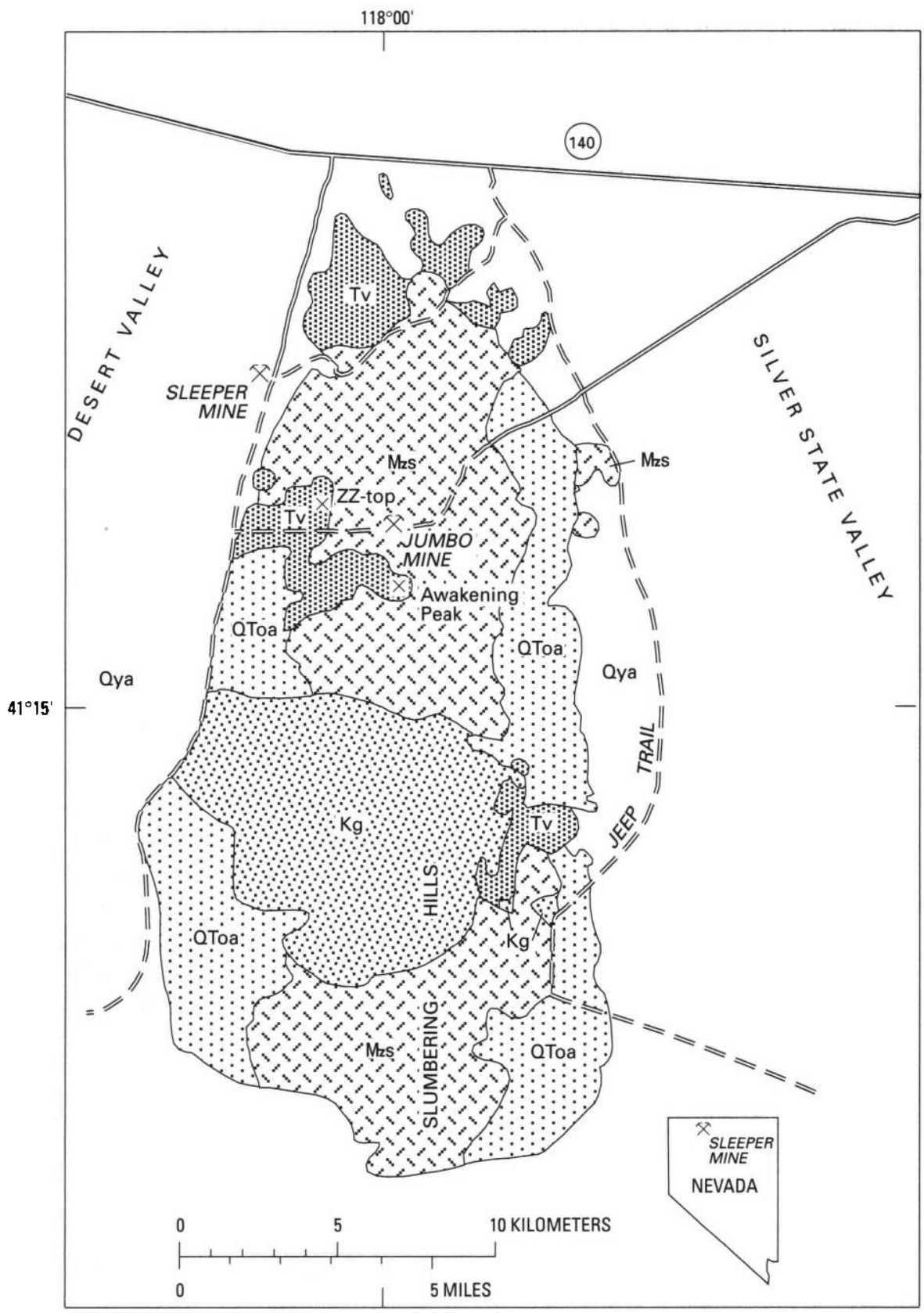

EXPLANATION

Qya Quatemary younger alluvium

Quaternary-Pllocene older alluvium

Tertlary volcanic rocks undifferentiated

Cretaceous granitic rocks

Mesozolc metasedlmentary rocks

Figure 1. Location and geologic setting of the Sleeper mine, Slumbering Hills. Regional geology simplified from Willden (1964).

utilized mine maps at a scale of 1:600 (1 inch=50 feet), and a tape was used to determine locations relative to survey points with an accuracy of about $1 \mathrm{ft}(0.3 \mathrm{~m})$. Thousands of rotary, reverse circulation drill holes were logged by AMAX geologists, some of which were checked by Nash. Twentyfive core holes drilled in 1990-1991 for specific structural and stratigraphic purposes were logged in detail by AMAX geologists, and selected parts were logged and sampled by Nash. Small samples (grab samples) were collected in the pit, or split from core or cuttings for petrographic or geochemical study. Geochemical analyses by the USGS for about 400 samples were reported by Nash and others (1990). Thin sections of cuttings mounted in epoxy were found to reveal many lithologic features not evident under the hand lens or binocular microscope. Another innovative method for this research was routine geochemical analysis of $5 \mathrm{ft}$ $(1.52 \mathrm{~m})$ portions of drill core that were carefully "split" by diamond saw for assays; analyses of more than 3,000 such samples were made by a commercial laboratory using standard induction-coupled plasma spectrometry (ICP) following "total" acid dissolution. Quantitative downhole gammaray spectrometry was performed by a commercial firm on 
many of the research core holes to evaluate that method as a tool for lithologic-stratigraphic mapping.

Geochronologic studies of Tertiary rocks and alteration, undertaken as part of this program, utilized $\mathrm{K} / \mathrm{Ar}$ and ${ }^{39} \mathrm{Ar} /{ }^{40} \mathrm{Ar}$ methods on whole rocks and separated minerals (Conrad and others, 1993). Methods of analysis are described in that report.

Volcanic rock nomenclature is that of Irvine and Baragar (1971), with modifications proposed by the IUGS (Le Bas and others, 1986; Le Maitre, 1989). The names for typical rocks of a stratigraphic unit are deduced from chemical analyses of freshest samples. Rock lithologies are given and permit the user to use descriptive names, such as quartzplagioclase-sanidine porphyry, in place of the chemically defined one (rhyolite).

Note: Measurements herein are metric for units of length, but the unit for assays is troy ounces per short ton $(2,000 \mathrm{lbs})$, abbreviated as oz/ton. Map and drilling units (feet) employed at the Sleeper mine were used in this study but converted to metric for this report. The latest USGS 1:24,000 scale topographic maps of the Slumbering Hills show elevations in meters, whereas mine maps have elevations in feet. Also see table of conversion factors (p. II).

\section{ACKNOWLEDGMENTS}

This report summarizes results of collaborative research made possible by the management of AMAX Gold Inc., and U.S. Geological Survey Development of Assessment Techniques program. Many descriptions presented here are generalized from detailed observations of many of our colleagues; we thank especially Mark Bartlett, Bruce Perry, John Woodman, and Greg Doubek of AMAX Gold Inc., for information and discussions. Jamie Conrad and Ted McKee, USGS, contributed important geochronologic data and interpretations. George Albino and Bill Silberman, USGS, are thanked for their reviews of the manuscript and insightful comments. We also thank USGS chemists for providing chemical analyses of rocks and ores. The skillful editing of Lorna Carter and the graphic artistry of Wayne Hawkins greatly improved the clarity and style of the final product.

\section{MINING AND EXPLORATION HISTORY}

Prior to 1982 recognized ore deposits in the Slumbering Hills (Awakening district) were chiefly gold-quartz veins in Mesozoic metasedimentary rocks. The first recorded production was in 1914, but production was only minor until 1936 when the Jumbo deposit (fig. 1) was brought into production (Calkins, 1938; Willden, 1964). The Jumbo mine, $6 \mathrm{~km}$ southeast of Sleeper, worked narrow stockwork adularia-goldquartz veins by underground and open-pit methods. Early observers (Calkins, 1938) suspected that the adularia-goldquartz veins at Jumbo were related to Tertiary volcanism, in contrast to gold-bearing bull quartz veins that appeared to be related to an older quartz monzonite intrusion. Despite differences in host rocks and structural controls, we suspect that the Jumbo veins and Sleeper deposit may be more similar than previously recognized. The Jumbo veins are now known to be dated at about 17.3 Ma, similar to the date of the Sleeper deposit (Conrad and others, 1993). Deep drilling at Sleeper has intersected adularia-gold veins in metasedimentary rocks below the Sleeper deposit. Adularia-gold-quartz veins in Mesozoic phyllite at the Ten Mile district, $35 \mathrm{~km}$ southeast of Sleeper, formed at 16.3 Ma (Silberman and others, 1973), very similar to Jumbo and Sleeper. Total recorded production for the Awakening district through 1963 was slightly less than $\$ 1,000,000$ (Willden, 1964); production of gold from the Jumbo mine has been modest since then.

The standard topographic map (USGS Jackson Well, 1:24,000, 1982) shows 2 shafts, 3 adits, and 17 prospect pits within $2 \mathrm{~km}$ of the Sleeper mine. These workings, probably from the 1930's, are in or adjacent to altered and veined Tertiary rocks. A shaft now covered by the Sleeper mill served a crosscut heading east into altered volcanic rocks; if the crosscut had been driven westward about $50 \mathrm{~m}$, it would have encountered the Sleeper discovery mineralization.

The Sleeper prospect was located by John Wood of AMAX Exploration, Inc., who noted a scarp stained with iron oxides during an aerial reconnaissance program in early 1982. Follow-up ground mapping and sampling indicated a potential for epithermal precious metals (Wood, 1988). Altered volcanic rocks, which had been prospected previously, were exposed on a pediment. For 2 years the AMAX team tracked geochemical and geologic indications of goldsilver mineralization and utilized $3,536 \mathrm{~m}$ of core and reverse circulation drilling to outline a zone of low-grade (approximately $0.04 \mathrm{oz} / \mathrm{ton}(1.4 \mathrm{~g} / \mathrm{t}$ ) gold) mineralized volcanic rock. Step-out drilling through alluvial cover west of the pediment brought success when drill hole 34 penetrated 102 $\mathrm{m}$ of silicified breccia that averaged $0.82 \mathrm{oz} / \mathrm{ton}(28 \mathrm{~g} / \mathrm{t})$ gold and $1.8 \mathrm{oz} / \mathrm{ton}(62 \mathrm{~g} / \mathrm{t})$ silver, and one very high grade vein containing abundant visible gold. With those indications of high-grade mineralization, drill activity was increased, and in 6 months a "probable" mineable reserve of 1.45 million short tons $(1.32$ million $\mathrm{t})$ averaging $0.32 \mathrm{oz} /$ ton $(11 \mathrm{~g} / \mathrm{t})$ gold and $0.90 \mathrm{oz} / \mathrm{ton}(31 \mathrm{~g} / \mathrm{t})$ silver was defined (Wood and Hamilton, 1991). Stripping of overburden started in June 1985, mining in January 1986, and milling in February 1986.

Mining of the open pit started at about 1,000 tons/day and has increased to the current 65,000 tons/day. Mining first focused on the Sleeper vein in the Sleeper pit; in 1988 the Wood pit was started, and in 1991 a larger, ultimate Sleeper pit $^{3}$ (fig. 2) was initiated to develop deeper parts of veins and

\footnotetext{
${ }^{3} \mathrm{Pit}$ nomenclature is confusing because the original north pit (Sleeper pit) and south pit (Wood) have been included in an enlarged ultimate pit that also is called Sleeper. Mine maps in this report show outlines of the ultimate Sleeper pit and enclosed Wood and Sleeper sub-pits for spatial reference.
} 
more bulk mineable ore for heap leach. The mill, originally designed to process 500 tons/day, has been increased to handle 2,500 tons/day. Vein and adjacent breccia ore with grades in excess of about $0.1 \mathrm{oz} / \mathrm{ton} \mathrm{Au}$ are processed through the mill. Vein ore contains gold coarse enough for gravity recovery, a circuit that accounts for about 20 percent of gold production. Overflow is cyanide leached with high recovery despite some ore with high sulfide content. Neither encapsulation of gold in silica nor presence of sulfides has been a significant problem. Milling is not optimized for silver, but approximately equal amounts of silver and gold are recovered. Broad zones amenable to bulk mining of rock containing about $0.01-0.1 \mathrm{oz} /$ ton Au are treated on four heap leach pads (fig. 2); although not spectacular ores, they contain roughly 1 million troy oz Au (AMAX Gold Inc., 1991; Nash and others, 1991). Approximately 19,000 tons/day are crushed and stacked on heap leach pads (some rock with $0.02-0.006 \mathrm{oz}$ $\mathrm{Au} / \mathrm{ton}$ is stacked without crushing). The upper $100-250 \mathrm{ft}$ (30-75 $\mathrm{m}$ ) of the orebody is oxidized and consumes little cyanide in heap leaching, and deeper sulfidic ores have responded well to routine cyanide leaching. Drilling continues to add new reserves of both high- and low-grade ores, and it is likely that the expanded pit will ultimately produce more than 3 million troy ounces of gold.

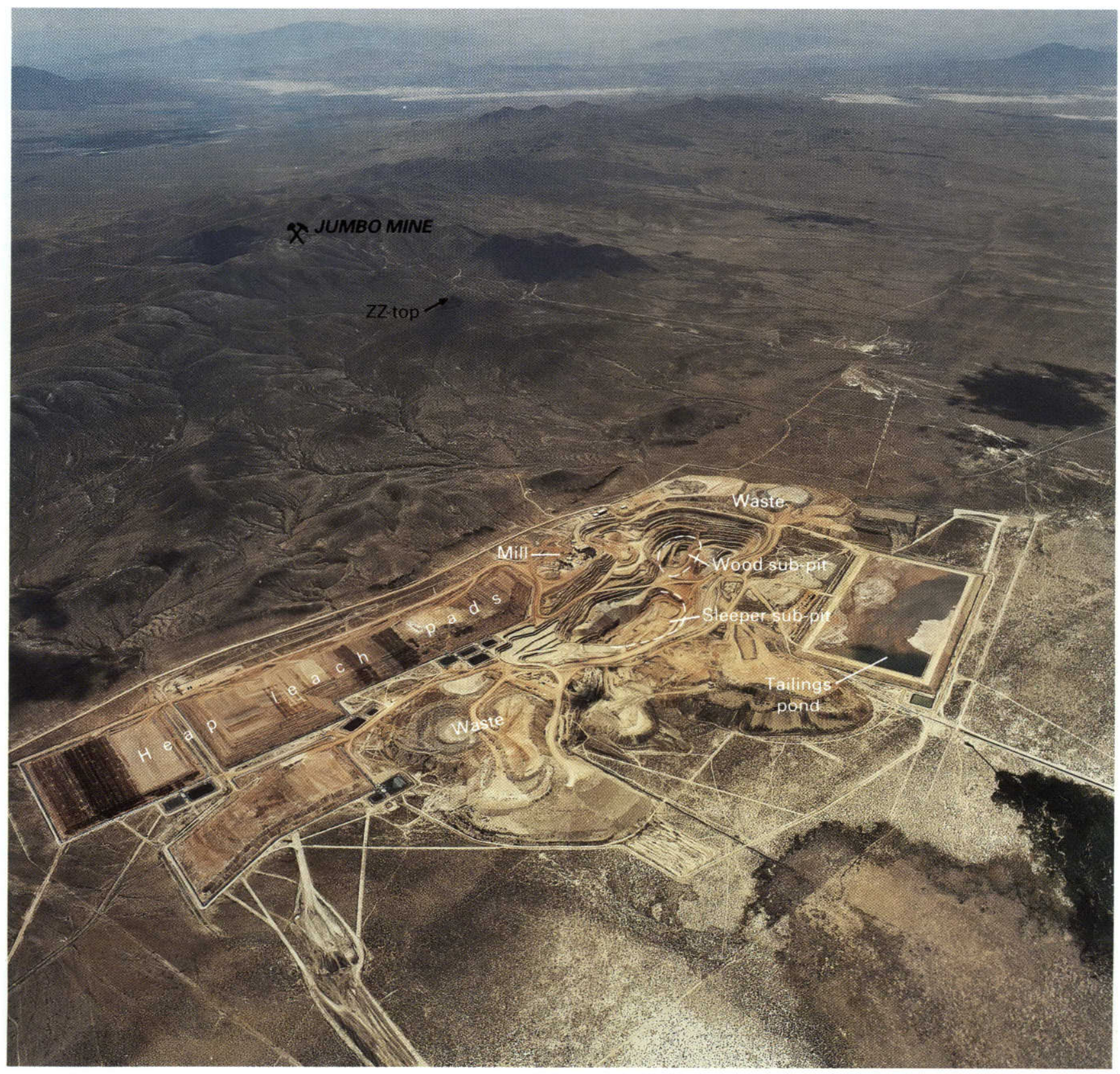

Figure 2. Oblique air photograph of Sleeper mine complex; view to southeast, July 17, 1993. Photograph provided by AMAX Gold Inc. 
Table 1. Geochronology of Tertiary rocks and alteration, Sleeper mine area.

[Simplified from Conrad and others, 1993; leaders (-), not analyzed]

\begin{tabular}{llllc}
\hline Sample No. & \multicolumn{1}{c}{ Unit dated } & Material & K/Ar age (Ma) & $\begin{array}{c}{ }^{40} \mathrm{Ar} /{ }^{39} \mathrm{Ar} \\
\text { age (Ma) }\end{array}$ \\
\hline VP-9 & ash bed & glass & -- \\
Sleeper & supergene alteration & alunite & -.1 & - \\
Ca2030 & Sleeper rhyolite & feldspar & 11.7 & -- \\
Ca2102 & Sleeper rhyolite & feldspar & 11.8 & 16.2 \\
Ca2015 & rhyolite tuff, vitrophyre & feldspar & 13.5 & - \\
Ca2156 & Awakening rhyolite & plagioclase & 13.6 & 12.0 \\
JS-89-14 & Sleeper vein, brecciated & adularia & 13.7 & -- \\
Ca251 & alteration, vein & adularia & 14.1 & - \\
MC8-947 & andesite lava & whole rock & 14.9 & 15.0 \\
JS-89-27 & banded Sleeper vein & adularia & 15.5 & 16.6 \\
JS-89-3b & banded Sleeper vein & adularia & 15.9 & 16.1 \\
JS-89-4b & banded Sleeper vein & adularia & 16.1 & 16.3 \\
G71-435 & Sleeper rhyolite & feldspar & -- & -- \\
AJ-1 & adularia vein, Jumbo mine & adularia & 17.3 & \\
\hline
\end{tabular}

\section{GEOLOGIC SETTING}

\section{REGIONAL GEOLOGY}

The oldest rocks in the area (fig. 1) are Triassic and Jurassic(?) dark, fine-grained slate, phyllite, quartzite, and calcareous phyllite of the Auld Lang Syne Group (Willden, 1964; Burke and Silberling, 1973). These eugeoclinal sedimentary rocks were deformed and metamorphosed to greenschist facies during the Mesozoic. A large granodiorite and monzonite stock was emplaced during the Cretaceous and occupies the central part of the Slumbering Hills (Willden, 1964). Tertiary volcanic rocks unconformably overlie the Mesozoic rocks in the northern part of the range. Many of the volcanic rocks are outflow facies related to the McDermitt volcanic field and its nested calderas about $80 \mathrm{~km}$ to the north (Rytuba and McKee, 1984). Large volumes of peralkaline rhyolite ash-flow tuffs were erupted from the McDermitt calderas from 16 to $15 \mathrm{Ma}$. A local volcanic complex, about $17 \mathrm{Ma}$, was important in localizing the Sleeper deposit (table 1 ; figs. 3,4$)$. The local volcanic rocks included intermediate lavas, a probable tuff cone of lapilli tuff, and a rhyolite lava flow or flow-dome(?). Typical basin-and-range extensional tectonism first developed in lacustrine volcaniclastic rocks (pre-17 Ma), and is subsequently evident as a series of normal faults with north, northeast, and northwest strikes. Highangle extensional fractures and faults were crucial for the development and preservation of the Sleeper deposit.

\section{LOCAL GEOLOGY}

The low hills east of the mine (pl. 1) are underlain chiefly by Triassic and Jurassic(?) metasedimentary rocks including slate, phyllite, and quartzite (fig. 4). Much of this basement has subdued topography and is mantled by a meter or more of Quaternary aeolian sand that greatly hampers geologic mapping. Wood (1988) described a general

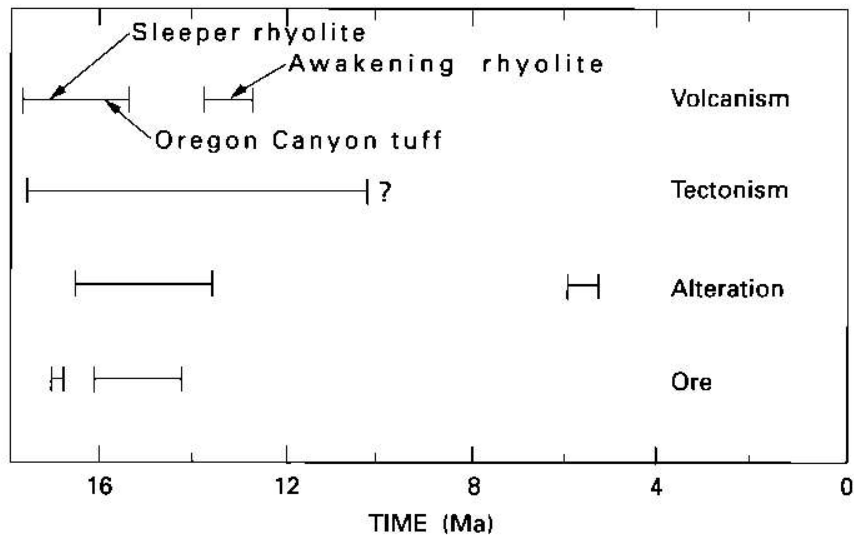

Figure 3. Geochronology of Tertiary events in the Sleeper mine area (Conrad and others, 1993).

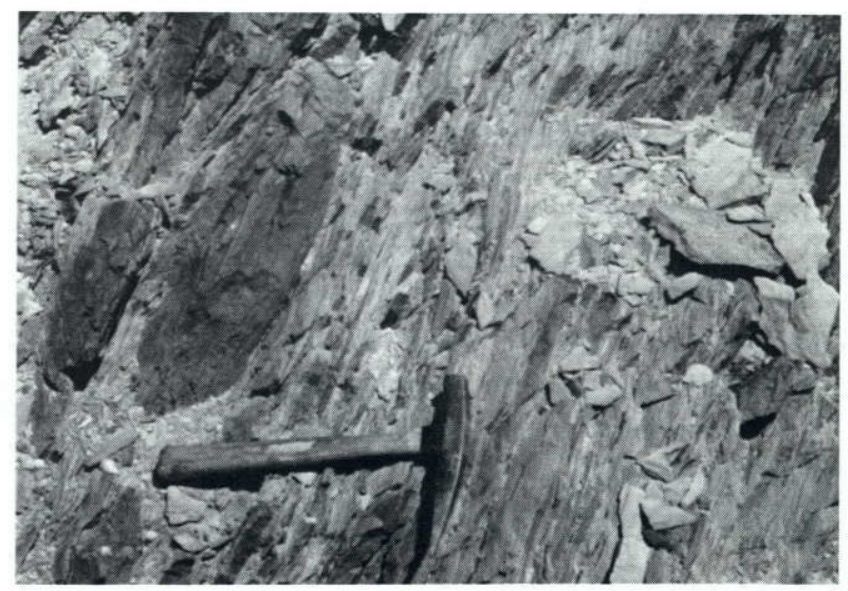

Figure 4. Outcrop of typical phyllite and quartzite with steeply dipping foliation that is parallel to bedding.

stratigraphy for the Mesozoic rocks, lower calcareous units that grade upward into noncalcareous shale and siltstone, and pre-Tertiary thrust faults; we have not studied the 


\begin{tabular}{|c|c|c|}
\hline$\because \because \because 3$ & Qya & Alluvium-Gravel and sand, aeolian, fluvial, and lacustrine deposits $1-3 \mathrm{~m}$ thick \\
\hline & QToa & Older alluvium-Conglomerate, sand, and colluvial deposits with a $2 \mathrm{Ma}$ ash bed; to $>70 \mathrm{~m}$ thick \\
\hline & & Basalt dikes-Aphyric to sparsely porphyritic basalt with fine plagioclase phenocrysts; dark brown; 1-12 $\mathrm{m}$ thick \\
\hline & Tar & $\begin{array}{l}\text { Awakening rhyolite-Dark-colored quartz-plagioclase-sanidine porphyry flows, generally glassy and little altered; pyroxene, } \\
\text { amphibole, and biotite in groundmass. Top is eroded; preserved thickness up to } 180 \mathrm{~m}\end{array}$ \\
\hline & Trt & $\begin{array}{l}\text { Rhyolite tuff-Peralkaline welded tuff, white ash-fall tuff, and two basal vitrophyres. Top is eroded; preserved } \\
\text { thickness reaches about } 80 \mathrm{~m}\end{array}$ \\
\hline & Tsr & $\begin{array}{l}\text { Sleeper rhyolite-Generally massive flows of quartz-plagioclase-sanidine rhyolite; pervasively altered but some glassy } \\
\text { groundmass survives; top eroded; preserved thickness to }>250 \mathrm{~m} \text {. Basal layers characterized by biotite, } \\
\text { flow-breccia, and possible crystal tuff. Associated dikes and sills have same composition as typical flows }\end{array}$ \\
\hline & Tqi & Quartz latite-Altered quartz-feldspar porphyry dorne and dikes. Possibly related to rhyolite of Sleeper mine \\
\hline & TIt & $\begin{array}{l}\text { Lapilli tuff- Lapilli tuff with coarse clasts of many volcanic rock types, grading upward into fine-grained tuff; } \\
0-40 \mathrm{~m} \text { thick. Top variably eroded }\end{array}$ \\
\hline & Til & $\begin{array}{l}\text { Intermediate lavas-Dacitic to basaltic flows and flow breccias, interbedded in lower part with volcaniclastic } \\
\text { sedimentary rocks; about } 150 \mathrm{~m} \text { thick. Plagioclase porphyry (dacite) and pyroxene basalt flows near top of unit }\end{array}$ \\
\hline & Tvs & $\begin{array}{l}\text { Volcaniclastic sedimentary rocks-Basal conglomerate and wacke grading upward into massive to weakly bedded } \\
\text { tuff or siltstone; } 0 \text { to } 160 \mathrm{~m} \text { thick }\end{array}$ \\
\hline xisisisisisy & Mas & $\begin{array}{l}\text { Mesozoic metasedimentary rocks- Phyllite, slate, quartzite, calcareous phyllite, and marble; folded and } \\
\text { possibly thrust faulted. Thickness not known; angular unconformity at top }\end{array}$ \\
\hline
\end{tabular}

Figure 5. Stratigraphic section for the Slumbering Hills.

pre-Tertiary geology sufficiently to offer new information. Two dikes of altered Cretaceous monzonite were observed in the foothills, as well as numerous veins of milky bull quartz in metasedimentary rocks. Most of the bull quartz veins have been prospected, but none in the study area was productive.

Tertiary volcanic rocks unconformably overlie and intrude the metasedimentary basement. A preliminary Tertiary section reported by Nash and others (1991) has been revised on the basis of new geologic and geochronologic studies. Current information suggests the following Tertiary sequence (fig. 5): (1) Volcaniclastic sedimentary rocks up to about $200 \mathrm{~m}$ thick. The age has not been determined, but probably is Miocene. Lithologies are highly variable, including conglomerate, wacke, siltstone and probable tuff, and some interbedded intermediate-composition flows that dominate the overlying unit. (2) Intermediate-composition lava flows and breccias, with minor interbedded volcaniclastic rocks. The total thickness of this unit is about $150 \mathrm{~m}$ in the mine area. The lavas commonly are altered, but original compositions appear to be chiefly andesite with lesser basalt. (3) Lapilli tuff, in part containing felsic pumice fragments; thickness is highly variable, ranging to more than $40 \mathrm{~m}$ (top eroded). The lapilli tuff is recognized only in the mine area, but these soft rocks are poorly represented in drill cuttings and outcrop. (4) The rhyolite of Sleeper mine, having coarse plagioclase, sanidine, quartz, and sparse to no mafic phenocrysts. Age determinations (Conrad and others, 1993; table 1) are inaccurate because of pervasive alteration; the best estimate is $17 \mathrm{Ma}$, but could be somewhat older. The top of the rhyolite is eroded, but preserved thicknesses range to more than 250 m over an area of about 6 by $3 \mathrm{~km}$. This rhyolite, the host for $>90$ percent of ore at Sleeper, is hereinafter 
called Sleeper rhyolite to distinguish it from other rhyolites in the area. Texturally and compositionally similar dikes and sills cut Mesozoic and Tertiary rocks in the foothills and are intersected by drill holes below the pit. This unit is chiefly flows related to several flow-domes. An altered quartz latite intrusive body near the Jumbo mine and dikes of similar lithology may be the same age as the Sleeper rhyolite and related to it. (5) Rhyolite ash-flow tuffs as much as $80 \mathrm{~m}$ thick, correlated with the ash-flow tuff of Oregon Canyon and the tuff of Long Ridge (Rytuba, 1989), dated at 15.6 and 16.1 Ma (Rytuba and McKee, 1984). These distinctive tuffs overlie intermediate flows $3 \mathrm{~km}$ northeast of the mine, but contacts with Sleeper thyolite have not been found. A basal vitrophyre from the ash-flow tuff of Oregon Canyon northeast of the mine yielded an age of 16.2 Ma (table 1). (6) Younger, little-altered thyolite lavas of Awakening Peak, about $150 \mathrm{~m}$ thick, that occur chiefly 3-7 km southeast of the mine and are well exposed on Awakening Peak. The glassy, unaltered flows occur within $100 \mathrm{~m}$ of prospects south of the Jumbo mine, consistent with their being younger than Jumbo ore $(17.3 \mathrm{Ma})$ and supported by one age determination of 13.6 Ma (table 1). This younger rhyolite unit, hereinafter called Awakening rhyolite, is texturally and compositionally very similar to the Sleeper rhyolite, causing confusion in mapping and logging of drill cuttings. (7) Basalt dikes which occur along north-striking faults, cut all other units, and could be of Pliocene age, but no radiometric age determinations have been made.

Alluvial deposits cover the Sleeper gold deposit and also mantle most of the foothills to the east. Several types of alluvium are present but are generalized into two units on the geologic map (pl. 1). Older alluvial deposits (Pliocene to Quaternary) in the hills occur on upland surfaces that are dissected by modern drainages. A scarp at about 1,320-1,340 m elevation, probably a wave-cut surface from Pleistocene Lake Lahontan (Willden, 1964), truncates the older alluvium along the east side of Desert Valley. The older alluvium comprises a variety of unsorted, coarse- to fine-grained detritus including colluvial, alluvial fan, and aeolian deposits. Exposures in arroyos indicate that this older alluvium is commonly 2-5 m thick. Many of the arroyos do not expose bedrock in the lower foothills, thus information on bedrock is lacking across large areas below about $1,600 \mathrm{~m}$ elevation (pl. 1). Technically, the surficial material generally is Holocene aeolian sand. Most of the coarse detritus is metasedimentary rock debris. Mesozoic metasedimentary rocks probably underlie the older alluvium in most of the foothills. Exposures in the Sleeper mine show that the older alluvium there is $20-50 \mathrm{~m}$ thick, consisting of basal gravel and sand beds and channel-fill, overlain by well-bedded lacustrine silt and clay. Two beds of air-fall ash are present in the lacustrine sequence; the ash yielded a K/Ar age of $2.1 \mathrm{Ma}$ (Conrad and others, 1993), indicating that the older alluvium is, in part, Pliocene in age. Gravel beds $0-10 \mathrm{~m}$ above Sleeper rhyolite in parts of the Sleeper open pit contain enough gold to merit mining; the alluvial gold zones are about $30-240 \mathrm{~m}$ west of bonanza veins that appear to be the source of the gold and siliceous detritus.

Younger alluvium (Quaternary) occurs in the lower valley and drainages that cut upland surfaces. These deposits comprise aeolian sand, alluvial gravel, and fanglomerate. Exposures in the open pit show that the younger alluvium rests on older alluvium that is at least $2.1 \mathrm{Ma}$ in age, as described previously.

A local unit of Tertiary conglomerate is exposed in the north and west wall of the Sleeper pit. Poorly sorted, massive to thick-bedded boulder and cobble conglomerate rests unconformably on Sleeper rhyolite. Maximum thickness is $18 \mathrm{~m}$, adjacent to a normal fault, and thins to about $8-10 \mathrm{~m}$ $400 \mathrm{~m}$ west of the fault. Clasts are predominantly basalt, phyllite, and quartzite at the east, where they range to more than $60 \mathrm{~cm}$ diameter, but are chiefly Sleeper rhyolite and mineralized rhyolite to the west, where there are enough clasts of gold-quartz veins to make ore with about $0.1 \mathrm{oz}$ $\mathrm{Au} / \mathrm{ton}$. Clasts in the gold-bearing conglomerate are generally subangular and from 4 to $20 \mathrm{~cm}$ in diameter. Matrix in the conglomerate, brown clay and sand that is distinct from overlying pale-greenish-gray lacustrine silt and sand, comprises $40-60$ percent of various beds. Thin lenses of conglomerate are in the lower part of the thin-bedded lacustrine sequence (Pliocene older alluvium), probably reworked from the underlying conglomerate.

Tertiary structure is a mosaic of normal faults with predominant north, northwest, and northeast strike (fig. 6). Layered volcanic rocks typically dip $25^{\circ}-40^{\circ}$ E., reflecting tilt during extensional faulting (pl. l, section $A-A^{\prime}$ ). North-striking normal faults on the west margin of the Slumbering Hills are well exposed in the pit, inferred from drilling, and indicated in and along Tertiary units in the foothills. These are basin-and-range faults with post-ore displacements of tens of meters. A generalized cross section across the western slope of the Slumbering Hills (pl. 1) provides a minimum estimate of the amount of normal faulting. The total downdrop of the mine area and orebody is about $900-1,000 \mathrm{~m}$ relative to the crest of the range, using the pre-Tertiary surface as a datum. Normal faults with northwest and northeast strikes are less obvious than those with northerly strike but are indicated by pit exposures and termination of rock units in the foothills, as well as by electromagnetic surveys (Wood, 1988). The displacement on these faults is normal; lateral displacement has been suspected but cannot be documented. Multiple episodes

Figure 6 (facing page). Schematic map of Miocene-Holocene faults in western Slumbering Hills. Faults are approximately located. D, downthrown side. North-striking basin-and-range faults have largest displacements (down on west side), but northwest- and northeast-striking normal faults also are important. Base from U.S. Geological Survey 1:24,000 Jackson Well (1982), Awakening Peak (1982). 
GEOLOGIC SETTING

9

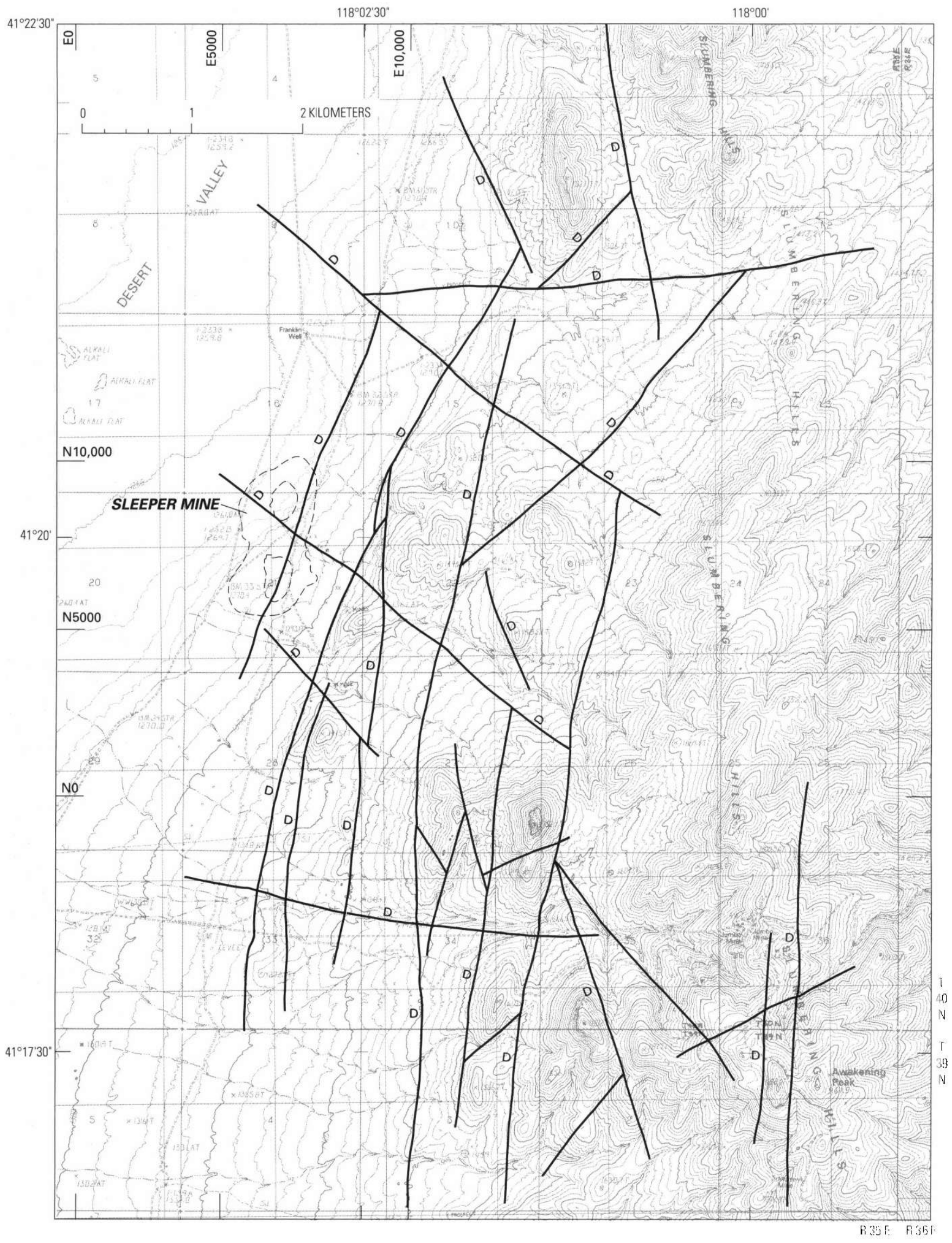


of movement are likely for all of the faults because crosscutting relations differ from place to place. Miocene (about 18-14 Ma) displacements are inferred to have resulted in differential erosion of volcanic rocks prior to eruption of Awakening rhyolite, most notably deep erosion of intermediate lavas southeast of the mine (pl. 1).

The subdued topography of the Slumbering Hills belies complex, episodic extensional tectonism from sometime prior to $17 \mathrm{Ma}$ to the present. Early stages of basin-and-range normal faulting (pre-13 Ma) are reflected in the general distribution of Tertiary rock units. The first evidence of extension is the probable lake that collected the volcaniclastic sedimentary rocks, the basal Tertiary unit in the area. The presence of interbeds of conglomerate and wacke between flows of intermediate lavas suggests episodic faulting and uplift during that interval. Basin-and-range faults near the Sleeper mine are filled by feeder dikes of several ages and compositions, and probably controlled the location of one or more tuff cones and inferred associated craters (maars) in the vicinity of the current western margin of the Slumbering Hills. Normal faults also probably controlled the location of feeder dikes for Sleeper rhyolite at about $17 \mathrm{Ma}$, as well as somewhat later fracture-controlled silicification. The Sleeper vein and other bonanza veins fill steeply dipping N. $10^{\circ} \mathrm{E}$. fault or fracture zones that were open during extension at 14-16 Ma. Uplift and erosion of possibly $1,000 \mathrm{~m}$ of rocks between 17 and $13 \mathrm{Ma}$ are indicated by the unconformable deposition of Awakening rhyolite over the Jumbo orebody near the crest of the Slumbering Hills. Deposition of the 13.6Ma Awakening rhyolite on Sleeper rhyolite $1 \mathrm{~km}$ south of the mine suggests that the orebody may have been exhumed by that time, then temporarily covered and protected by the younger rhyolite. Several normal faults from 1 to $3 \mathrm{~km}$ south and east of the mine are filled by dikes and flow-domes of Awakening rhyolite (pl. 1).

\section{TERTIARY STRATIGRAPHY}

\section{VOLCANICLASTIC SEDIMENTARY ROCKS}

The basal Tertiary unit is a heterogeneous mixture of coarse- to fine-grained sedimentary rocks having massive to laminated bedding (fig. 7). Very little is known about this unit because it is very poorly exposed northeast of the mine and was cut by only five deep core holes. Fifteen deep rotary holes penetrated the unit, but the cuttings give very little information on lithology other than to suggest it is probably weakly lithified and rich in clay. Based on the core holes, the thickness ranges from about 37 to $155 \mathrm{~m}$. The top is a subjective pick of where interbedded andesitic flows become predominant. Amounts of volcaniclastic sedimentary rocks decrease and conglomerate is rare in the overlying intermediate lavas unit. The basal $20 \mathrm{~m}$ is chiefly conglomerate (fig. $8 A$ ) to very coarse sandstone or wacke having prominent angular to subangular clasts of quartzite, phyllite, and limestone up to $2 \mathrm{~cm}$ in diameter. These coarse clastic deposits can be either matrix- or clast-supported. Beds appear to be less than $0.5 \mathrm{~m}$ thick, but can aggregate as much as $3 \mathrm{~m}$. Higher in the section finer grained, massive to laminated sedimentary rocks predominate, chiefly tan to pale-green mudstone and siltstone (fig. $8 B-D$ ). Outcrops of these rocks are rare. Arroyos northeast of the mine expose massive, soft, clay-rich rocks that are as nondistinct as those in drill core. Outcrops of volcaniclastic rocks $5 \mathrm{~km}$ northeast of the mine (pl. 1) are clay-rich, weakly bedded sandstone or wacke that appear to be clastic lenses between intermediate flows. A small dump from a shaft $4 \mathrm{~km}$ northeast of the Sleeper mine contains indurated conglomerate that resembles basal conglomerate cut in drill core.

The age and character of this unit are not well established. Its age is thought to be Miocene, but it could be older. This basal Tertiary unit consistently rests unconformably on Mesozoic metasedimentary rocks, but lithologically similar rocks are interbedded with the intermediate lavas of presumed Miocene age (pre-17 Ma).

Lithology. Relatively few samples of volcaniclastic rocks have been studied geochemically because none are exposed in the pit, and only five core holes are deep enough

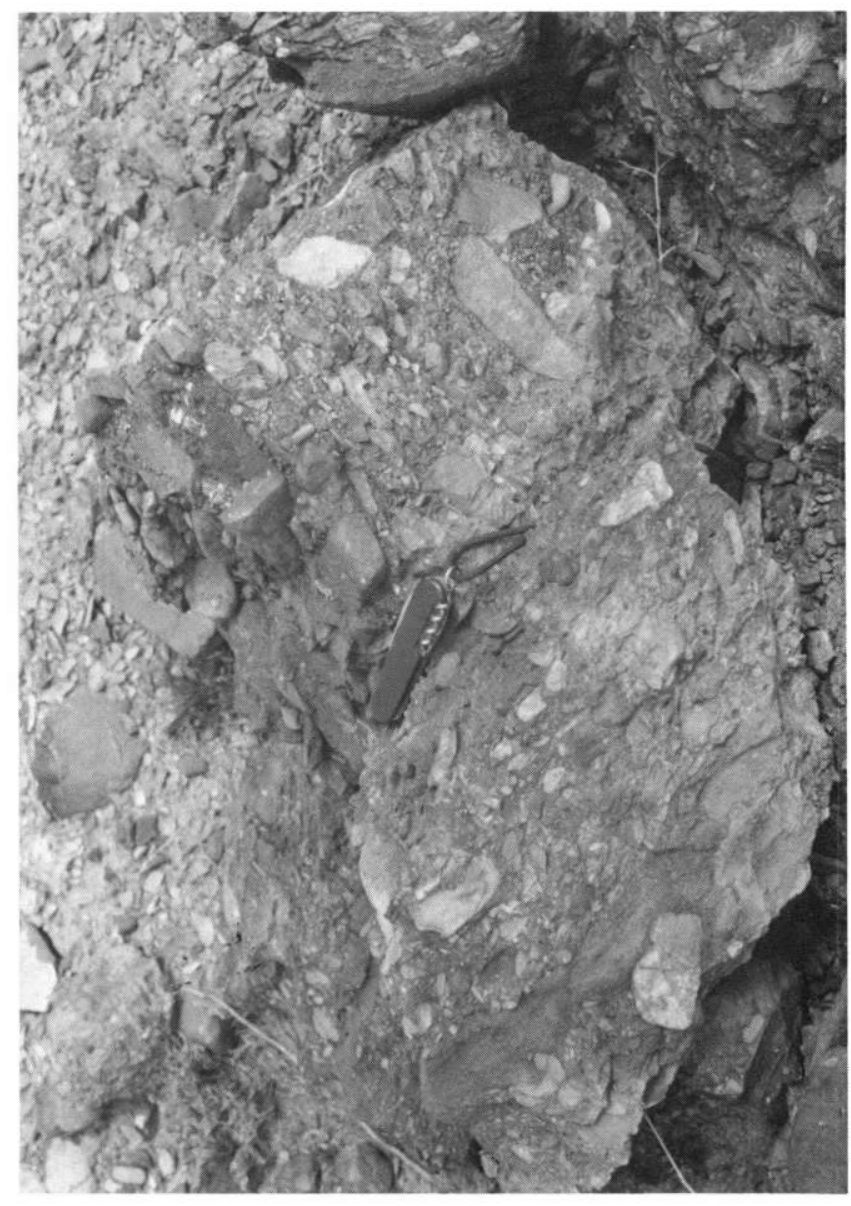

Figure 7. Conglomerate containing clasts of quartzite and phyllite up to $18 \mathrm{~cm}$ long, from dump at shallow shaft $4 \mathrm{~km}$ northeast of Sleeper mine. 

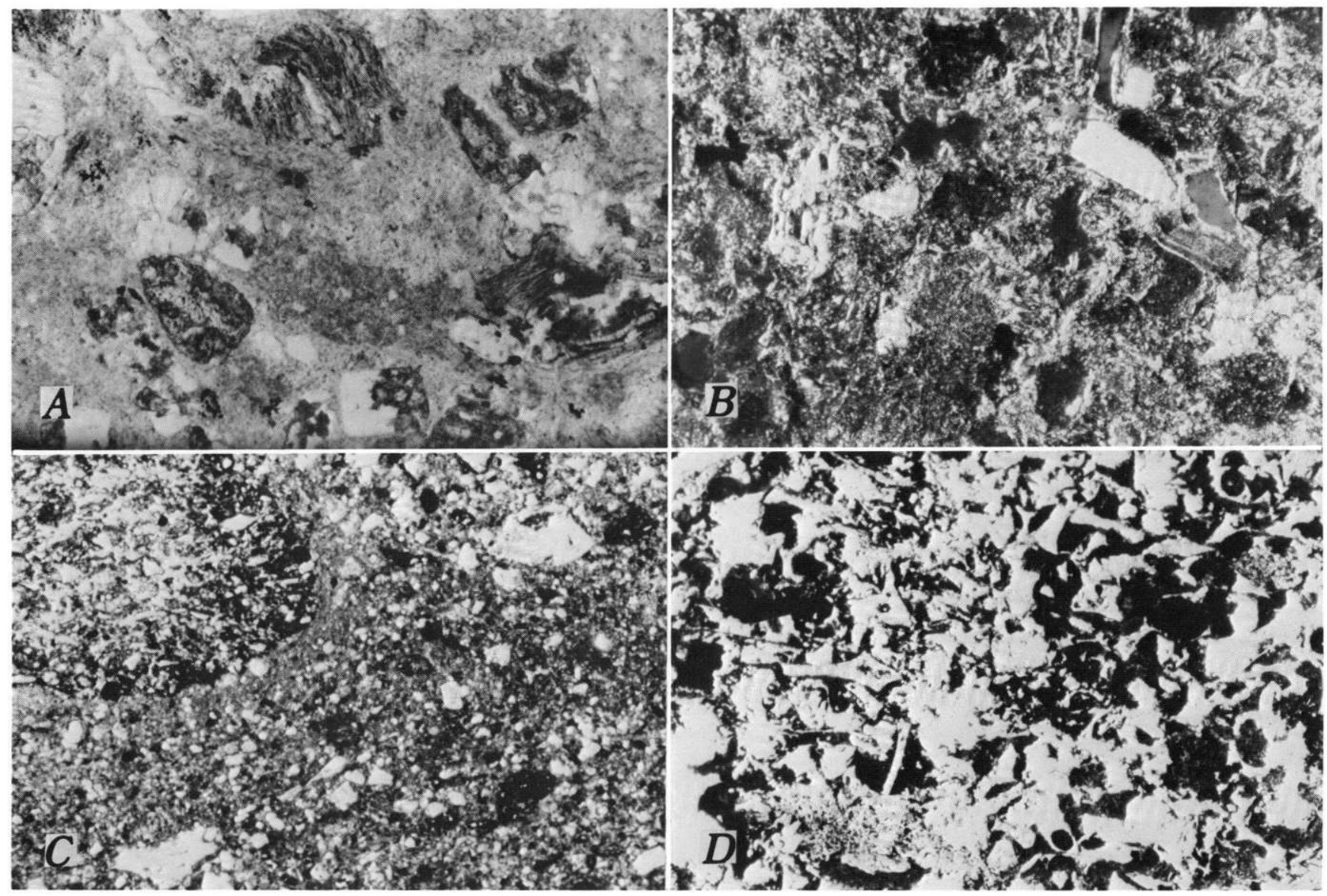

$0.5 \mathrm{~mm}$

Figure 8. Photomicrographs of volcaniclastic sedimentary rocks. A, Conglomerate in basal part, containing clasts of limestone and phyllite in a matrix of clay. Parallel light. $B$, Poorly sorted sandy wacke of uncertain origin. Coarser angular clastic fragments are typically quartz, and detrital phenocrysts or volcanic rock fragments are not seen. Crossed polarizers. $C$, Hematitic siltite with poorly sorted angular quartz grains. Parallel light. $D$, Green mudstone with shard-shaped forms pseudomorphosed by calcite. Pervasive alteration has turned rock to a quartz-calcite-chlorite-pyrite assemblage. Parallel light.

to return samples. Megascopically visible lithic clasts range up to $1 \mathrm{~cm}$ in size in conglomerates, and clasts less than 1 mm diameter of black phyllite or quartzite are sporadically present in amounts of less than 10 percent in the wackes. Petrographic study confirms that the clasts are from Mesozoic basement phyllite, slate, marble, and quartzites. No clasts of volcanic rocks or volcanic phenocrysts have been recognized. The more typical fine-grained sedimentary rocks are as nondistinctive in thin sections as they are megascopically: layering is generally absent, grains coarser than about $20 \mu \mathrm{m}$ (micrometers) are recognizable as coming from a metasedimentary source, but the abundant clay-size material offers few clues as to origin. Only rarely can shapes suggestive of glass shards be discerned (fig. $8 D$ ), and clasts of volcanic rocks have not been recognized.

The volcaniclastic sedimentary rocks are generally soft and rich in clay, except for interbeds of wacke and conglomerate that tend to be cemented by calcite. The abundance of clay, the common pyrite, and massive fabric and pale colors give the impression that the sedimentary rocks were overprinted by a pervasive propylitic hydrothermal alteration that probably obscured primary color lamination and destroyed labile rock clasts. The limited exposure in five drill cores does not provide an opportunity to determine lateral changes that might otherwise permit better determination of primary composition and diagenetic alteration. The postulated alteration is not controlled by any obvious fractures, probably because these rocks are too soft and incompetent to sustain open fractures. The age of the alteration is not readily determined because no structures or contacts suggest age relative to overlying rocks and alteration.

Chemistry. Chemical analyses indicate a wide range in major element composition that is consistent with lithologic variability. Concentrations of $\mathrm{Ti}(0.1-0.3$ wt. percent $), \mathrm{V}$ (30-75 ppm), Sc (5-10 ppm), and $\mathrm{P}(0.04-0.08$ wt. percent) are roughly the same as that of Mesozoic phyllite and slate, 


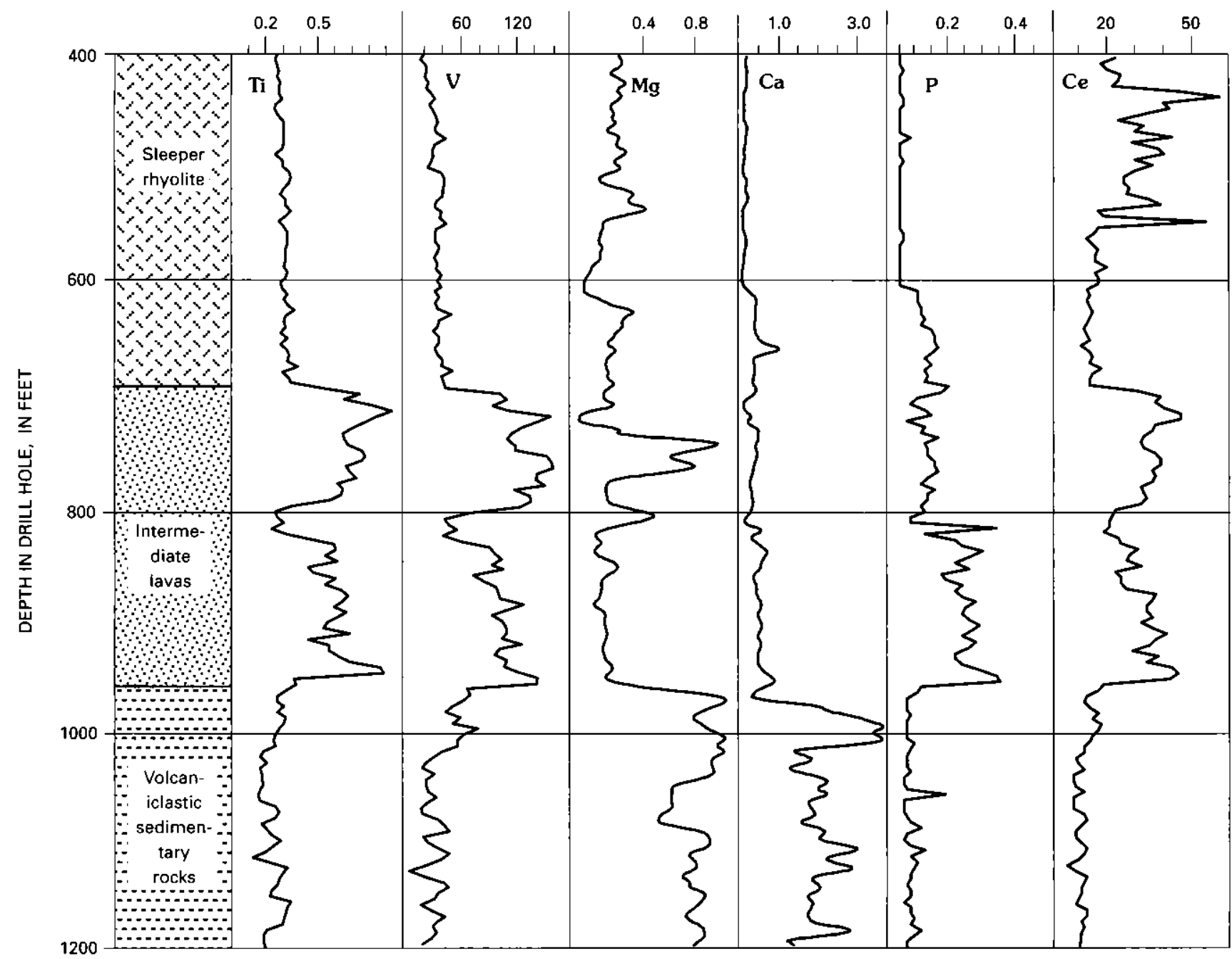

Figure 9. Generalized geochemical profiles of Tertiary volcanic rocks at Sleeper mine. Data plotted are for continuous chip samples (5 ft composite samples), analyzed by ICP. V and Ce in parts per million; others in weight percent.

and less than flows of intermediate lavas (fig. 9). Concentrations of $\mathrm{Ca}, \mathrm{Mg}, \mathrm{K}, \mathrm{La}, \mathrm{Ce}$, and many minor elements are erratic, probably reflecting mobilization or addition during alteration to clay minerals.

Discussion. The origin of these clay-rich rocks is ambiguous. Evidence exists for a substantial input of Mesozoic detritus, including phyllite, quartzite, chert, limestone, and clays derived from them during weathering. There is some direct evidence for tuffaceous input, possibly as air-fall material, but not as much as the initial megascopic features (massive beds of green claystone) suggest. Post-depositionalhydrothermal alteration probably created some of the clay, and it is difficult to determine how much was terrigenous clay or volcanic ash. The lack of a mafic to intermediate geochemical signature, as in overlying flows, may be an indication that much of the clay was derived from the Mesozoic metasedimentary basement.

The volcaniclastic sedimentary rock unit probably was deposited under mixed debris-flow, fluvial and lacustrine conditions accompanying Miocene uplift and extension that marked the onset of basin-and-range tectonism. The coarse, largely unsorted clastic materials quite clearly reflect torrential input from the Mesozoic basement a short distance to the east, although our data from drill core do not permit paleocurrent analysis. Only a small proportion of beds are finely laminated; these bedding forms probably reflect lowenergy subaqueous sedimentation. The seemingly massive beds do not obviously reflect deltaic or lacustrine sedimentation, although this character might possibly be explained by bioturbation. The association of these massive beds with other bedded sedimentary rocks suggests some general variety of subaqueous sedimentation.

Miocene, extension-related, lacustrine volcaniclastic basins have been recognized elsewhere in western Nevada. Near Midas, about $100 \mathrm{~km}$ to the east, thinly laminated tuffaceous lacustrine deposits accumulated at about 15-17 Ma during a hiatus in bimodal volcanism (Wallace, 1991). In west-central Nevada, the Esmeralda Formation filled an 
extension-related lake (Stewart and Diamond, 1988). Sedimentary rocks in the Esmeralda Formation (Robinson and others, 1968) resemble those at Sleeper, but they contain clearly defined airfall tuffs and reworked tuffs, and coal beds occur low in the section. Siliciclastic (nonvolcanic) sedimentary deposits are abundant only along the margins of the Esmeralda basin, a setting that may be analogous to that of the Sleeper area.

Conglomerate in western Pershing County (Johnson, 1977), $85 \mathrm{~km}$ southwest of Sleeper, closely resembles the volcaniclastic sedimentary rock unit. The conglomerate and debris flow in the Kamma Mountains (shown to Nash by G. Albino, 1993) is a thick and widespread unit of poorly constrained (early Miocene?) age. Well exposed because it is silicified, the Kamma area conglomerate is quite clearly an orogenic deposit of unsorted to weakly sorted pre-Tertiary basement phyllite and quartzite. The Kamma unit lacks the thick silt deposits of the Slumbering Hills unit; it may otherwise be equivalent and thus may provide insights into the tectonic and sedimentary regime for our volcaniclastic sedimentary rocks unit.

\section{INTERMEDIATE LAVAS}

Dark, fine-grained lava flows and flow breccias (fig. 10) interbedded with volcaniclastic rocks are about $150 \mathrm{~m}$ thick in most of the mine area and approximately the same thickness in the foothills. These rocks are variably altered and are represented by diverse mixtures in drill cuttings that are difficult to interpret. Drill core and new outcrops in the deeper and eastern parts of the expanded pit provide clear exposures of flows several meters thick. The basal parts of flows are typically brecciated (flow breccia), interiors aphyric to sparsely porphyritic, and the upper parts vesicular. Flow breccia and vesicular zones tend to be highly altered: silica or sericite-pyrite close to ore, and calcite-chlorite more than about $100 \mathrm{~m}$ from ore. Some of the vesicular flows are

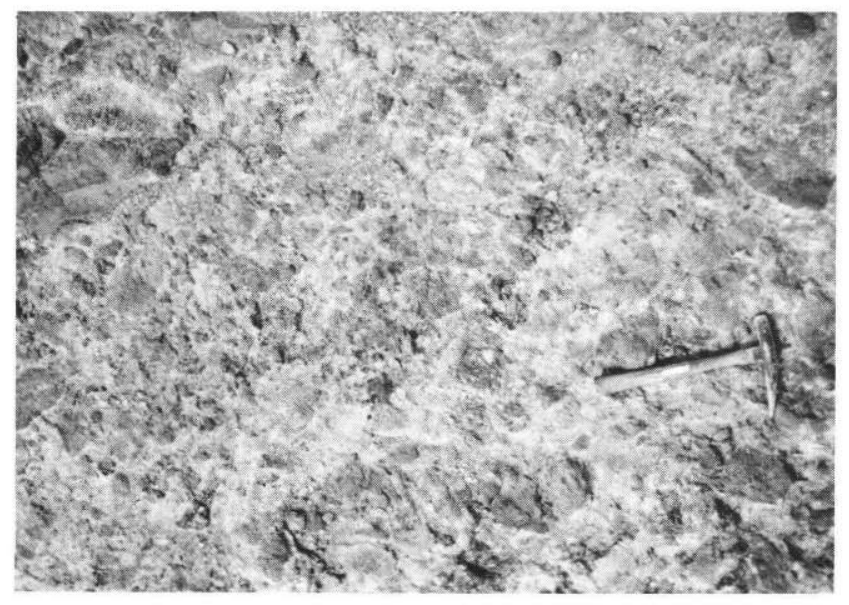

Figure 10. Flow breccia containing clasts of vesicular red and black andesite, west of ZZ-top. red, reflecting subaerial oxidation, but most are dark green. Several lithologies, described following, can be discerned megascopically and were thought to be possible stratigraphic markers, but none can be correlated for more than a few hundred meters.

The age of this unit is not known in detail. A freshappearing sample from drill core, dated by the K/Ar method, yielded an age of 14.9 Ma (Conrad and others, 1993), which is at least $2 \mathrm{~m}$.y. too young for the stratigraphic position.

Lithology. Many flows are aphyric megascopically, with fine-grained plagioclase microphenocrysts (50 to 400 $\mu \mathrm{m}$ ) in an aligned trachytic texture (fig. 11A). Vesicles are common in the aphyric flows, and generally are filled by quartz, opal, calcite, or pyrite. Mafic silicates are sparse except in one variety that contains medium-grained pyroxene, amphibole, and lesser biotite.

The pyroxene-bearing basalt lavas contain about 20 percent clinopyroxene plus hornblende phenocrysts, and 20 percent plagioclase in an aphanitic matrix (fig. 11B). Olivine phenocrysts may have been present, estimating from lightcolored alteration sites. This is the most distinctive flow in the unit and appeared to be a possible marker bed. Where observed, it lies at or near the top of the intermediate lavas unit, both in the mine area and in the foothills, but it is not present in all drill holes. Very similar pyroxene basalts crop out in the foothills. Topography of the preexisting surface, or erosion, might explain the erratic distribution of this flow within a relatively small area.

Plagioclase porphyry flows (fig. 11C) in the upper part of the section tend to resemble the Sleeper rhyolite when both are altered. The size and form of the plagioclase are similar in both units and difficult to distinguish with only a hand lens. Also, the plagioclase porphyries generally have a few round quartz "eye" phenocrysts, $0.5-1.0 \mathrm{~mm}$ in diameter, identical to the more numerous ones in the Sleeper rhyolite. Chemically and modally, these flows are dacite.

Crystal tuff appears to be erratically present in the uppernost part of the intermediate lavas, or perhaps the first eruption of the Sleeper rhyolite. Seen best in six core holes is a zone about $30 \mathrm{~m}$ thick of seemingly interbedded rhyolite, andesite lavas, and crystal tuff having quartz, plagioclase, and sanidine phenocrysts (very much like those in the Sleeper rhyolite) set in a probable tuffaceous matrix. There can be one or several layers of these tuffs and flows. Rocks with similar features are probably present in deepest parts of the Wood and Sleeper sub-pits. Alteration, in variable degree and type, obscures many features, and only thin sections provide reliable evidence on textures and composition. This zone of mixed rocks appears to reflect eruptions of slightly different material from different levels in the same magma chamber.

Chemistry. Chemical analyses show a substantial range in composition for the intermediate lavas unit (figs. 12, 13), from about 50 to 66 wt. percent $\mathrm{SiO}_{2}$, and corresponding changes in other major elements. Widespread and intense alteration negates the use of many elements ( $\mathrm{Fe}, \mathrm{Mg}, \mathrm{Ca}, \mathrm{Na}$, $\mathrm{K}$ ) for definition of rock type. Geochemical analyses (table 


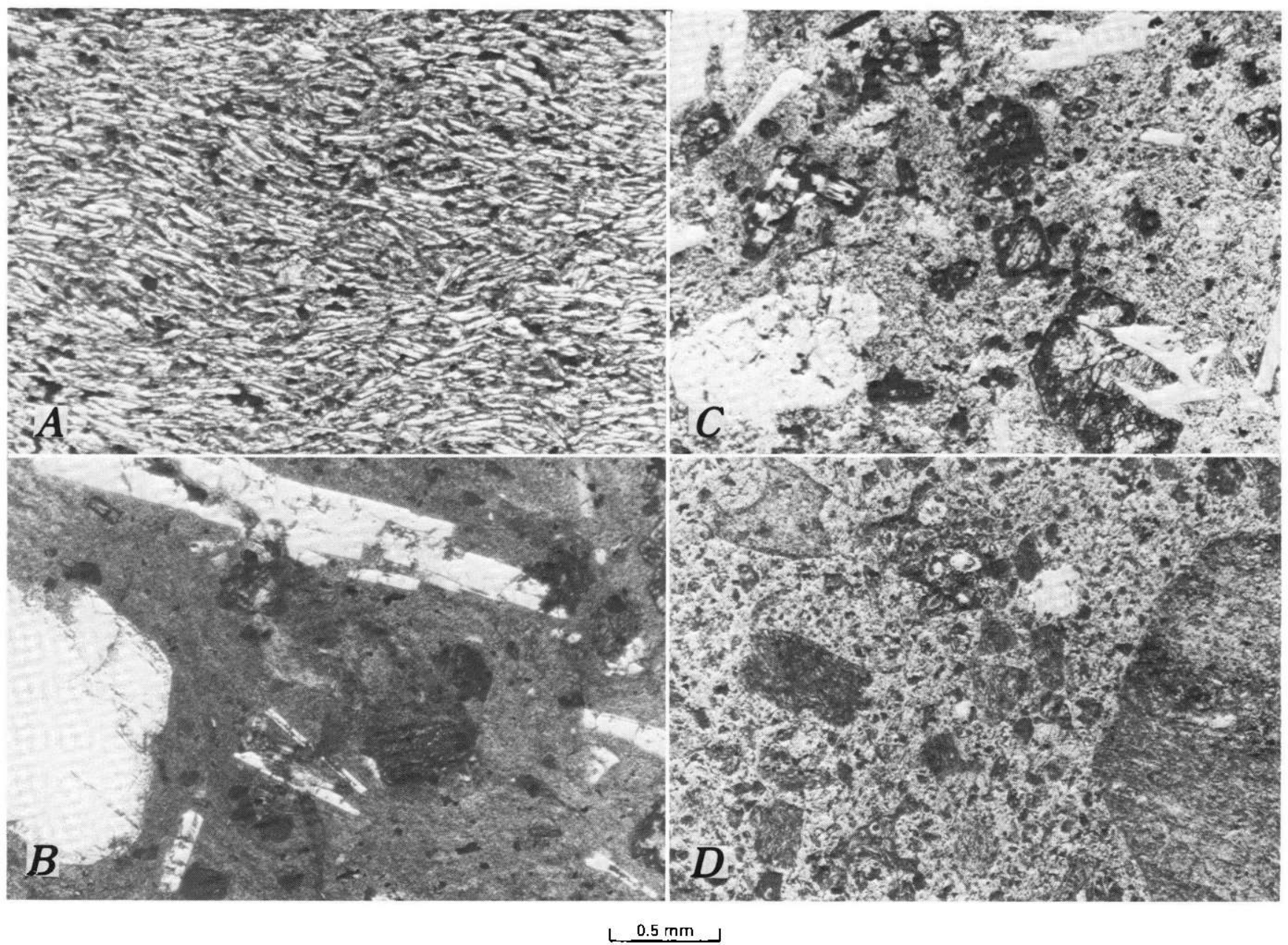

Figure 11. Photomicrographs of samples of intermediate lavas. A, Aphyric andesite flow with flow-aligned microphenocrysts of plagioclase; mafic silicate minerals are rare, but interstitial magnetite (commonly replaced by pyrite) is abundant. This characteristic texture grades into vesicular varieties. Parallel light. $B$, Porphyritic basalt flow with distinctive hornblende and augite phenocrysts and abundant magnetiteilmenite (these flows have about 2 wt. percent $\mathrm{TiO}_{2}$ ). Parallel light. $C$, Porphyritic andesite flow characterized by coarse plagioclase phenocrysts and sparse quartz "eyes" (not in photograph); aphanitic matrix is slightly recrystallized from probable glass in this atypically fresh sample. Parallel light. $D$, Lapilli tuff with coarse fragments of andesitic lithologies. Composition and size of fragments are highly variable. Parallel light.

2) indicate less than 1.5 wt. percent $\mathrm{TiO}_{2}(0.9$ wt. percent $\mathrm{Ti})$ in most of the flows, which suggests andesitic composition, as does the average content of $\mathrm{Al}\left(17.4\right.$ wt. percent $\mathrm{Al}_{2} \mathrm{O}_{3}$ ). The pyroxene-bearing flows and related dikes have a more mafic composition (up to $2 \mathrm{wt}$. percent Ti) that is basaltic. Routine analysis by ICP provides data for several relatively immobile elements (Ti, V, Sc, P; Pearce and Cann, 1973; Floyd and Winchester, 1978) that are useful for identifying these rocks relative to others in the section (fig. 9). Higher concentrations of $\mathrm{Cr}, \mathrm{Co}$, and $\mathrm{Ni}$ are typical of the flows of the intermediate lavas and probably reflect rock-forming rather than ore minerals. Concentrations of $\mathrm{Ca}, \mathrm{Na}$, and $\mathrm{Mg}$ are highly variable, reflecting alteration, but can be useful for lithologic identification because these elements are so low in Sleeper rhyolite (Nash and Bartlett, 1991). Large amounts of $\mathrm{K}$ and $\mathrm{S}$ were added during various stages of alteration. Many altered pyritic flows contain 2-5 wt. percent $\mathrm{S}$, and as much as 17 percent $\mathrm{S}$ (equivalent to 4-10 and 32 wt. percent $\mathrm{FeS}_{2}$ ).

Discussion. The intermediate lavas are mixed rocks of indistinct aspect that provide little information for regional correlation. Most likely they are local flows, emanating from numerous dikes of the same texture and composition. These flows were mostly subaerial, indicated by development of hematitic zones of oxidation. No pillow structures, indicating flow into water, have been recognized, but the lower part of the unit with its interbedded clastic rocks may have formed in an aqueous environment.

The Miocene (16.2 Ma) Steens Basalt is a widespread basaltic flow that provides a good stratigraphic marker unit in northwestem Nevada and Oregon (Rytuba and McKee, 1984). This basalt has prominent and distinctive $2 \mathrm{~cm}$ plagioclase phenocrysts. We anticipated finding this unit in the mine area, possibly as part of the intermediate lavas, but to 


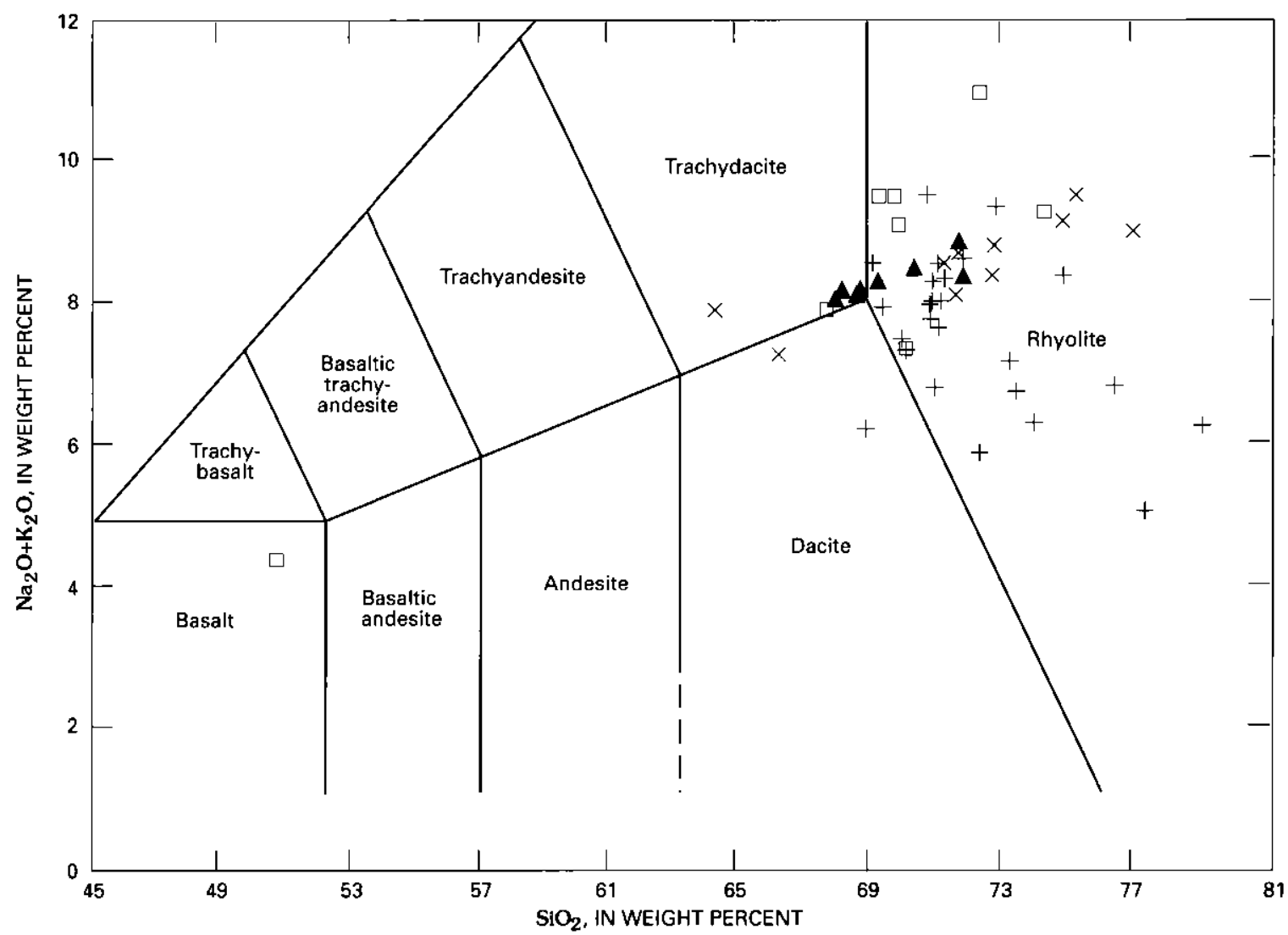

Figure 12. Total alkali-silica diagram showing the composition and classification of relatively fresh rock samples from the Sleeper mine area. Diagram from Le Bas and others (1986). Solid triangle, Awakening rhyolite; plus, Sleeper rhyolite; open rectangle, other (this study); X, McDermitt volcanic field, from Rytuba and McKee (1984); Conrad (1984).

1993 only a few pieces of float have been located in the Slumbering Hills and no rocks of this distinctive lithology have been seen in drill core, cuttings, or pit exposures. Thus, although the Steens Basalt probably is present in the area (in a thin flow?), it cannot be used to date the flows of the intermediate lavas or other rocks in the area.

\section{LAPILLI TUFF}

Distinctive rocks having centimeter-size angular fragments of light-colored pumice in a dark-gray matrix of ash or clay (fig. 14) were first observed in the east wall of the original Sleeper pit where they were bounded by faults. Other lapilli tuffs occur deeper in the Tertiary section, interbedded with andesite lavas. The coarse pumice fragments distinguish this unit, but a variety of felsic to basaltic clasts are found in the lapilli tuff (fig. 11D). The upper part of the unit grades into mostly fine grained tuff that alters to soft, greasy clay masses. Bedding observed in pit exposures and drill core is faint to massive. Core drilling returns good material of this unit, whereas reverse circulation drilling returns only mud, which is only permissive evidence for its presence. Based on core holes, the distribution of the pumice lapilli tuff is limited to the northeastern part of the mine area where it ranges from 0 to $40 \mathrm{~m}$ thick (fig. 30 C). These thickness estimates may be in error if the unit is rotated more than $30^{\circ}$ within fault blocks. Lapilli tuff is abundant in the ultimate Sleeper pit (pl. 2 ), highly faulted and sheared, and bedding is rarely seen to provide proper information on local dip.

Although contacts of lapilli tuff and the Sleeper rhyolite are faults in most places, some drill core intercepts suggest that the rhyolite was deposited on the lapilli tuff in the northeastern part of the mine area. Two drill cores show thin beds of quartz-plagioclase-sanidine crystal tuff at the top of the lapilli tuff unit, immediately below rhyolite flows. As previously described, the phenocrysts in the crystal tuff closely resemble those in the overlying rhyolite flows, which suggests that the crystal tuff, lapilli tuff, and Sleeper rhyolite are closely related in time and space, probably erupting from the same vent or vents.

Lithology. Coarse, angular lithic clasts in a fine clay (ash) matrix are distinctive (fig. $11 D$ ), but not always present in this unit. Greatest dimension of the clasts ranges from $<1 \mathrm{~mm}$ to $3 \mathrm{~cm}$. The light-tan clasts of pumice are most easily seen, but a variety of aphyric to porphyritic, dacitic to basaltic clasts are present and often mixed within a sample. The matrix clays have variable mineralogy, with illite and 


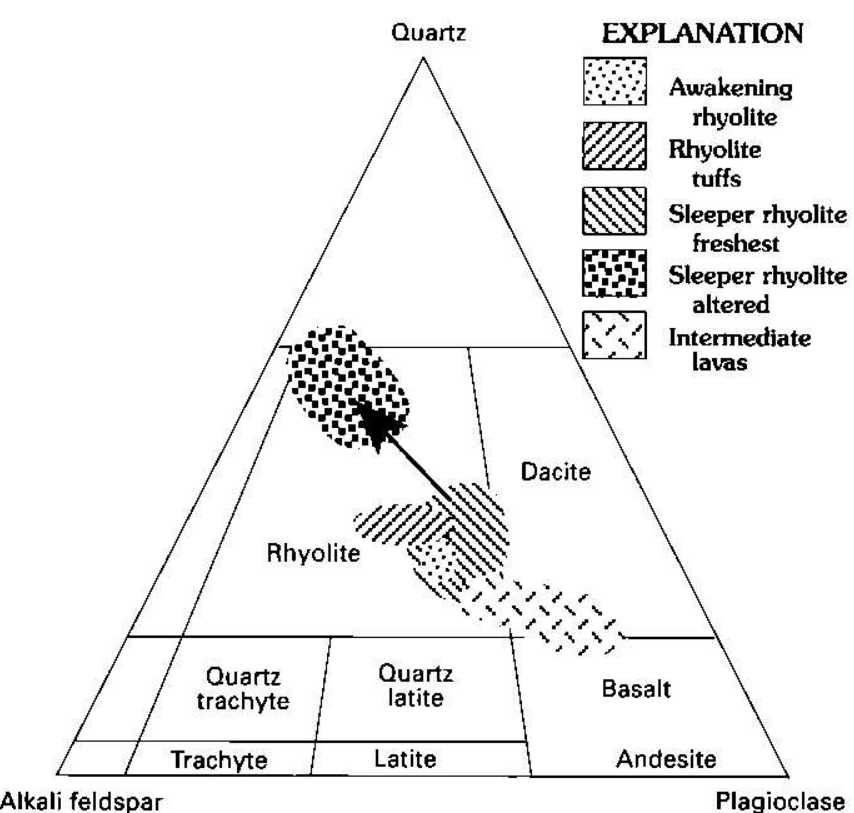

Alkali feldspar

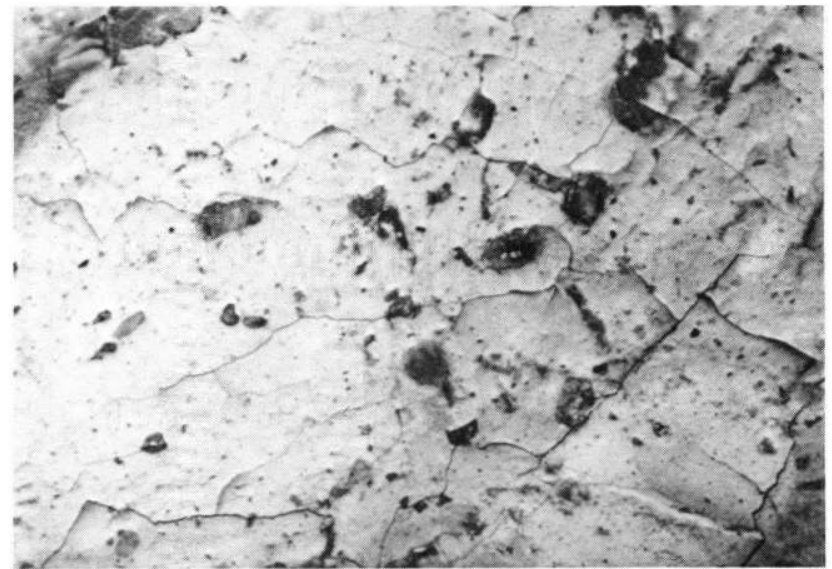

Figure 14. Lapilli tuff with 1- to 2-cm-long clasts of andesite (east wall of Sleeper pit).

is incompletely known because core holes do not exist to the northeast of the mine. However, much of the pumice lapilli tuff in the tuff ring was probably removed by erosion.

\section{RHYOLITE OF THE SLEEPER MINE (SLEEPER RHYOLITE)}

gray-green in fresh samples that contain pyrite, whereas jarosite. Tuff in the upper part of the unit is massive to weakly bedded, and generally altered to soft gray clay.

Chemistry. Chemical analyses show a wide range of composition, from about 65 to 85 wt. percent $\mathrm{SiO}_{2}$, reflecting a range in both initial composition and alteration effects. Many elements, such as $\mathrm{Ca}, \mathrm{Na}$, and $\mathrm{Ba}$, are consistently depleted in these rocks (table 2), and $\mathrm{K}$ content is high (avg. 3.9 wt. percent $\mathrm{K}_{2} \mathrm{O}$ ) and presumably added during alteration. Where these rocks are competent enough to be cut for thin sections, fragmental textures survive but are replaced by micro-quartz, sericite, and pyrite, and plagioclase-shaped forms are filled by sericite or quartz. Contents of mafic elements such as $\mathrm{Ti}, \mathrm{P}, \mathrm{Cr}$, and $\mathrm{Sc}$, which most likely were originally in rock-forming minerals, are generally much higher than in the Sleeper rhyolite and suggest a mafic to intermediate original composition. Contents of $\mathrm{Cu}, \mathrm{Co}$, and $\mathrm{Ni}$ also are high and either could attest to a mafic heritage or could reflect introduction along with the abundant sulfide minerals. The light-colored pumice fragments have the appearance of silicic pumice, an interpretation by Rytuba (1989), who obtained analyses of selected pumice pieces. Thus chemical and textural evidence suggests that the pumice lapilli tuff represents an eruptive mixture of mafic-intermediate magma and overlying fractionated silicic magma.

The lapilli tuff appears to be a local unit near a volcanic vent. It probably is part of a tuff ring erupted explosively from a nearby vent. Preserved tuff rings or cones elsewhere have diameters of 100 to $3,000 \mathrm{~m}$, and the pyroclastic deposits can be as much as $300 \mathrm{~m}$ thick (Fisher and Schmincke, 1984). The distribution of the pumice lapilli tuff
The most economically important rock unit in the Sleeper mine is the Sleeper rhyolite, which hosts more than 90 percent of known gold production and reserves. It was exposed in part of the pediment (now covered by the mill and office buildings), caps several hills east of the mine, and comprises most of the bedrock exposed in the pit. Coarse to medium ( $1 \mathrm{~cm}$ to $1 \mathrm{~mm}$ ) size phenocrysts of plagioclase, sanidine, and quartz (fig. 15) are present in consistent percentages, although some local zones have different phenocryst abundances. Hydrothermal alteration and weathering effects range from weak to intense, which can have a major influence on the macroscopic appearance of rocks and character of drill cuttings. Using phenocryst mineralogy as the key recognition criterion for the Sleeper rhyolite, we map this unit through most of the pit, in the subsurface to the westem limit of drilling (figs. 16, 17, 18), and on several hills up to $2 \mathrm{~km}$ east and $5 \mathrm{~km}$ southeast of the mine (pl. 1).

The age of the Sleeper rhyolite remains somewhat problematic despite our efforts to establish geologic relations and find samples suitable for geochronologic analysis. The Sleeper rhyolite is not in contact with the rhyolite ash-flow tuffs, well dated at 16.2 and $15.6 \mathrm{Ma}$ (Conrad and others, 1993; Rytuba and McKee, 1984). It is overlain south of the mine by unaltered Awakening rhyolite (13.6 Ma, Conrad and others, 1993); the nature of the contact cannot be established from drill cuttings, but we presume it is unconformable. The pervasive alteration of even the freshest-appearing glassy samples of the Sleeper rhyolite confounds precise dating by $\mathrm{K} / \mathrm{Ar}$ and ${ }^{39} \mathrm{Ar} /{ }^{40} \mathrm{Ar}$ methods, resetting apparent ages to ones 
younger than those of ore-stage adularia (15.5-16.5 Ma). The best estimate is about $17 \mathrm{Ma}$, or possibly somewhat older (Conrad and others, 1993).

Lithology. Distinctive, round (resorbed) quartz "eye" phenocrysts, $0.5-1 \mathrm{~mm}$ in diameter (fig. 19B, D), survive even the most intense alteration and are the most reliable guide to this unit; however, the quartz eyes can be difficult to recognize in argillized rocks using only a hand lens. Sanidine, in twinned crystals 5-10 mm long, survives most alteration. Plagioclase, with distinctive stubby shape and $1-5 \mathrm{~mm}$ size, is highly susceptible to alteration, but its morphology generally can be recognized in silica or clay minerals that replace it. Biotite or its alteration products are sparse to absent in most samples, but very fresh samples or ones from a zone near the base of the unit can have a few percent.

The groundmass, comprising about 70 percent, is generally aphanitic with 5-10 percent of elongate plagioclase microphenocrysts $0.2-0.4 \mathrm{~mm}$ long. Microphenocrysts commonly are aligned and show flowbanding more reliably than other features, such as color banding and microlites in groundmass, which are very susceptible to alteration. The groundmass in most samples is aphanitic but variably recrystallized in various types of alteration (figs. 19, 20). A continuum of groundmass textures is evident, from fresh brown glass, to partly devitrified with microlites, to aphanitic having isotropic (opaline) or faintly anisotropic (microcrystalline) silica. Dikes and sills of Sleeper rhyolite have distinctive patches of anisotropic matrix in optical continuity across $20-80 \mu \mathrm{m}$ (fig. 20D), most likely an auto-metamorphic effect.
Parts of the Sleeper rhyolite having dark, glassy groundmass (fig. 19A-C) are cut by many rotary drill holes on the western and southern side of the mineralized and altered zone, more than $120 \mathrm{~m}$ from ore (fig. 18). The vitreous intervals are estimated to be $<0.3$ to $>22 \mathrm{~m}$ thick, judging from mixed cutting lithologies in $1.5 \mathrm{~m}(5 \mathrm{ft})$ sample intervals. Several drill cores show dark-gray zones of littlealtered rhyolite several feet thick, with gradational boundaries and internal feathery streaks of light-colored alteration that appears to encroach on little-altered rock along flow foliation. These poorly exposed features are glimpses of devitrification and perlitic alteration that pervaded most of the Sleeper rhyolite. Petrographic studies suggest that opaline silicification progresses along flow foliation (fig. 20) and is essentially part of the devitrification process.

Some rare $(<1$ percent) local compositional variants have been noted in drill core and pit exposures or outcrops. Biotite (or alteration products in its place) is very rare in rhyolite of the mine area, but fresh biotite generally is present in Sleeper rhyolite bodies in the foothills. Flow-banding is locally evident in drill core and in a few pit exposures, and is fairly common in outcrops east of the mine. Monolithic breccia, probably flow breccia, is present in drill core within a few meters of the base of the unit. Some planar features suggestive of compositional banding at millimeter scale are present locally, but probably reflect variable devitrification and alteration along flow layers. All these planar structures have low dip. Vesicles may be present in a few places, but when examined in detail (such as in thin section) most appear to be acid leach voids (fig. $21 D$ ). Systematic compositional

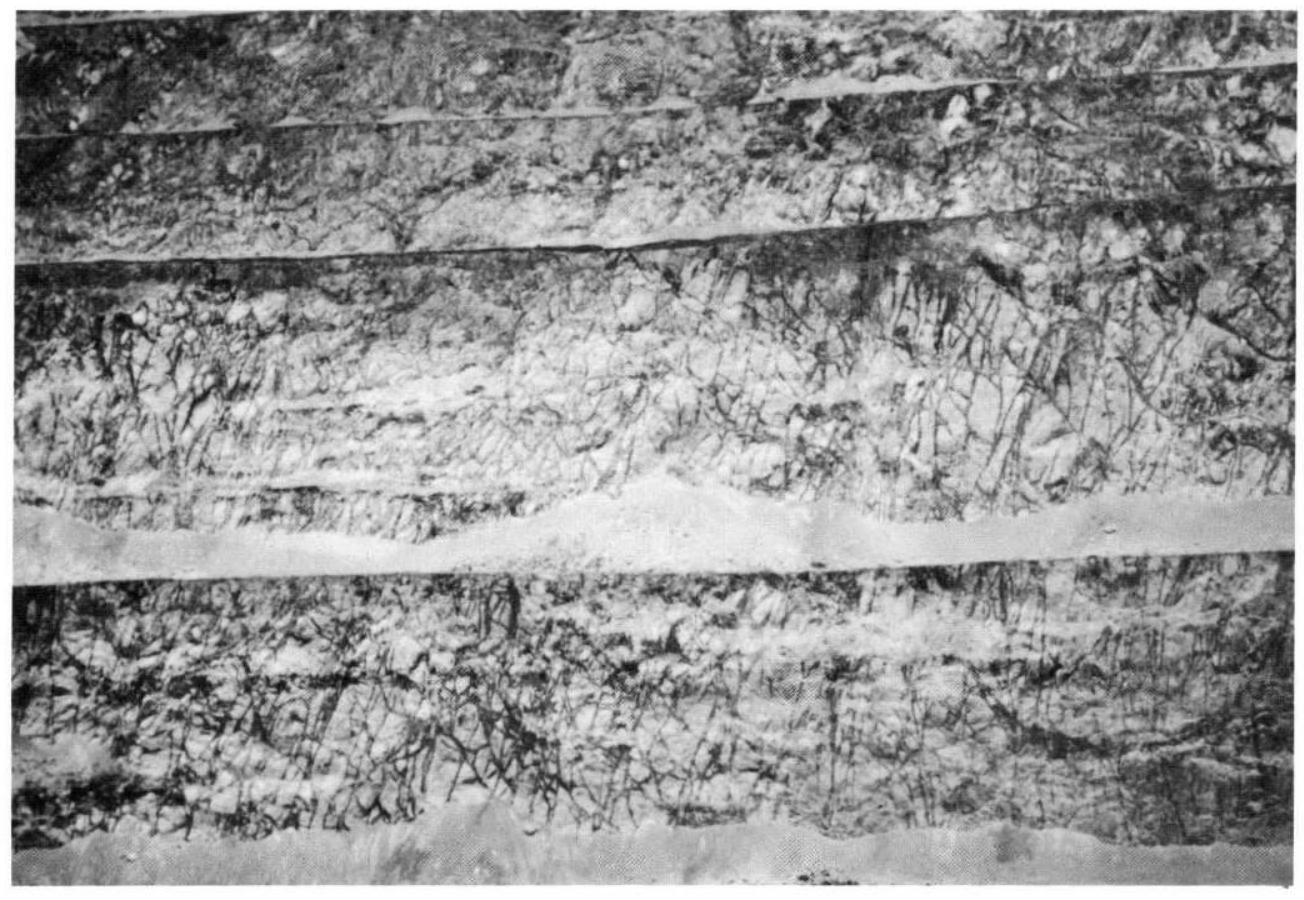

Figure 15. Sleeper rhyolite exposed on east wall of Wood sub-pit showing massive fabric cut by broadly spaced silica-pyrite veinlets (dark lines). Benches are $20 \mathrm{ft}(6 \mathrm{~m})$ high; the portion of face shown is about $36 \mathrm{~m}$ high. 


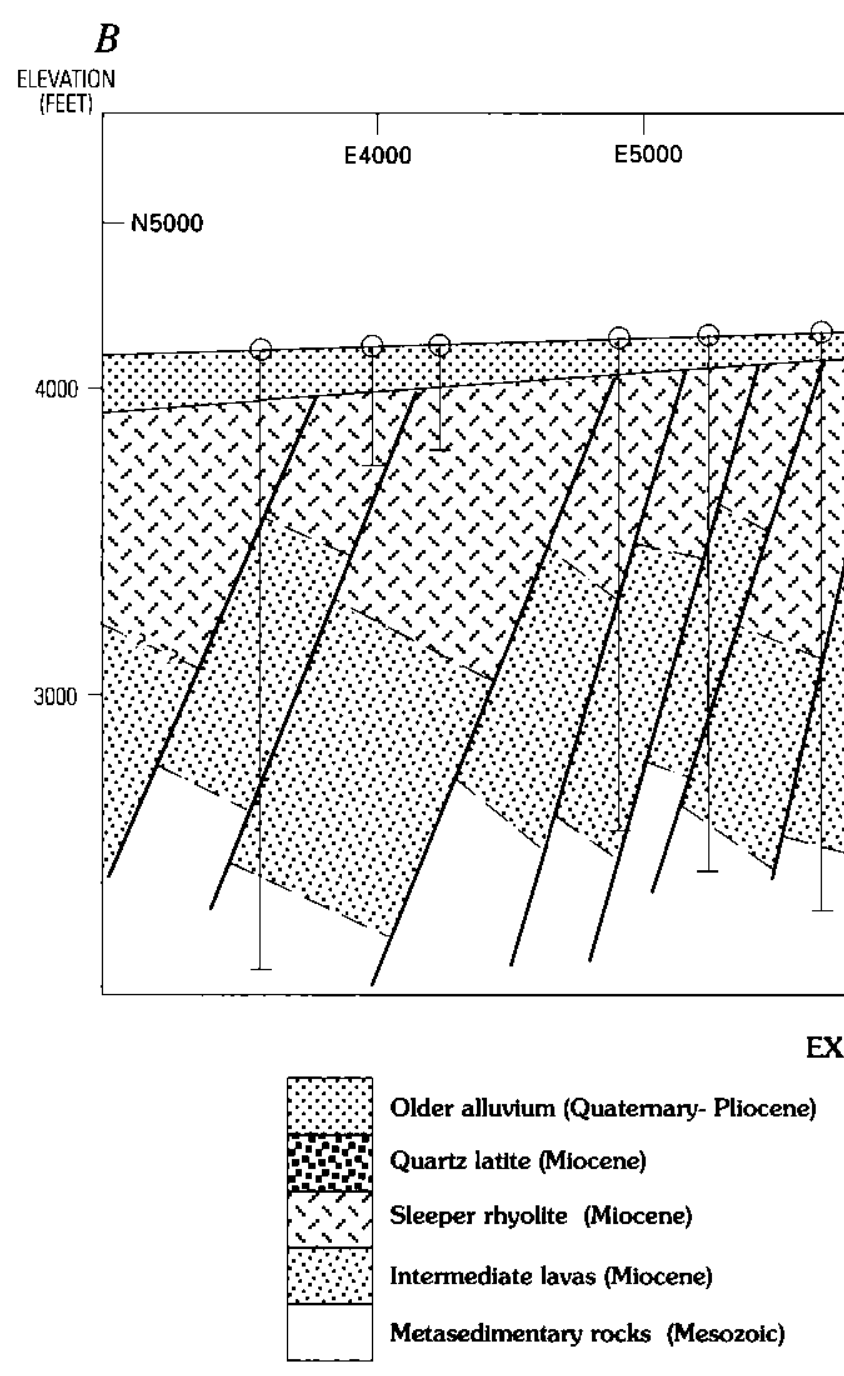

$E 6000 \quad E 8000$

Figure 16. Generalized east-west cross section $B-B^{\prime}$ of area south of Sleeper pit (5000 N), across several basin-and-range faults. Geology based chiefly on drilling information; volcaniclastic sedimentary rock unit not differentiated (included in intermediate lavas). Units queried where extent uncertain. Line of section shown on plate 1.

or textural changes within the interior of the unit, that would indicate the presence of flow or cooling units, have not been recognized but possibly were destroyed by alteration.

The basal $10 \mathrm{~m}$ of the Sleeper rhyolite tends to differ from the otherwise uniform lithology of the remainder of the unit, just described. One common difference is notable amounts (1-3 percent) of black biotite phenocrysts about 1 $\mathrm{mm}$ in size (fig. 21A). The biotite is unmistakable in thin section as dark-brown (oxidized) biotite, erratically resorbed; macroscopically and under the handlens the biotite imparts a "salt and pepper" coloration that is not seen elsewhere in the Sleeper rhyolite. Lithic fragments (xenoliths) of dark rocks (andesite and basalt) $1-3 \mathrm{~cm}$ in size are more common in this basal zone. The basal 1-3 $\mathrm{m}$ of core in what is probably the Sleeper rhyolite displays compositional and textural features that are rare or absent elsewhere: breccia and flow fabrics are common (fig. 21B), groundmass appearance changes to wispier, softer aspects that resemble tuff (fig. $21 C$ ), and phenocryst abundances are variable. Three aspects of the basal zone merit further description. (1) The breccias are generally monolithic, but some clasts are more mafic and correlate with flows of the underlying intermediate lavas. Drill core cannot show definitive lateral dimensions as in outcrop, but the breccias appear to be flow breccias, and are probably related to the flow foliation a few centimeters away. Such flow features are to be expected at the base of a lava flow. (2) The "tuffaceous" character of some basal parts probably is real (fig. $21 \mathrm{C}$ ), but flow foliation and alteration complicate textures. Shards are not evident in thin section. Many core holes penetrate about $3 \mathrm{~m}$ of "tuffaceous" material (crystal tuff having phenocrysts typical of Sleeper rhyolite), overlying 1-3 $\mathrm{m}$ of hard rock with phenocrysts and aphanitic groundmass typical of rhyolite lavas elsewhere in the mine area. The underlying rock in several holes is lapilli tuff. These features suggest local interbedding of the first rhyolite lava flows with tuffaceous material of very similar bulk composition, probably part of a tuff cone or ring. (3) Abundance of sanidine and quartz appears to be variable in the 
D

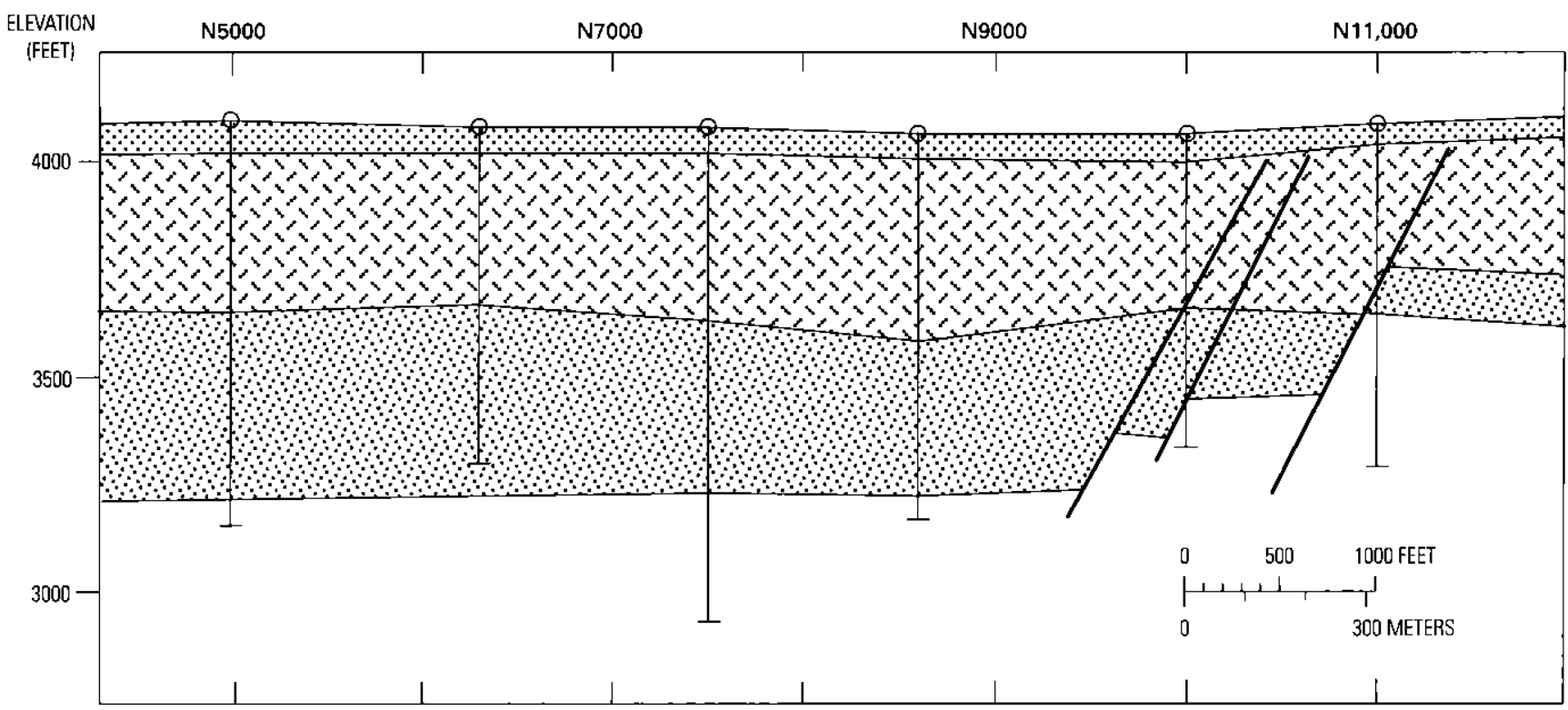

EXPLANATION
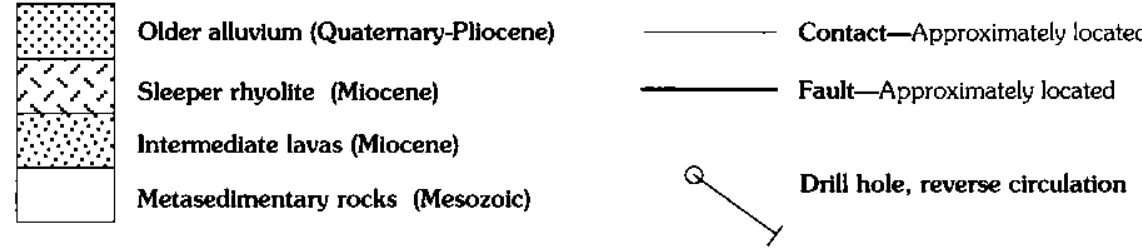

Figure 17. North-south geologic cross section $D-D^{\prime}$ through Sleeper deposit showing apparently simple layering of Tertiary lavas. Geology of deep portions is from drilling and does not permit differentiation of volcaniclastic sedimentary rock unit (included in intermediate lavas).

basal zone, although in part this may reflect inability of a thin section to provide a representative sample. Interpretation of drill core is especially difficult where Sleeper rhyolite with little or no quartz or sanidine rests on porphyritic andesite having coarse plagioclase phenocrysts (fig. $11 \mathrm{C}$ ) that are nearly identical to those of the Sleeper rhyolite. Thin flows $0.3-2 \mathrm{~m}$ thick of plagioclase porphyry (andesite) are interbedded with thin flows of Sleeper rhyolite at the base of the unit in seven drill cores. This variability may or may not be significant geologically, but it causes stratigraphic confusion when we attempt to pick the base of the Sleeper rhyolite to the closest $3 \mathrm{~cm}(0.1 \mathrm{ft})$ in core.

Geochemistry. The best estimate of the original composition of the Sleeper rhyolite (table 2 ) is from analyses of glassy samples of drill cuttings. Outcrops, mine exposures, or drill core would be preferred for the geologic information they provide, but none encountered zones with the wellpreserved glassy groundmass that was penetrated in many drill holes on the western edge of the mine area. Chips from these holes, collected for $1.5 \mathrm{~m}$ intervals, were hand picked under a binocular microscope to remove bleached, altered, or foreign chips; the low content of water $\left(\mathrm{H}_{2} \mathrm{O}^{+}\right.$reported in chemical analyses) is an indication of minor devitrification and low content of alteration products. The values reported in table 2 are normalized for water content to make them comparable to data reported elsewhere in the literature. Compositions are clearly variable: even glassy samples show variable $\mathrm{Na}$ and $\mathrm{K}$ (fig. 13), and the more visibly altered samples have highly variable compositions (figs. 22-23) in which $\mathrm{Ca}$ and $\mathrm{Na}$ are typically depleted, and $\mathrm{K}, \mathrm{Fe}$, and $\mathrm{Mg}$ are variably enriched.

Mineralogically and chemically, the Sleeper rhyolite is a normal calc-alkaline low-silica rhyolite. The least altered, glassy samples of the Sleeper rhyolite have a mean $\mathrm{SiO}_{2}$ content of 71.5 percent, which is on the low-silica end of the rhyolite class (fig. 12). Of the major elements, only potassium may be somewhat enriched, but many high values may reflect alkali exchange during early, non-ore alteration (compare fig. 22). The minor elements are not notably enriched or depleted relative to normal rhyolites. There is no geochemical evidence in Sleeper rhyolite, or the older intermediate lavas unit, for the extreme fractionation commonly seen in bimodal basalt-rhyolite sequences in continental rift zones of the world (Wilson, 1989). Relative to other Tertiary volcanic rocks of the region, the composition of the Sleeper rhyolite (table 2 ) resembles that of some post-caldera intrusions in 


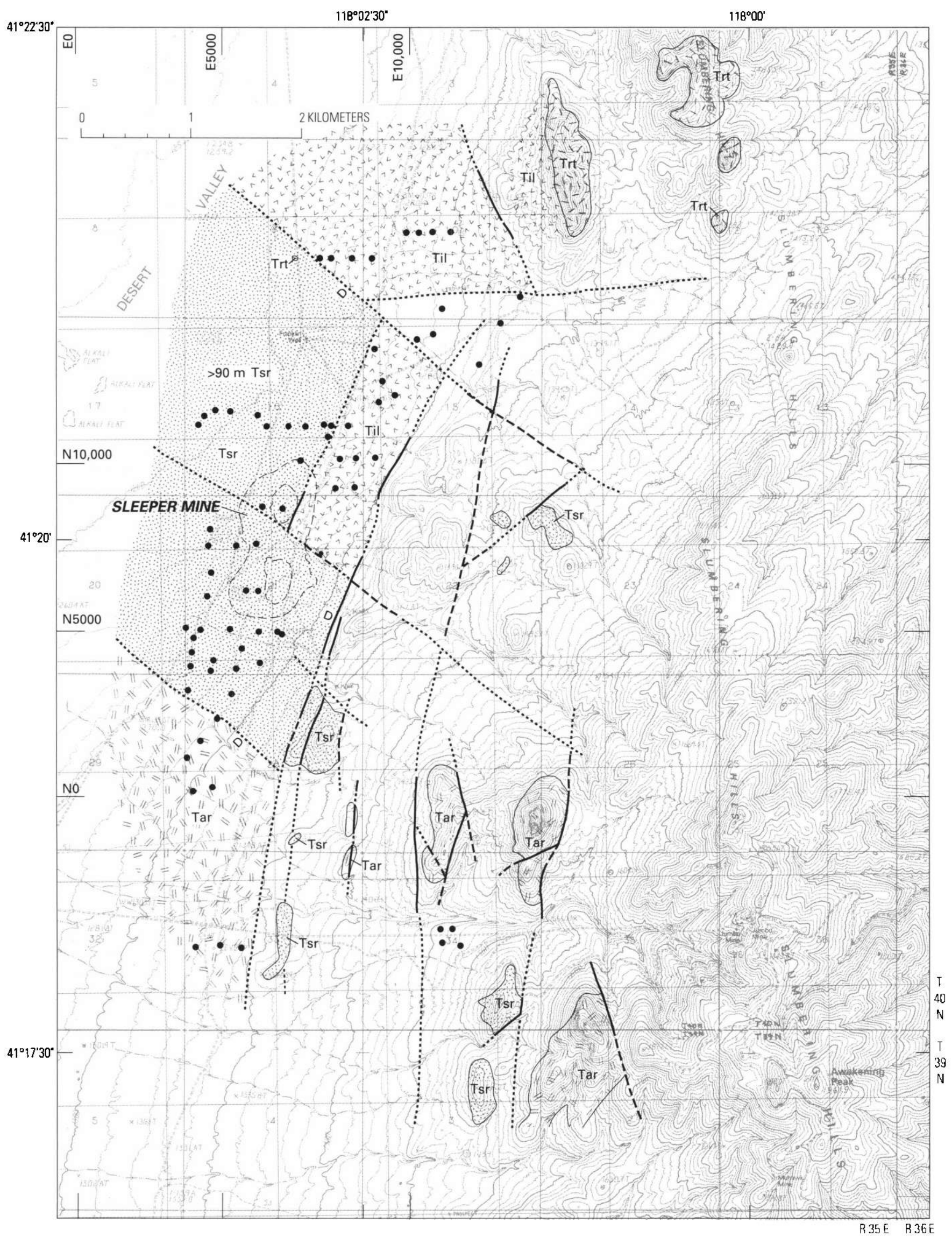


the McDermitt volcanic field, although the McDermitt intrusive rocks and especially the ash-flow tuffs have higher silica and sodium contents, and are more enriched in lithophile elements such as $\mathrm{Ce}, \mathrm{Nb}, \mathrm{Zr}$, and $\mathrm{Y}$ (Rytuba and McKee, 1984; Conrad, 1984). The mineralogy and fabric of the Sleeper rhyolite suggest that it was a dry, viscous magma when emplaced, similar to many "toothpaste" rhyolites in small intrusions and flows in the westem United States.

Sleeper rhyolite flows that crop out in the foothills have fresh to moderately altered feldspars in recrystallized or silicified groundmass. Dark-brown biotite phenocrysts, up to 3 percent, are present in samples studied petrographically. The composition of five relatively fresh outcrop samples (table 2) closely resembles that of other slightly altered samples of the Sleeper rhyolite from the mine area; compared to the glassy freshest samples of Sleeper rhyolite (table 2), $\mathrm{SiO}_{2}$ and $\mathrm{K}_{2} \mathrm{O}$ are slightly higher and $\mathrm{Na}_{2} \mathrm{O}$ and $\mathrm{CaO}$ are slightly lower. Concentrations of most minor elements are similar to those of fresh to slightly altered Sleeper rhyolite in the mine area, supporting the correlation of these rock units.

Relatively fresh appearing samples of the Sleeper rhyolite from the mine area, having fresh-appearing feldspar phenocrysts but recrystallized (nonglassy) groundmass, are chemically similar to the glassy Sleeper rhyolite (table 2) except for somewhat lower concentrations of $\mathrm{Al}_{2} \mathrm{O}_{3}, \mathrm{MgO}$, $\mathrm{CaO}$, and $\mathrm{Na}_{2} \mathrm{O}$, and higher $\mathrm{SiO}_{2}$ and $\mathrm{K}_{2} \mathrm{O}$ (figs. 22, 23). Concentrations of most minor elements are unchanged or slightly lower than in the glassy samples.

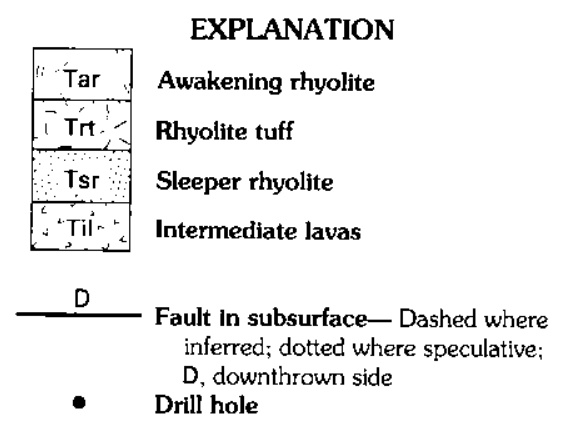

Figure 18 (above and facing page). Generalized map of subcropping and outcropping Tertiary volcanic units covered by PlioceneHolocene alluvium near Sleeper mine. Geology in foothills simplified from plate 1 . Thicknesses are minimum estimates because the tops of volcanic units are everywhere eroded. All faults are approximately located. Drill holes shown have been logged by Nash, and lithologies in many confirmed by petrographic studies. More than 1,500 reverse circulation exploration drill holes have been drilled in the area of this figure, generally on a grid of $300 \mathrm{ft}(91 \mathrm{~m})$ or less, and information from those other holes is consistent with the geology shown. Base from U.S. Geological Survey 1:24,000 Jackson Well (1982) and Awakening Peak (1982).
The Sleeper rhyolite and earlier volcanic rocks of the Slumbering Hills appear to be typical calc-alkaline igneous rocks (Irvine and Baragar, 1971) characterized by relatively high aluminum and low magnesium (fig. 23). They are peraluminous (molecular $\mathrm{Al}_{2} \mathrm{O}_{3}>$ molecular $\mathrm{Na}_{2} \mathrm{O}+\mathrm{K}_{2} \mathrm{O}$ ), in contrast to the rhyolite ash-flow tuffs erupted from the McDermitt caldera complex, described next, which are peralkaline. The Awakening rhyolite contains some probable sodic pyroxene, as in the McDermitt tuffs, but by chemical analysis is no more alkalic than the Sleeper rhyolite.

Discussion. The mode of emplacement of the Sleeper rhyolite has been difficult to establish. Some early observations suggested it was a crystal tuff or ash-flow tuff related to the McDermitt volcanic field to the north, but petrographic studies have not found features such as shards to support the tuff concept (compare Ross and Smith, 1961). Most field and petrographic features are consistent with emplacement as several flow-domes in which flows are most prominent. Most pit exposures and drill core display a homogeneous massive fabric that resembles those of intrusive rocks. Compositional layering is extremely rare. Mineral layering, caused by alignment of phenocrysts and probably caused by flow of lava, is visible in some places in the pit, and is quite common in drill core and in foothill outcrops. The flow foliation has low dips of zero to $30^{\circ}$. The geometry of the unit, especially the base, when reconstructed in cross sections, suggests that it is conformable with the unit below. Thicknesses preserved (the top is everywhere eroded) are quite uniform, about $250 \mathrm{~m}$, but possibly increase somewhat to the west (figs. 16, 17). The lateral extent is incompletely known, but may have been as wide as $6 \mathrm{~km}$ in a north-south direction and $4 \mathrm{~km}$ east-west (pl. 1). Isolated bodies of rhyolite $2-4 \mathrm{~km}$ east and southeast of the mine that have texture and composition closely resembling that of the body at the mine are probably separate flow-domes of Sleeper rhyolite. The eastern limit of the ore-bearing body may have been not much farther than the outcrops immediately east of the mine (pl. 1), but the western limit is undefined because there are no deep drill holes more than $1 \mathrm{~km}$ west of the mine in Desert Valley. The northern limit in subcrop appears to be a northwest-trending fault (fig. 18) that influenced subsequent erosion of the rhyolite. The southern limit is poorly known because of confusion with the similar-appearing Awakening rhyolite; cuttings of the two rhyolites can be reliably distinguished only in thin section. The Awakening rhyolite probably overlapped the Sleeper rhyolite south of the mine. Details of occurrence of the Sleeper rhyolite to the south in Desert Valley are not well known because most drill holes are not very deep and none yielded core. Drilling up to about $1 \mathrm{~km}$ south of the pit shows chiefly argillized quartz-feldspar porphyry with iron sulfide or iron oxides and zones of black glassy porphyry; the alteration character and phenocrysts are typical of Sleeper rhyolite. A 366-m-deep drill hole $1 \mathrm{~km}$ south of the pit showed about $230 \mathrm{~m}$ of mostly glassy Awakening rhyolite above about $90 \mathrm{~m}$ of altered rhyolite and 


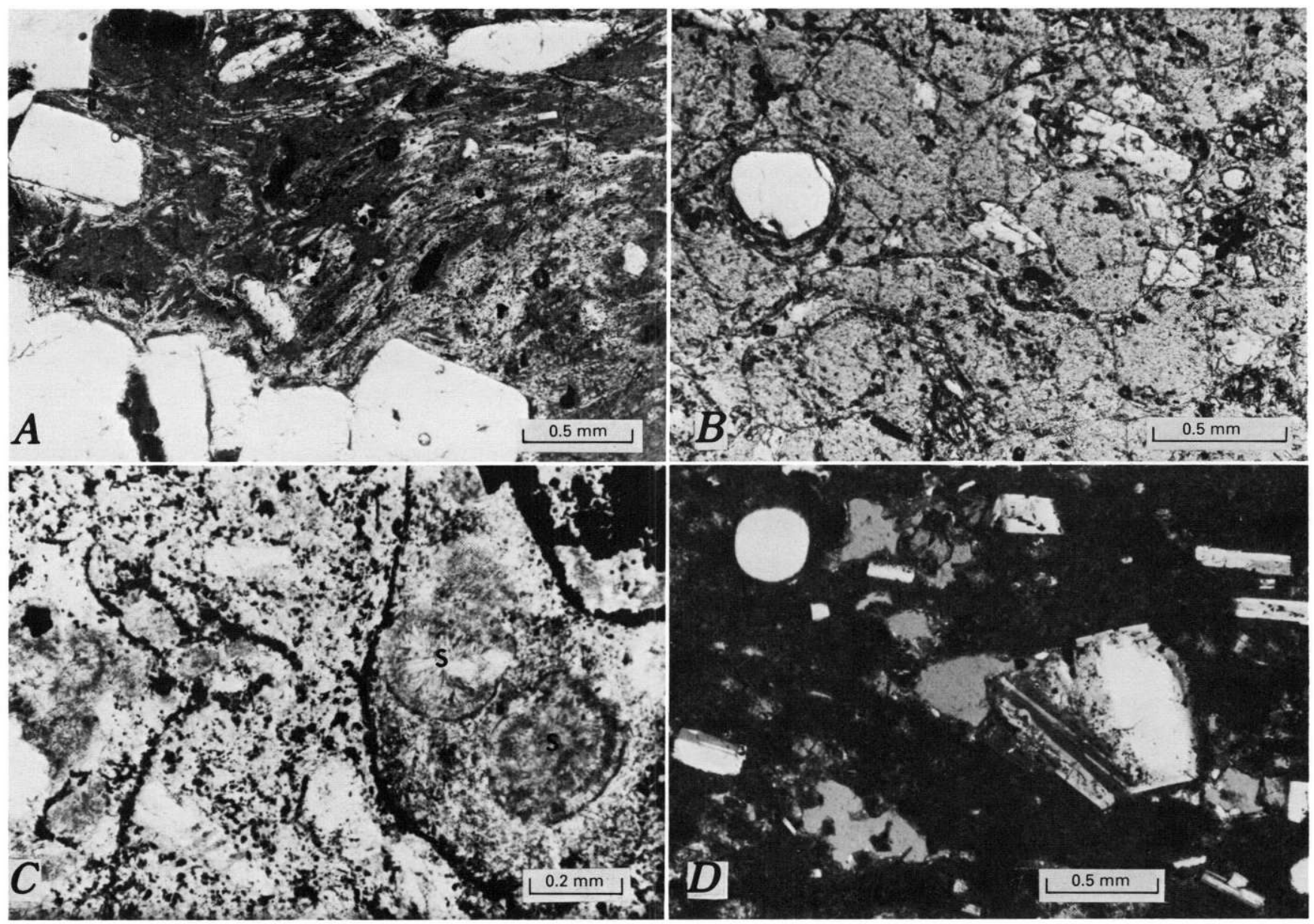

Figure 19. Photomicrographs of relatively fresh samples of Sleeper rhyolite. A, Very fresh, glassy, flow-banded plagioclase-sanidinequartz porphyry, with characteristic elongate microphenocrysts of plagioclase in groundmass. Color of glass ranges from red-brown to tan in various layers. Chip from cuttings. Parallel light. $B$, Very fresh glassy porphyry showing incipient perlitic cracks (circular cracks) and alteration. Chip from cuttings. Parallel light. $C$, Incipient alteration of glassy rhyolite to spherulites (s), and iron-sulfide minerals formed along perlitic cracks. Sample of core. Parallel light. $D$, Slightly recrystallized sample of Sleeper rhyolite. Plagioclase phenocrysts are slightly altered and aphanitic groundmass is crystallized to a faintly birefringent mass of crystallites less than $5 \mu \mathrm{m}$ in size. Crossed polarizers.

$15 \mathrm{~m}$ of intermediate lavas. The thickness of Sleeper rhyolite at the most northern and southern points of measurement in drill holes, at least $90 \mathrm{~m}$, suggests that it may continue substantially farther in those directions. Outcrops of the Sleeper rhyolite $2-4 \mathrm{~km}$ southeast of the mine (pl. 1) appear to be a feeder dike in a fault and a separate flow-dome.

The thickness, distribution (figs. 17, 18; pl. 1), and fabric of most parts of the Sleeper rhyolite body at the mine are consistent with that of a flow or flows. Flow margins and cooling units have been suspected in some drill cores and mine outcrops, but compositions and textures are generally homogeneous across large areas (although differences in alteration character may obscure primary features and make the rocks appear to be different). We have identified no interflow sedimentary rocks, and only the breccias in the basal part of the unit are flow breccias; breccias within the unit are most likely to be tectonic or hydrothermal breccias. However, several exogenous flow-domes of Sleeper rhyolite probably formed in the Slumbering Hills, best interpreted from outcrops $2-4 \mathrm{~km}$ southeast of the mine that appear to be feeder dikes and domes with steeply dipping flow-banding. As for the body at the Sleeper mine, no flow-banding with steep dips is preserved and the largest feeder dikes are only 3-21 m wide; thus we lack evidence for the central, intrusive part of this likely flow-dome complex.

Geochemical studies have greatly aided in the mapping of the Sleeper rhyolite, chiefly by defining several quantitative, objective identification criteria to augment macroscopic criteria that tended to be inconsistent and heavily influenced by alteration character. Cooperative studies by the USGS and AMAX have tested many methods and ideas for recognizing the Sleeper rhyolite, and three seem most reliable and generally applicable: (1) Macroscopic fabric: the Sleeper rhyolite is generally the most massive unit across several meters of pit face or core, composition is most uniform (with rare exceptions), and fracture intensity is highest (both silica-filled veinlets or open joints or fractures). (2) Lithology: whether 


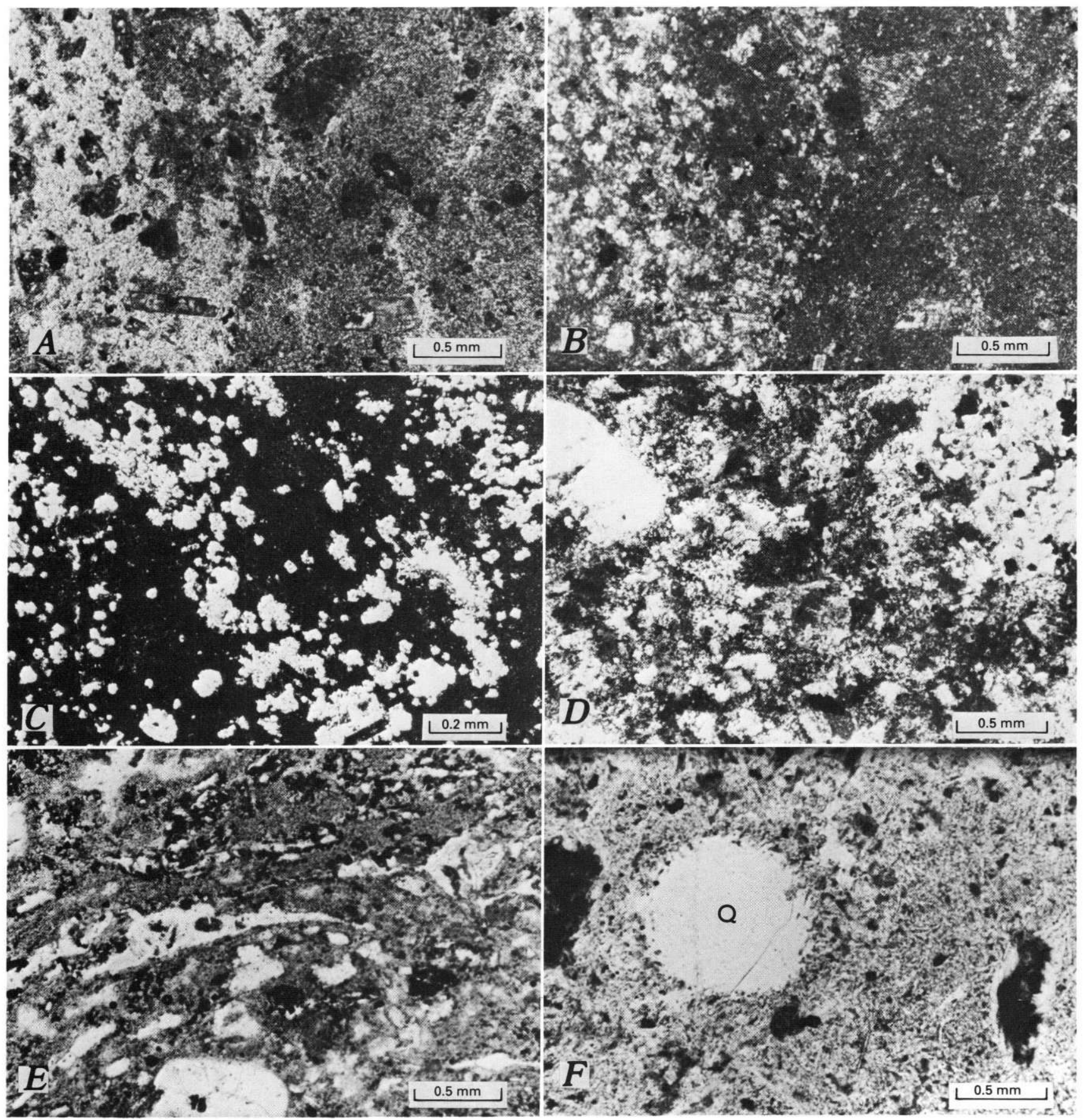

Figure 20. Photomicrographs of non-ore alteration in Sleeper rhyolite. These alteration features involving silica minerals are in pervasive zones and are considered to be transitional from devitrification to pre-ore silicification. $A$, Crystallization of glassy groundmass along flow layers; freshest groundmass in one half of photo is dark (isotropic under crossed polarizers), whereas other part is translucent (anisotropic) microcrystalline mass, possibly including silica phases. Parallel light. $B$, Same area as $A$, crossed polarizers. Glass or opal is black (isotropic). $C$, Crystallization of micro-quartz rosettes in opaline groundmass (black, isotropic). The birefringent quartz in rosettes is less than 20 $\mu \mathrm{m}$ in size. Crossed polarizers. $D$, Crystallization of groundmass in rhyolite dike to poorly organized crystallites of quartz in optical continuity across areas of more than $50 \mu \mathrm{m}$. This texture is typical of, and unique to, rhyolite dikes. Parallel light. E, Crystallization or silicification of groundmass along flow bands emphasizes primary compositional differences. The elongate, light-colored forms are micro-quartz, whereas dark colors are glass or opal. These wispy, elongate features, conspicuous in little-altered zones of drill core, have the appearance of compacted pumice. Parallel light. $F$, Lacy silica crystallites in groundmass and overgrown on quartz phenocryst (Q). The elongate quartz morphology may be caused by disequilibrium growth under supersaturated conditions as glass alters. Parallel light. 

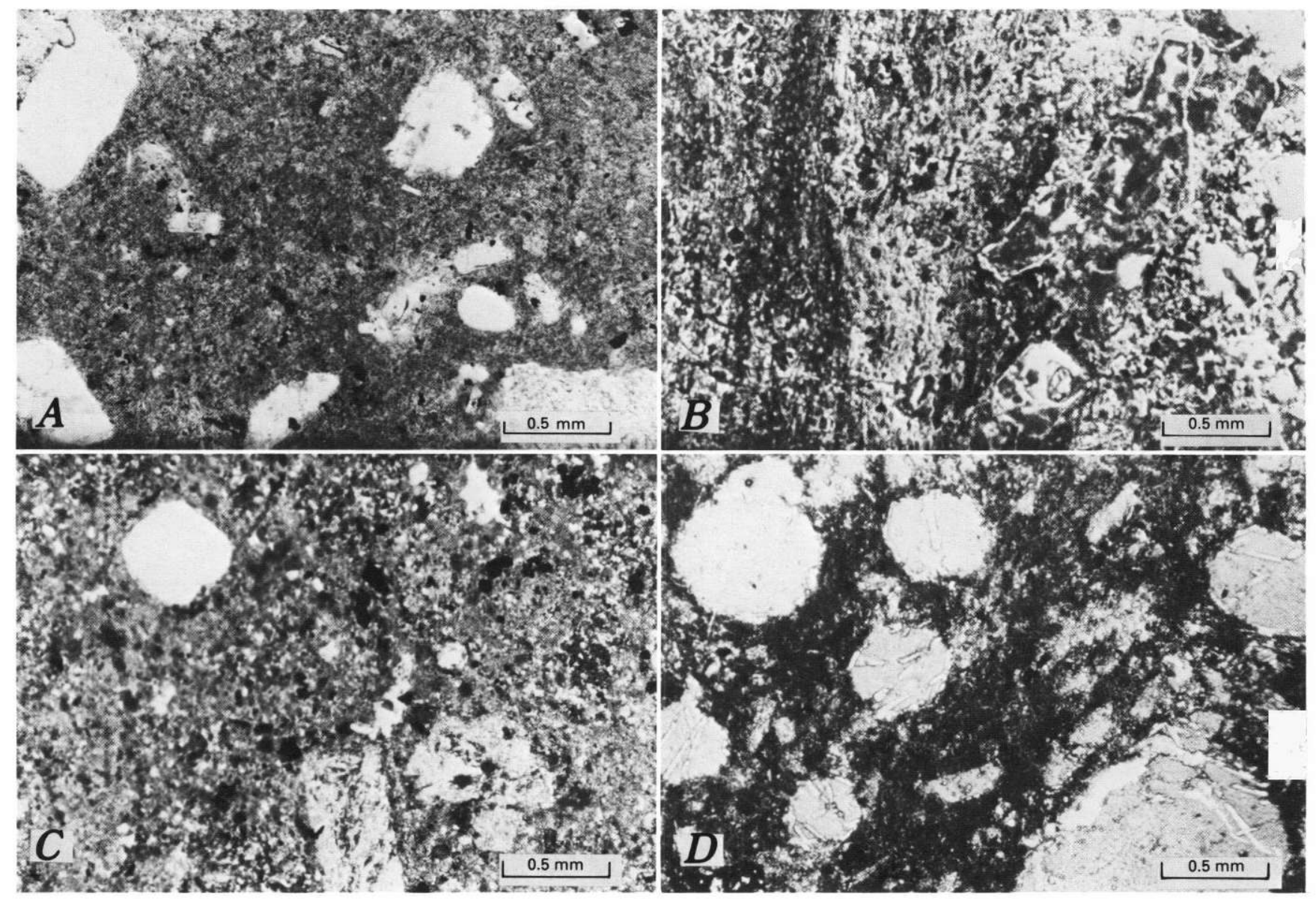

Figure 21. Photomicrographs of atypical lithologies in Sleeper rhyolite. $A$, Biotite phenocrysts in basal part of rhyolite. Parallel light. $B$, Flow-banding and flow breccia in lowermost part of rhyolite. Dips of flow bands in this core range from $20^{\circ}$ to $30^{\circ}$ (azimuth not known). Parallel light. $C$, Possible crystal tuff near base of the rhyolite. Phenocrysts are the same as in typical flows, but groundmass appears to be tuffaceous, although silica-sericite alteration obscures details (such as shards). Parallel light. $D$, Possible vesicles in rhyolite. These circular voids, filled by late-stage opal and alunite, are thought to be the result of acid leaching. Parallel light.

determined by handlens or thin section, the abundance, form, and mineralogy of phenocrysts are diagnostic, and with experience can be reliably determined independently of overprinted alteration. (3) Geochemistry: routine ICP analyses, confirmed by more specialized ones, detect a signature that is more felsic and more uniform than in other units (fig. 9): $\mathrm{Ti}$ is about $0.22-0.28$ wt. percent; $\mathrm{P}$ is $<0.10$ wt. percent; $\mathrm{V}$ is about $50 \mathrm{ppm}$; and other elements such as $\mathrm{Ce}, \mathrm{Cr}, \mathrm{Mg}$, and $\mathrm{Sc}$ are generally lower than in other units. If determined, $\mathrm{Zr}$ and $\mathrm{Nb}$ are distinctively higher than in other units (fig. 24). Uranium and Th tend to be high in rhyolite, except in highly altered zones, and these radioelements can be detected successfully by downhole gamma probes; gamma counts are roughly 100 percent higher in Sleeper rhyolite compared with underlying intermediate volcanic rocks. Geochemical analyses of drill hole samples ( $5 \mathrm{ft}$ intervals) yield generally smooth patterns for the elements mentioned in zones of the Sleeper rhyolite, whereas other units are characterized by jagged patterns reflecting compositional layering (fig. 9). The low concentrations of the mafic suite ( $\mathrm{Ti}, \mathrm{V}, \mathrm{Cr}$, and so on) and smooth pattern are very useful indicators of Sleeper rhyolite dikes.

\section{RHYOLITE ASH-FLOW TUFFS}

Peralkaline rhyolite ash-flow tuffs are as much as $80 \mathrm{~m}$ thick in outcrops $3 \mathrm{~km}$ northeast of the mine (fig. 25). These ash-flow tuffs are the southernmost known outcrops of the ash-flow tuff of Oregon Canyon and the overlying tuff of Long Ridge, both derived from the McDermitt volcanic field (J.J. Rytuba, oral commun., 1988). These tuffs have been dated at 16.1 and 15.6 Ma, respectively (Rytuba and McKee, 1984), and a sample of the lower welded tuff (ash-flow tuff of Oregon Canyon) northeast of the mine yielded $\mathrm{a}^{40} \mathrm{Ar} /{ }^{39} \mathrm{Ar}$ age of 16.2 Ma (Conrad and others, 1993). The sequence in the foothills northeast of the mine consists of (1) basal vitrophyre about $2 \mathrm{~m}$ thick and overlying white air-fall lapilli tuff about $5 \mathrm{~m}$ thick; these rocks correlate with the ash-flow tuff of Oregon Canyon (Rytuba, 1989); (2) basal vitrophyre about $1-1.5 \mathrm{~m}$ thick, airfall tuff and densely welded ash-flow tuff 
Table 2. Chemical composition of various Tertiary volcanic rocks and alteration types.

(Tsr. Sleeper thyolite; g, glassy; c, outcrop; f, relatively fresh; si, silicified; ar, argillized; Tlt, lapilli tuff (argillized); Tiv, intermediate lavas (altered); Tar, A wakening rhyolite (glassy); Trt, rhyolite ash-flow tuff. XRF, X-ray fluorescence; ICP, induction-coupled plasma spectrometry; XREDEX, energy dispersive $\mathrm{X}$-ray spectrometry; $\mathrm{FeTO}_{3}$, total iron as $\mathrm{Fe}_{2} \mathrm{O}_{3}$; leaders (--), not determined

\begin{tabular}{|c|c|c|c|c|c|c|c|c|c|}
\hline \multirow[b]{3}{*}{ Number- } & Tsrg & Tsic & Tsrf & Tsrsi & Tsrar & Tit & Tiv & Tar & Trt \\
\hline & \multicolumn{9}{|c|}{ Major elements (by XRF, normalized on volatile-free basis), in percent } \\
\hline & 13 & 5 & 19 & 26 & 33 & 21 & 21 & 3 & 4 \\
\hline $\mathrm{SiO}_{2}$ & 71.5 & 72.3 & 73.6 & 74.7 & 72.7 & 77.2 & 67.8 & 71.5 & 71.1 \\
\hline $\mathrm{Al}_{2} \mathrm{O}_{3}$ & 15.6 & 13.8 & 13.9 & 13.5 & 11.7 & 9.82 & 17.4 & 14.1 & 13.3 \\
\hline $\mathrm{FeTO}_{3}$ & 3.04 & 2.96 & 2.33 & 3.64 & 3.27 & 2.21 & 4.22 & 2.91 & 3.80 \\
\hline $\mathrm{MgO}$ & 0.52 & 0.34 & 0.24 & 0.25 & 0.33 & 0.31 & 0.50 & 0.32 & 0.33 \\
\hline $\mathrm{CaO}$ & 1.84 & 1.61 & 1.06 & 0.28 & 0.19 & 0.18 & 0.46 & 1.63 & 0.95 \\
\hline $\mathrm{Na}_{2} \mathrm{O}$ & 2.70 & 2.53 & 2.20 & 0.71 & 0.16 & 0.08 & 0.76 & 3.15 & 4.04 \\
\hline $\mathrm{K}_{2} \mathrm{O}$ & 4.43 & 4.91 & 5.17 & 4.96 & 5.22 & 3.87 & 5.44 & 5.18 & 5.12 \\
\hline $\mathrm{TiO}_{2}$ & 0.54 & 0.54 & 0.53 & 0.60 & 0.82 & 0.86 & 1.24 & 0.36 & 0.59 \\
\hline $\mathrm{P}_{2} \mathrm{O}_{5}$ & 0.11 & 0.19 & 0.15 & 0.15 & 0.21 & 0.27 & 0.52 & 0.11 & 0.14 \\
\hline $\mathrm{MnO}$ & 0.03 & 0.04 & $<0.02$ & $<0.02$ & $<0.02$ & $<0.02$ & $<0.02$ & 0.06 & 0.06 \\
\hline
\end{tabular}

Minor elements (by ICP), in parts per million

\begin{tabular}{|c|c|c|c|c|c|c|c|c|c|}
\hline $\mathrm{Ag}$ & $<2$ & $<2$ & $<2$ & $<2$ & $<2$ & $<2$ & $<2$ & -- & $<2$ \\
\hline As & $<10$ & - & 58 & 235 & 96 & 277 & 357 & - & $<10$ \\
\hline $\mathrm{Ba}$ & 1,157 & 1,456 & 1,236 & 422 & 598 & 288 & 379 & -- & 855 \\
\hline $\mathrm{Ce}$ & 62 & 66 & 63 & 48 & 60 & 41 & 47 & - & 81 \\
\hline Co & 7.2 & 3.9 & 3.5 & 8.0 & 3.2 & 66 & 15 & - & 2.5 \\
\hline $\mathrm{Cr}$ & 4.0 & 1.9 & 2.2 & 8.1 & 4.0 & 57 & 62 & - & 3.5 \\
\hline $\mathrm{Cu}$ & 9.2 & 4.2 & 4.4 & 19 & 10 & 58 & 59 & - & 8.8 \\
\hline $\mathrm{La}$ & 35 & 36 & 35 & 25 & 31 & 20 & 24 & - & 49 \\
\hline $\mathrm{Li}$ & 9.9 & 18 & 17 & 28 & 19 & 35 & 29 & - & 24 \\
\hline Mo & $<2$ & $<2$ & 3.3 & 12 & 17 & 62 & 17 & - & 2.5 \\
\hline $\mathrm{Nb}$ & 13 & 8.4 & 8.9 & 8.9 & 11 & 3.5 & 8.8 & - & 10.5 \\
\hline $\mathrm{Nd}$ & 32 & 32 & 32 & 24 & 32 & 23 & 27 & -- & 47 \\
\hline $\mathrm{Ni}$ & 3.7 & $<2$ & $<2$ & 7.3 & $<2$ & 23 & 27 & - & $<2$ \\
\hline $\mathrm{Pb}$ & 26 & 21 & 21 & 17 & 19 & 7.1 & 8.5 & -- & 19 \\
\hline $\mathrm{Sc}$ & 7.5 & 6.1 & 6.2 & 7.3 & 7.4 & 8.5 & 12 & -- & 8.5 \\
\hline $\mathrm{Sr}$ & 179 & 132 & 139 & 133 & 207 & 253 & 305 & -. & 88 \\
\hline Th & 16 & 14 & 14 & 10 & 12 & $<4$ & $<4$ & -- & 11 \\
\hline V & 31 & 21 & 22 & 47 & 33 & 89 & 123 & - & 13 \\
\hline$Y$ & 40 & 32 & 30 & 19 & 22 & 14 & 18 & -- & 48 \\
\hline$Y b$ & 4.6 & 3.6 & 3.3 & 2.2 & 2.7 & 1.2 & 1.7 & -- & 4.7 \\
\hline $\mathrm{Zn}$ & 84 & 49 & 40 & 55 & 43 & 26 & 73 & - & 111 \\
\hline
\end{tabular}

Minor elements (by XREDEX), in parts per million

\begin{tabular}{lrrrrrrrrr}
\hline $\mathrm{Ba}$ & 1,710 & - & 1,208 & 959 & 894 & 811 & 774 & - & 688 \\
$\mathrm{Ce}$ & 63 & -- & 61 & 43 & 52 & 52 & 59 & - & 81 \\
$\mathrm{La}$ & 28 & -- & 25 & 23 & 23 & 25 & 29 & - & 35 \\
$\mathrm{Nb}$ & 12 & - & 16 & 13 & 16 & 12 & 16 & - & 19 \\
$\mathrm{Rb}$ & 214 & -- & 181 & 176 & 100 & 133 & 141 & - & 126 \\
$\mathrm{Sr}$ & 158 & -- & 155 & 325 & 269 & 160 & 492 & - & 73 \\
$\mathrm{Y}$ & 47 & - & 53 & 30 & 44 & 26 & 28 & - & 57 \\
$\mathrm{Zr}$ & 258 & - & 251 & 251 & 277 & 194 & 204 & - & 412 \\
\hline
\end{tabular}



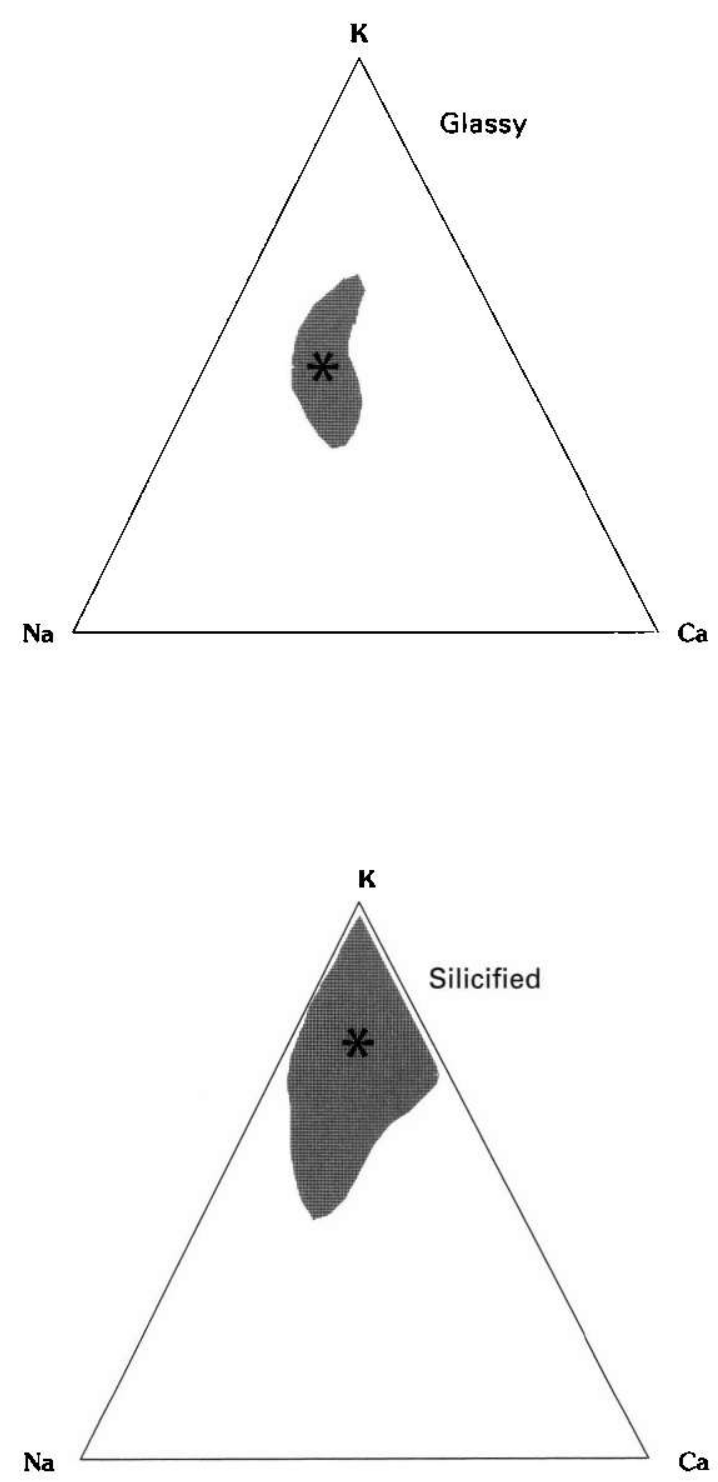
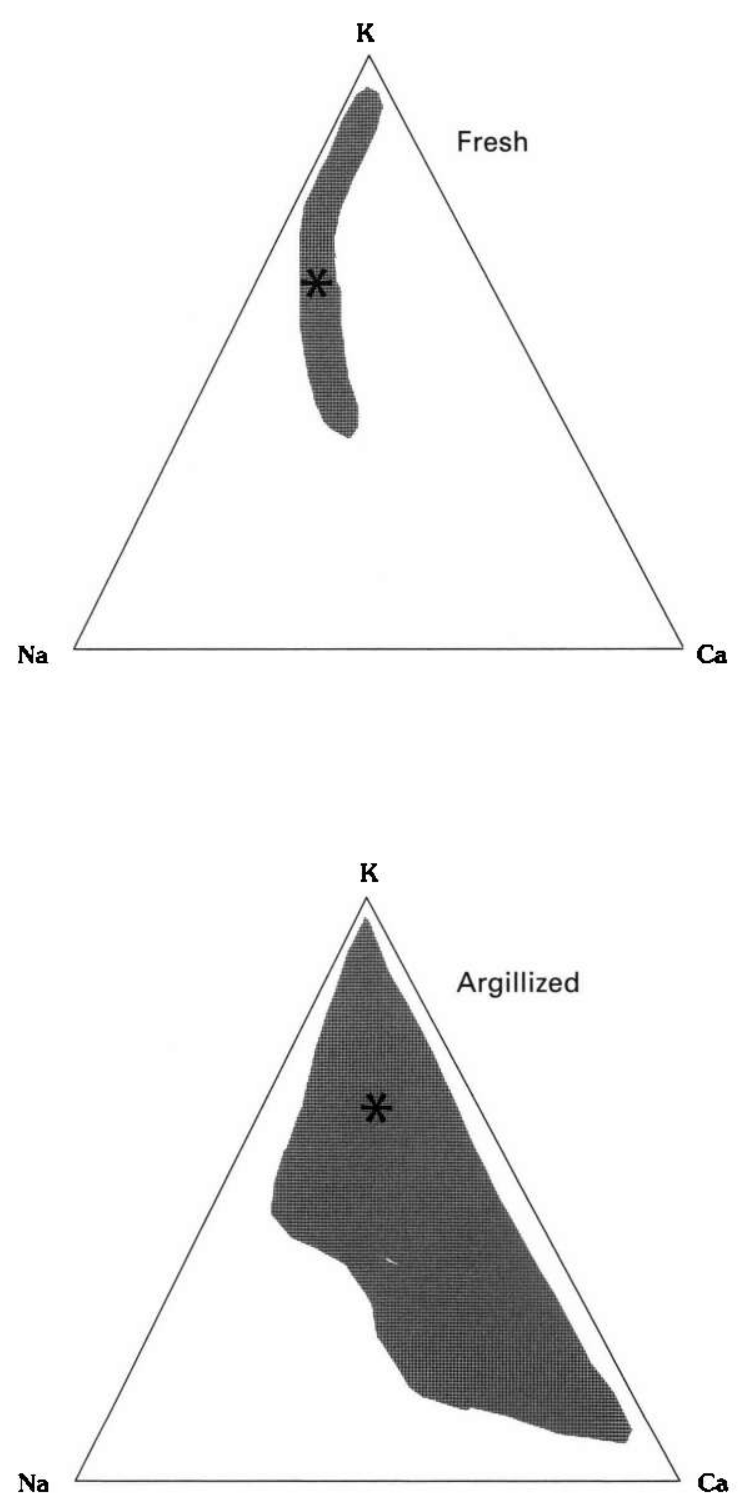

Figure 22. Chemical changes in the Sleeper rhyolite produced by alteration, shown on K-Na-Ca (percent) diagram. *, mean composition for the alteration type.

more than $20 \mathrm{~m}$ thick, which correlate with the tuff of Long Ridge (Rytuba, 1989). Lithologic and chemical features of these tuffs and vitrophyres indicate peralkaline composition and strong similarity to the units $30 \mathrm{~km}$ to the north.

Lithology. Several distinctive lithologies characterize the rhyolite ash-flow section. The most common unit in outcrop is the resistant tuff of Long Ridge (Rytuba and McKee, 1984; Conrad and others, 1993), which has the general appearance of a quartzite, but has notable platy fabric from vapor phase crystallization. In thin section untwinned alkali-feldspar is prominent in equant $200-400$ $\mu \mathrm{m}$ interlocked grains (fig. 26), as is the 5 percent of bluegreen sodic amphibole that imparts the pale-gray-green color to the rock. The extreme heat of these ash-flows produced unusually dense welding and rheomorphic folds in the upper part of the tuff of Long Ridge. Basal vitrophyres are jet black and contain about 15-20 percent feldspar phenocrysts; feldspars in the vitrophyre of the ash-flow tuff of Oregon
Canyon unit are chatoyant anorthoclase (J.J. Rytuba, oral commun., 1988). Air-fall tuffs are weakly bedded, white, friable, clay-rich rocks.

Chemistry. Analyses of the rhyolite ash-flow tuffs (vitrophyres and welded tuff) show them to be rich in $\mathrm{SiO}_{2}, \mathrm{Na}$, and many trace elements (table 2). On the alkali-silica diagram (fig. 12) these samples plot as rhyolites and overlap the data for the rhyolite of the Sleeper mine and Awakening rhyolite. Their unique peralkaline character is only shown in normative or other computations that reveal an excess of alkalis relative to $\mathrm{Al}$ on a molecular basis. The rhyolite ashflow tuffs are only mildly peralkaline (Conrad, 1984), and are not extreme relative to other rhyolites of the area or in the manner of classic peralkaline localities of the world (Wilson, 1989) when shown on a triangular diagram (Irvine and Baragar, 1971). Analytical results for samples from the Slumbering Hills agree closely with those for the type areas 

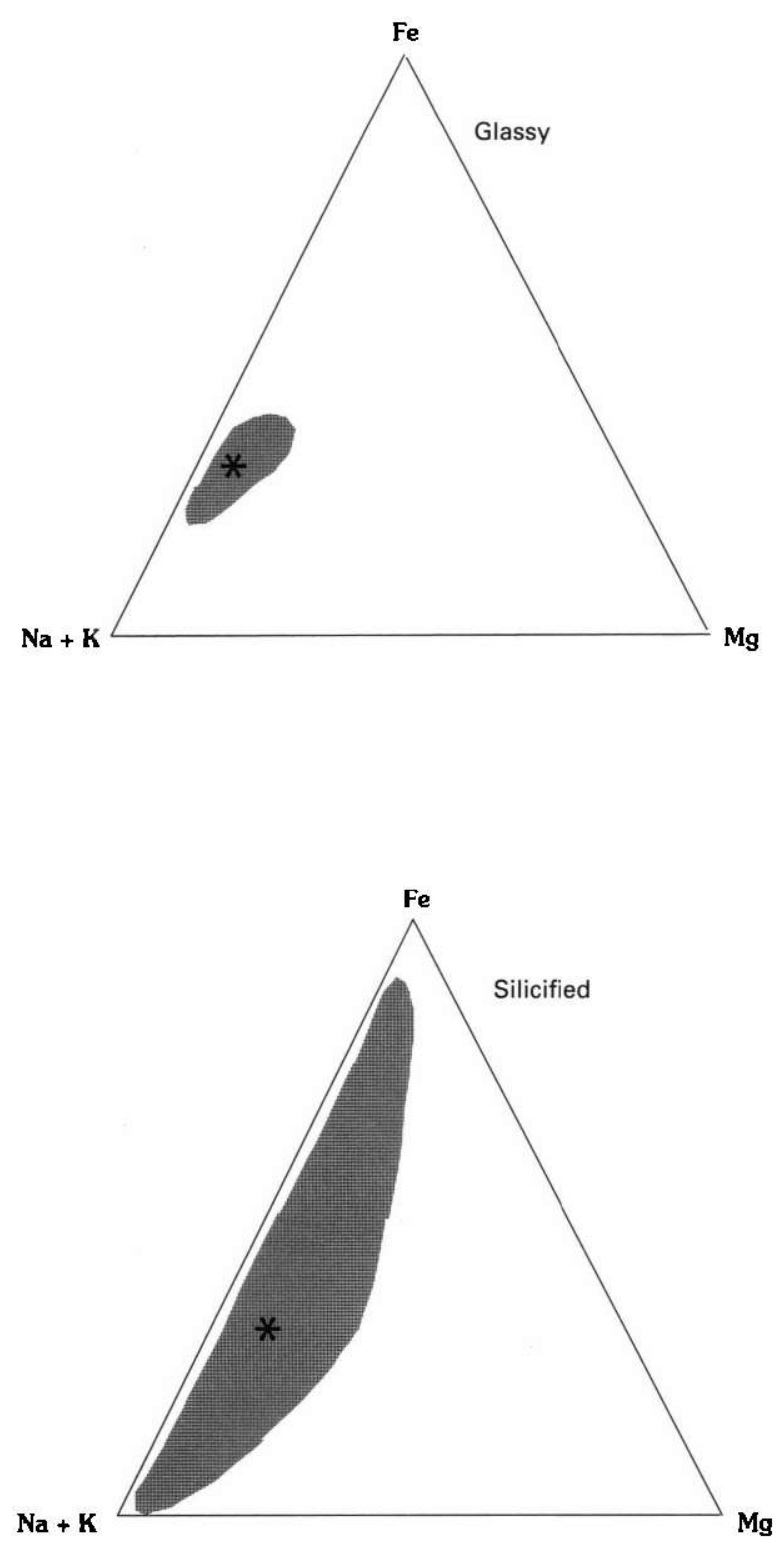
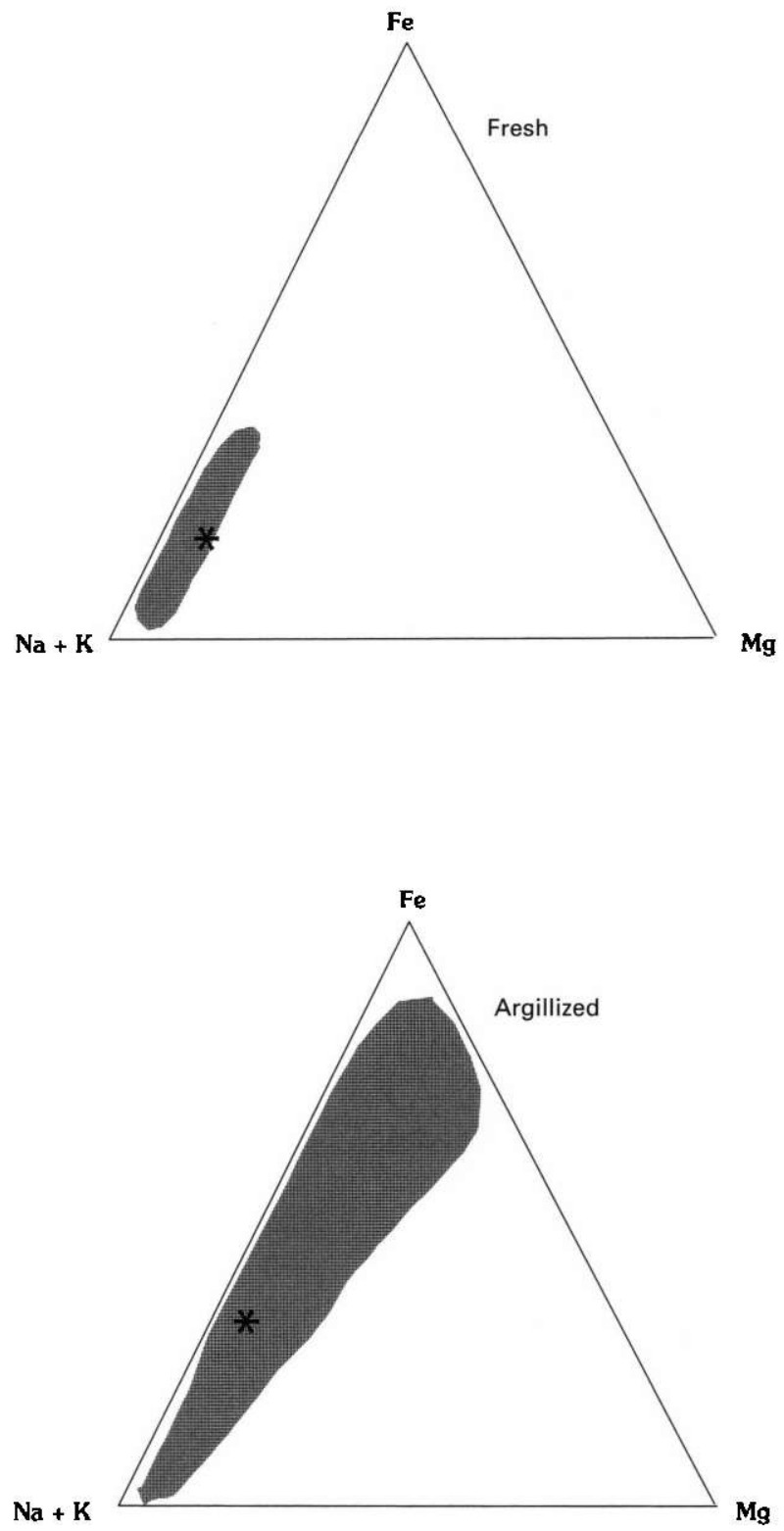

Figure 23. Chemical changes in Sleeper rhyolite produced by alteration, shown on Fe-Mg-alkali (percent) diagram. *, mean composition for the alteration type.

in the McDermitt volcanic field (Rytuba and McKee, 1984; Conrad, 1984), notably the high $\mathrm{Na}$ and $\mathrm{Ti}$, high trace elements such as $\mathrm{Zr}, \mathrm{Ce}$, $\mathrm{La}$, Th, and $\mathrm{Y}$, but low $\mathrm{Ba}$, and $\mathrm{Sr}$ relative to other rhyolites of the area.

Discussion. Rocks having the texture and composition of the rhyolite ash-flow tuffs have not been identified in the Sleeper mine despite special scrutiny. Rocks tentatively correlated with the rhyolite ash-flow tuffs have proven to be atypically fresh aphyric basalt flows or Sleeper rhyolite when examined in thin section. Reexamination of drill cuttings in 1992, combined with thin section study of selected cuttings disclosed one intercept of Long Ridge welded tuff in the subsurface about $2 \mathrm{~km}$ north of the Sleeper pit (fig. 18). No cuttings from the 183 -m-deep hole resembled the Sleeper rhyolite, and the closest recognized intercept is more than 500 $m$ to the south; thus no age relations of these units can be inferred. A 366-m-deep drill hole $1 \mathrm{~km}$ south of the Sleeper pit, drilled in 1993 and logged by Utterback, encountered units that strongly resemble tuff of Long Ridge, but petrographic study of chips show them to be unusual hematitic varieties of Awakening rhyolite and intermediate lavas. Despite the lack of positive evidence, we suspect that rhyolite tuff probably did originally cover the Sleeper rhyolite in the mine area.

Early (1988) observations of a small pit exposure and some blast float having "collapsed pumice" and trace element chemistry resembling the tuff of Long Ridge (Rytuba, 1989) have not been confirmed in new mine exposures and drill core in the northeast comer of the Sleeper pit. Our petrographic study of the "collapsed pumice" suggests microcrystalline quartz filling gash fractures 


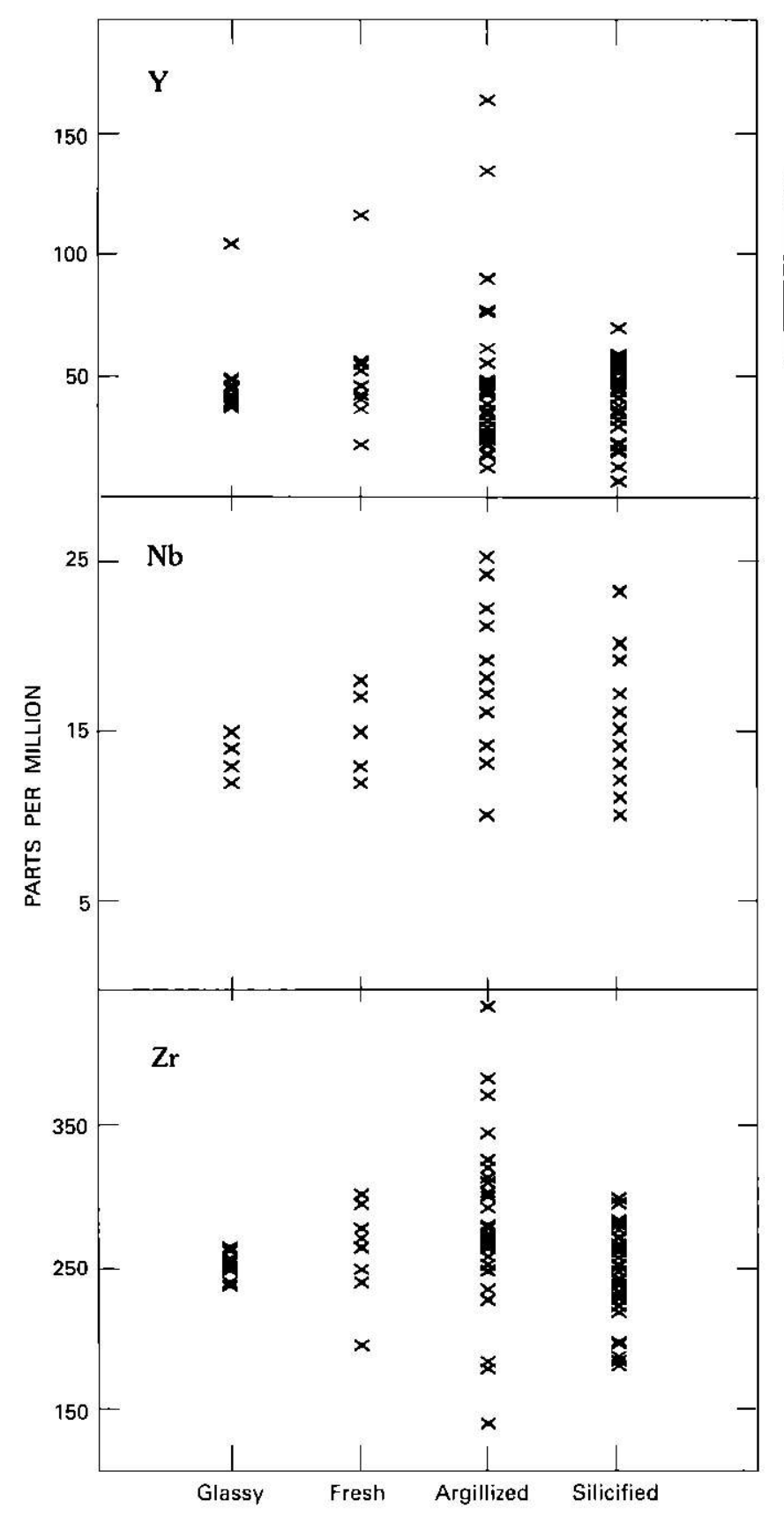

Figure 24. Abundance of $\mathrm{Zr}-\mathrm{Nb}-\mathrm{Y}$ in fresh and altered Sleeper rhyolite.

in aphyric andesite. That northeast mine area contains only andesite and basalt flows and minor volcaniclastic sedimentary rocks of the intermediate lavas, and Sleeper rhyolite. The Sleeper rhyolite-intermediate lavas contact commonly is a fault, but in places appears to be depositional. Rocks on both sides of this contact have been examined with extreme care and sampled for thin sections and geochemistry in an effort to locate a rhyolite ash-flow tuff, but we have not been successful to date (1993).

The rhyolite ash-flow tuffs are considered to be slightly younger than the Sleeper rhyolite (Nash and Bartlett, 1991).

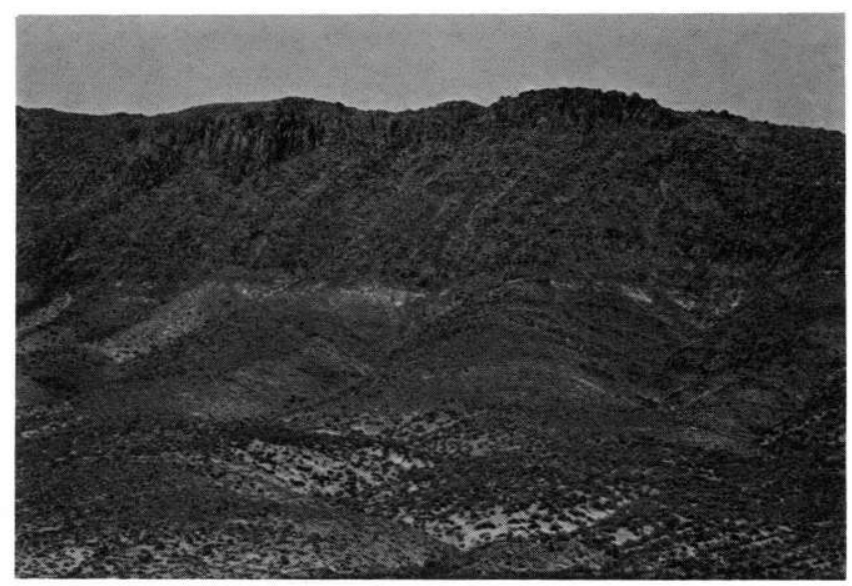

Figure 25. Rhyolite ash-flow tuffs exposed on hogback $4 \mathrm{~km}$ northeast of Sleeper mine. White zone in mid-view is airfall tuff in ash-flow tuff of Oregon Canyon, and the upper part to the skyline is the welded tuff of Long Ridge.

These two units have not been seen in contact: the Sleeper rhyolite is not exposed in the foothills northeast of the mine, and the rhyolite ash-flow tuffs are known to occur in only one drill hole about $2 \mathrm{~km}$ north of the Sleeper mine. We project the rhyolite ash-flow tuffs above the (eroded) top of the Sleeper rhyolite. Our current (1993) geologic projections, and geochronologic studies (Conrad and others, 1993), suggest that the period of ore formation overlapped, and continued after, emplacement of the rhyolite ash-flow tuffs.

Despite the close similarity in age of the rhyolite ashflow tuffs to the Sleeper rhyolite and Sleeper ore, the rhyolite ash-flow tuff eruptions were unrelated events. The rhyolite ash-flow tuffs were erupted from calderas in southeast Oregon, about $80 \mathrm{~km}$ to the north. The tectonic and volcanic setting of the calderas and rhyolite ash-flow tuffs has little in common with the Sleeper area. Those volcanic phenomena should not be included in a genetic model for Sleeper beyond their indications of regional bimodal volcanism and high heat flow, which are more directly indicated by other evidence in the Slumbering Hills.

\section{QUARTZ LATITE}

Several bodies of altered Miocene quartz-plagioclasesanidine porphyry occur between the Sleeper mine and the Jumbo mine (pl. 1). The largest body has a steeply dipping intrusive contact with metasedimentary rocks and is in fault contact with glassy Awakening rhyolite. Quartz-sericite alteration is pervasive, and probably was accompanied by pyrite, now iron oxides. Dikes of similar altered quartz latite are scattered through the foothills, generally filling northstriking normal faults.

Lithology. Relict plagioclase phenocrysts are about 1 $\mathrm{mm}$ long, as are sanidine phenocrysts, which are little altered. Round quartz eye phenocrysts are variably present, 


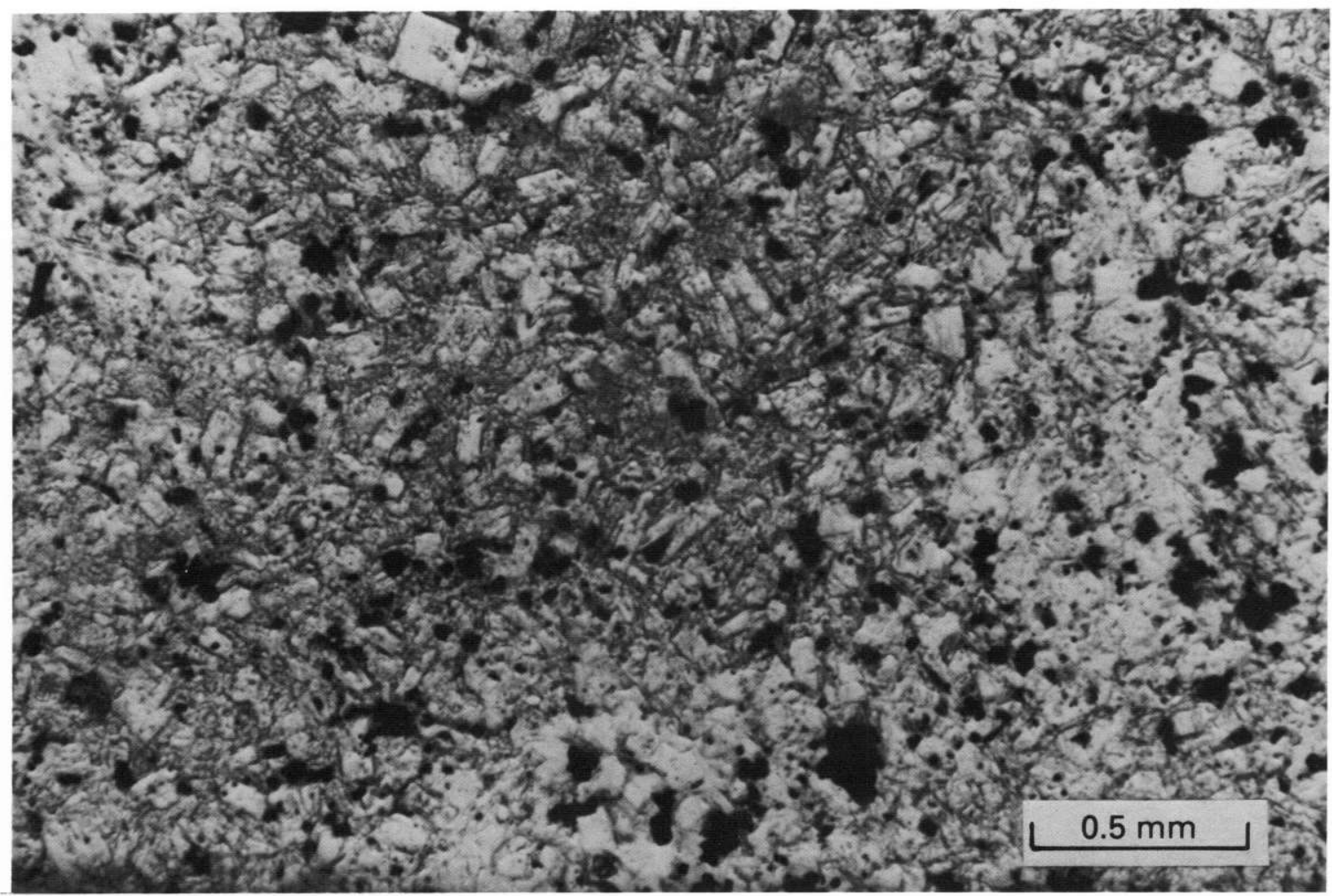

Figure 26. Photomicrograph of sample of welded ash-flow from tuff of Long Ridge. The granophyric texture in groundmass was produced during welding. Sample is pale blue gray from small amounts of sodium reibeckite. Parallel light.

ranging up to about 5 percent. Sparse pseudomorphs of mafic minerals are occupied by iron oxides and clay minerals. The groundmass, now a fine-grained mixture of quartz and sericite, probably was aphanitic or glassy.

Chemistry. Chemical analyses of two altered samples show an average (anhydrous basis) of 72.6 percent $\mathrm{SiO}_{2}$, 13.8 percent $\mathrm{Al}_{2} \mathrm{O}_{3}, 1.6$ percent $\mathrm{Fe}_{2} \mathrm{O}_{3}$ (total $\mathrm{Fe}$ ), 1.3 percent $\mathrm{CaO}, 2.1$ percent $\mathrm{Na}_{2} \mathrm{O}, 7.1$ percent $\mathrm{K}_{2} \mathrm{O}$, and 0.35 percent $\mathrm{TiO}_{2}$. The concentrations of relatively immobile elements such as Ti suggest a generally felsic original composition, hence the name "quartz latite."

Discussion. The only large body of quartz latite is near the Jumbo mine, but numerous small dikes are scattered through the area. The large intrusion appears to flare outward and has steeply dipping foliation, as in a dome. The pervasive alteration indicates that it must be older than the adjacent unaltered Awakening rhyolite. Several prospect pits and shafts in altered quartz latite demonstrate exploration activity at various times over the years. The alteration and location close to Jumbo attracted Calkins' interest (1938) for a possible role in forming the gold-adularia veins. The alteration and composition of the body suggest that it may be related to the Sleeper rhyolite. Dikes of altered quartz latite occur in the hill $0.5 \mathrm{~km}$ east of the Sleeper mine; several prospects occur in these dikes.

\section{RHYOLITE OF AWAKENING PEAK (AWAKENING RHYOLITE)}

The western flank of the Slumbering Hills, 3-6 km southeast of the mine, is capped by rhyolite flows (fig. 27) about $150-190 \mathrm{~m}$ thick, herein called the Awakening rhyolite. The thick flows, which lie unconformably on Mesozoic metasedimentary rocks and disconformably on the intermediate lavas, create craggy outcrops. A sample from the upper part of the peak known informally as ZZ-top yielded a $\mathrm{K} / \mathrm{Ar}$ date of $13.6 \pm 0.7 \mathrm{Ma}$ (Conrad and others, 1993). Fresh, glassy rhyolite extends to within $100 \mathrm{~m}$ of adularia-goldquartz vein prospects in phyllite on the south edge of the Jumbo mine area. The rhyolite projects over the prospects and Jumbo mine, but has been eroded. Calkins (1938) noted (and we concur) that the fresh state of the lavas indicates that they are younger than the Jumbo ore.

Flow-banding is generally well developed in Awakening rhyolite; in general its dip is $30^{\circ}-60^{\circ} \mathrm{E}$. The dips appear to reflect tilt in most places, but in places it reflects rheomorphic folding. Feeder dikes of glassy and altered rhyolite are present at eight localities. A basal sparsely phenocrystic vitrophyre $1-2 \mathrm{~m}$ thick is developed in many places, but no crystal tuffs of a tuff cone have been recognized. The Awakening rhyolite appears to have formed several flow-domes along normal faults. The good exposures 


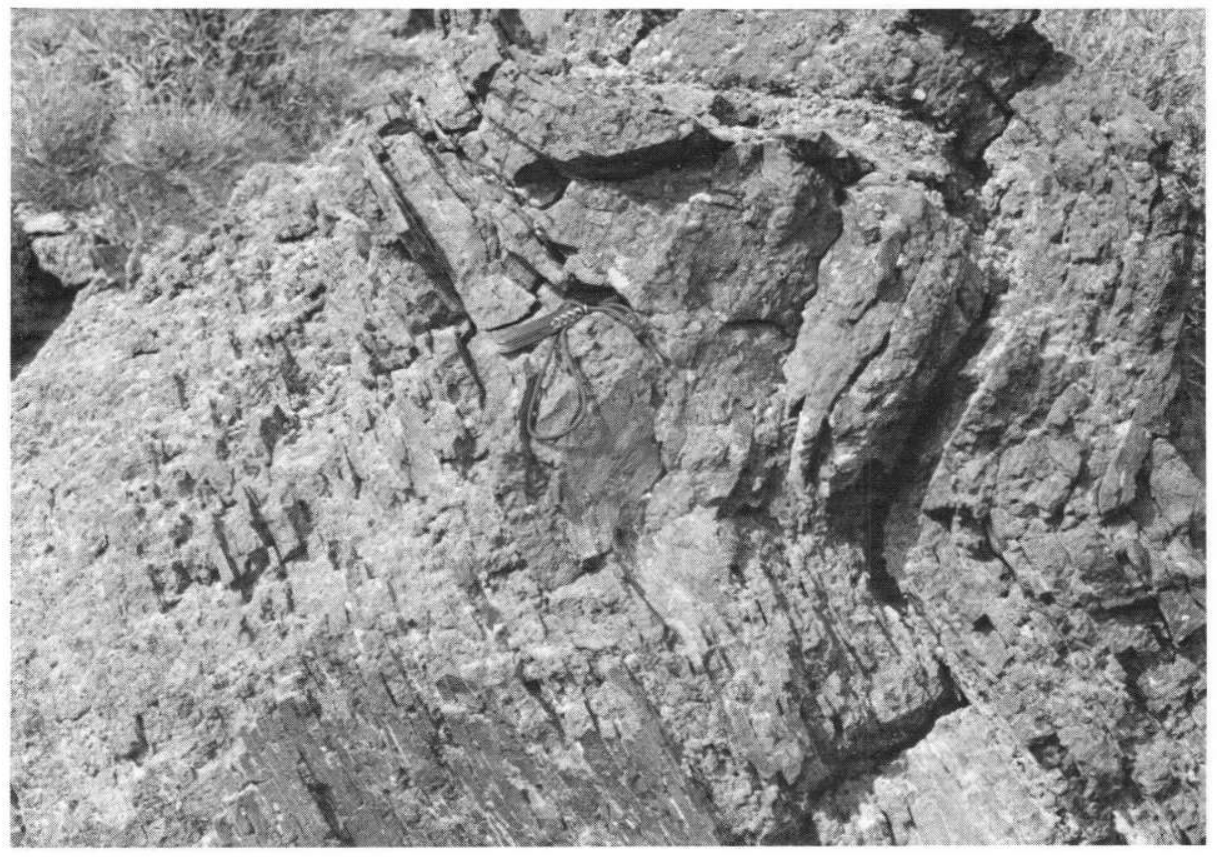

Figure 27. Outcrop of typical flow in Awakening rhyolite. Flow foliation imparts platy fabric. West Awakening Peak; knife is $9 \mathrm{~cm}$ long.

CA2156, which yielded an age of $13.6 \mathrm{Ma}$ (Conrad and others, 1993) shows it to be a low-silica rhyolite, not "andesite" as reported by Conrad and others. Analyses (table 2; recomputed on a volatile-free basis) average 70.3 wt. percent $\mathrm{SiO}_{2}$, lower than the average glassy Sleeper rhyolite, lower $\mathrm{Al}$ but higher $\mathrm{Na}$ and $\mathrm{K}$ than Sleeper rhyolite. Chemical analyses of the basal, sparsely porphyritic lavas in the Awakening rhyolite are less felsic (67-69 percent $\mathrm{SiO}_{2}$ ) than the higher flows with abundant phenocrysts (70-72 percent $\mathrm{SiO}_{2}$ ). In various petrologic calculations, analyses of samples of the Awakening rhyolite yield indices that overlap those of the Sleeper rhyolite.

Discussion. The Awakening rhyolite appears to be a fairly normal calc-alkaline rhyolite when compared with those elsewhere (for example, Carmichael and others, 1974). With about 70 percent $\mathrm{SiO}_{2}$ it is a low-silica variety, and with about 3 percent total iron $\left(\mathrm{Fe}_{2} \mathrm{O}_{3}\right)$, it is somewhat enriched in iron, perhaps a factor in the formation of the pyroxene. The pyroxene phenocrysts probably reflect higher crystallization temperatures than in more typical biotite-only rhyolites (Carmichael and others, 1974). Such higher temperatures might explain the prominent flow-banding in most of the unit.

The remarkable similarity of texture and composition to the Sleeper rhyolite probably is more fortuitous than petrologically or economically significant. The Awakening rhyolite must be at least 3 or 4 m.y. younger than the Sleeper rhyolite, and presumably was erupted from the same magma chamber. The similarity of chemistry and phenocrysts suggests that the eruptions tapped the same level of the magma chamber or that little differentiation occurred in the hiatus. (Compare Hildreth, 1979.) Post-mineral rhyolites may be a guide to Sleeper-type deposits, chiefly as indicators of favorable volcanic and tectonic environment. Fresh, post-ore lavas that overlie similar ore-bearing units are known elsewhere at Seven Troughs, Pershing County (G. Albino and J.T. Nash, unpub. data, 1993), and at Summitville, Colo. (Lipman, 1975).

Dikelike bodies of Awakening rhyolite, probably feeders for flow-domes, fill normal faults along the range front south of the Sleeper mine (pl. 1). These bodies are suggest that their major element composition overlaps that
of the Sleeper rhyolite (fig. 13). An analysis of sample 


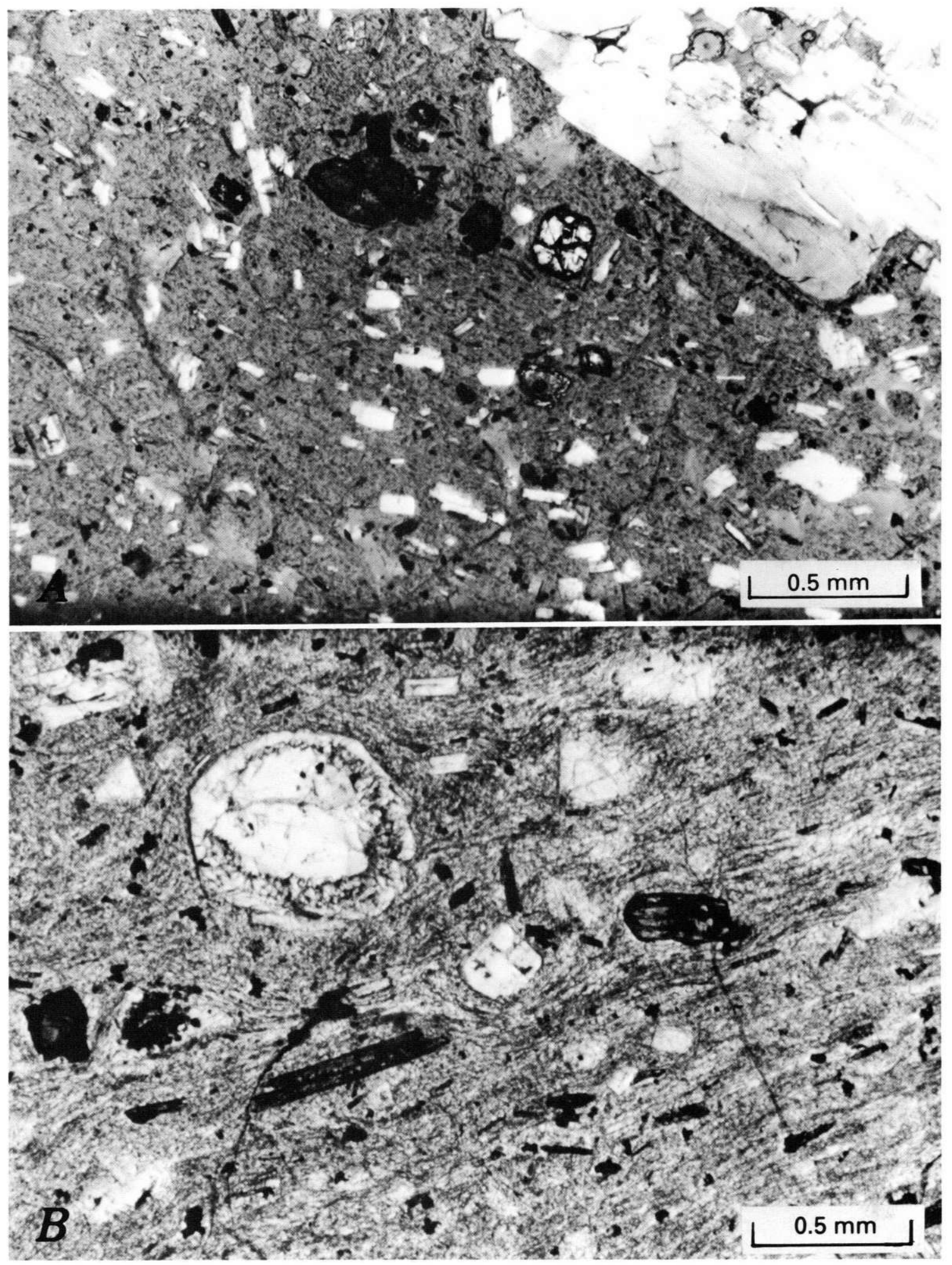

Figure 28. Photomicrographs of samples of Awakening rhyolite. A, Flow in Awakening rhyolite having characteristic rectangular micro-phenocrysts of plagioclase and pyroxenes in vitreous groundmass. Partly crossed polarizers. $B$, Drill cuttings of Awakening rhyolite $1 \mathrm{~km}$ south of Sleeper pit. Under hand lens this glassy porphyry looks like Sleeper rhyolite, but thin section shows distinctive FeMg-silicate minerals of Awakening rhyolite. Parallel light. 
pervasively bleached and appear to be silicified, but feldspars remain fresh. This mild alteration suggests that a geothermal system existed along the basin-and-range fault zone after 13.6 Ma but produced no gold-silver mineralization.

\section{SOME STRUCTURAL-STRATIGRAPHIC PROBLEMS}

Several unresolved structural or stratigraphic problems remain, and merit discussion to clarify relations shown on plate 1 and in figure 18. Tertiary rocks in the hills 2-4 km northeast of the mine (pl. 1) are a wellexposed sequence of two rhyolite ash-flow tuffs on andesite flows (fig. 25). These are the southernmost outcrops of the ash-flow tuff of Oregon Canyon $(16.1 \mathrm{Ma})$ and tuff of Long Ridge (15.6 Ma) (Rytuba and McKee, 1984; Conrad and others, 1993). These distinctive vitrophyres and welded tuffs have been identified in only one drill hole in Desert Valley about $2 \mathrm{~km}$ north of the pit (fig. 18). This identification was confirmed by petrographic study of cuttings; possibly this technique would permit identification of the rhyolite ash-flow tuffs in other drill holes. The rhyolite ash-flow tuffs have not been recognized in outcrop elsewhere in the Slumbering Hills. The distribution of the rhyolite ash-flow tuffs is influenced by Tertiary faulting and erosion. Preservation of the tuffs in Desert Valley appears to reflect cross faults as shown in figure 18; we presume that the tuffs were eroded at the Sleeper mine. Also, the Sleeper rhyolite has not been identified in this northeastern area to provide geologic evidence for its age relative to the rhyolite ash-flow tuffs.

East of the mine, several low hills are capped by quartz-feldspar porphyry flows that rest on intermediate composition flows. The felsic flows have phenocrysts, texture, and bulk composition that are virtually identical to features of the Sleeper rhyolite at the mine, but they are not as highly altered. A relatively fresh sample from one hill yielded a K/Ar age of $11.7 \mathrm{Ma}$ (Conrad and others, 1993), which is much younger than the rhyolite at the mine. Reexamination of that hill, and study of four new thin sections, revealed that the unit has a small amount of biotite and amphibole ( $<4$ percent total), which are similar to the Awakening rhyolite. The major element composition of a glassy sample is within the range of both the Sleeper rhyolite and the Awakening rhyolite. Unlike most of the Awakening rhyolite, this body of rhyolite is pervasively argillized (which enhances its megascopic similarity to the Sleeper rhyolite). A bed of probable rhyolitic crystal tuff underlies the problematic rhyolite flow; the crystal tuff(?) closely resembles one discontinuously present at the base of the Sleeper rhyolite below the Sleeper pit. The biotite rhyolite flow may be equivalent to biotite-bearing rhyolite intersected in drill core below the pit, but there are textural differences. Ambiguities remain, but the alteration suggests that the rhyolite is more akin to the Sleeper rhyolite than to the Awakening rhyolite, and it probably is a separate flowdome. A similar age of $11.8 \mathrm{Ma}$ was obtained on a sample of Sleeper rhyolite from the hill $1 \mathrm{~km}$ southeast of the mine. Numerous thin sections from that area show textures and compositions that are identical to those from the nearby Wood sub-pit. The $11 \mathrm{Ma}$ ages on these rhyolite flows are considered to be reset, probably related to the pervasive silicification along basin-and-range faults.

Southeast of the mine, prominent ridges with cliffy outcrops are underlain by little-altered Awakening rhyolite lavas from several flow-domes. The 13.6 Ma rhyolite flows, which must have once covered the Jumbo mine area, indicate that a considerable thickness of Mesozoic and Tertiary rocks (perhaps $1,000 \mathrm{~m}$ ) was eroded in less than $4 \mathrm{~m}$.y. to expose the Jumbo veins. Small outcrops of Awakening rhyolite between the informally named ZZ-top and the Sleeper mine, and drill intercepts in Desert Valley, suggest that the Awakening rhyolite probably extended over the Sleeper deposit. An altered quartz latite (rhyolite?) intrusion with steeply dipping flow-banding characteristic of a dome is lithologically and chemically similar to the Sleeper rhyolite. The alteration and composition of the quartz latite suggest that it is related to the Sleeper rhyolite. Flows from this shallow intrusion are not evident but possibly were eroded. South of ZZ-top, across the deep canyon, is a body of weakly silicified, biotite-bearing rhyolite having steeply dipping flow-banding. Petrographic study provides conclusive evidence that this weakly altered rhyolite is Sleeper type. The body is probably a dome, but might be highly rotated flows. Relations on this ridge indicate large displacement on north-striking normal faults and probably large amounts of local erosion prior to emplacement of Awakening rhyolite lavas. Andesitic and basaltic flows in this southeastem area, and especially on ZZ-top, generally resemble those in the mine and northeast areas, but are less altered. Outcrops north of ZZ-top are sparse, but those of intermediate-composition flows appear to correlate with those at the mine. South of ZZ-top the intermediate lavas are much thinner than to the north. An earlier interpretation (Nash and others, 1991, fig. 2) postulated that the andesitebasalt flows on ZZ-top were younger than those at the mine.

As for the mine area, the Tertiary section, described in detail earlier, does not include the rhyolite ash-flow tuff of Oregon Canyon and tuff of Long Ridge, but these units have been identified in two drill holes north and south of the mine. The tuffs probably were deposited above the Sleeper rhyolite, and then were eroded. The Awakening rhyolite disconformably overlies the Sleeper rhyolite $1 \mathrm{~km}$ south of the pit and may have extended north to cover ore, but was eroded later. The original extent of these Miocene rhyolites may have been significant for ore formation and preservation. The rhyolite tuffs are the only known 
post-Sleeper rhyolite that could have been present during ore deposition. Cover by the Awakening rhyolite would have helped preserve the Sleeper orebody from Miocene erosion. A drill hole $1 \mathrm{~km}$ south of the pit cut about $230 \mathrm{~m}$ of Awakening rhyolite, although other holes south of the mine record lesser amounts of preserved Awakening rhyolite. Incomplete information south and east of the mine indicates significant differences in unit thicknesses, attributed to large amounts of Miocene-Holocene erosion, in various structural blocks.

\section{GEOLOGY OF THE SLEEPER MINE \\ HOST ROCKS}

Ore in the Sleeper deposit is hosted by Sleeper rhyolite, lapilli tuff, and intermediate lavas (pl. 2). Oregrade intercepts are known in Mesozoic metasedimentary rocks, and the volcaniclastic sedimentary rocks that occur below the deposit (fig. 29) contain no ore. The orebody, as currently defined by the expanded pit, is predominantly in

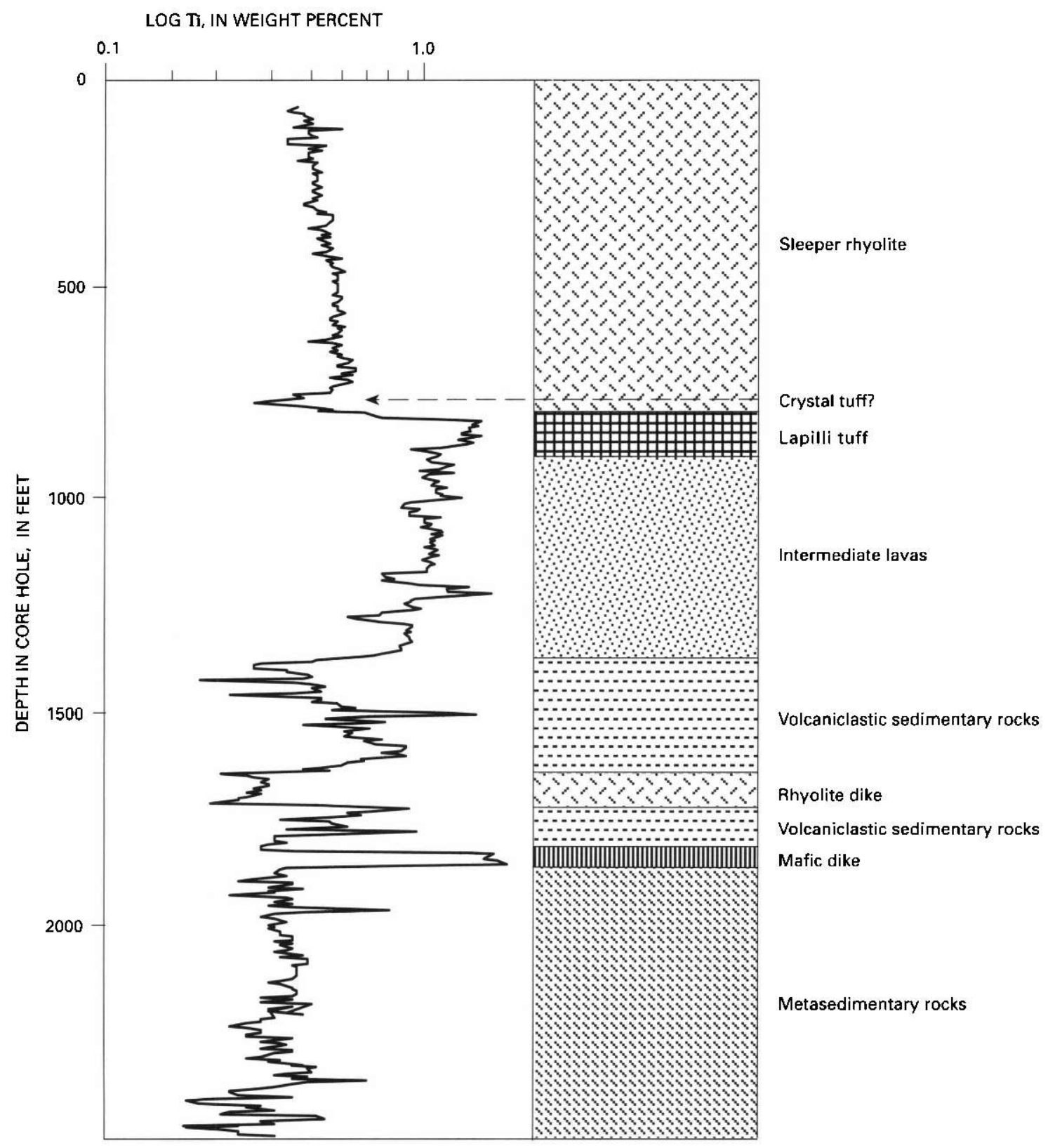

Figure 29. Typical Tertiary section in Sleeper mine. Section is based chiefly on deep vertical core hole MC-08, collared on the west side of the Sleeper sub-pit. Distribution of titanium is useful for determination of original rock type in zones of alteration. 


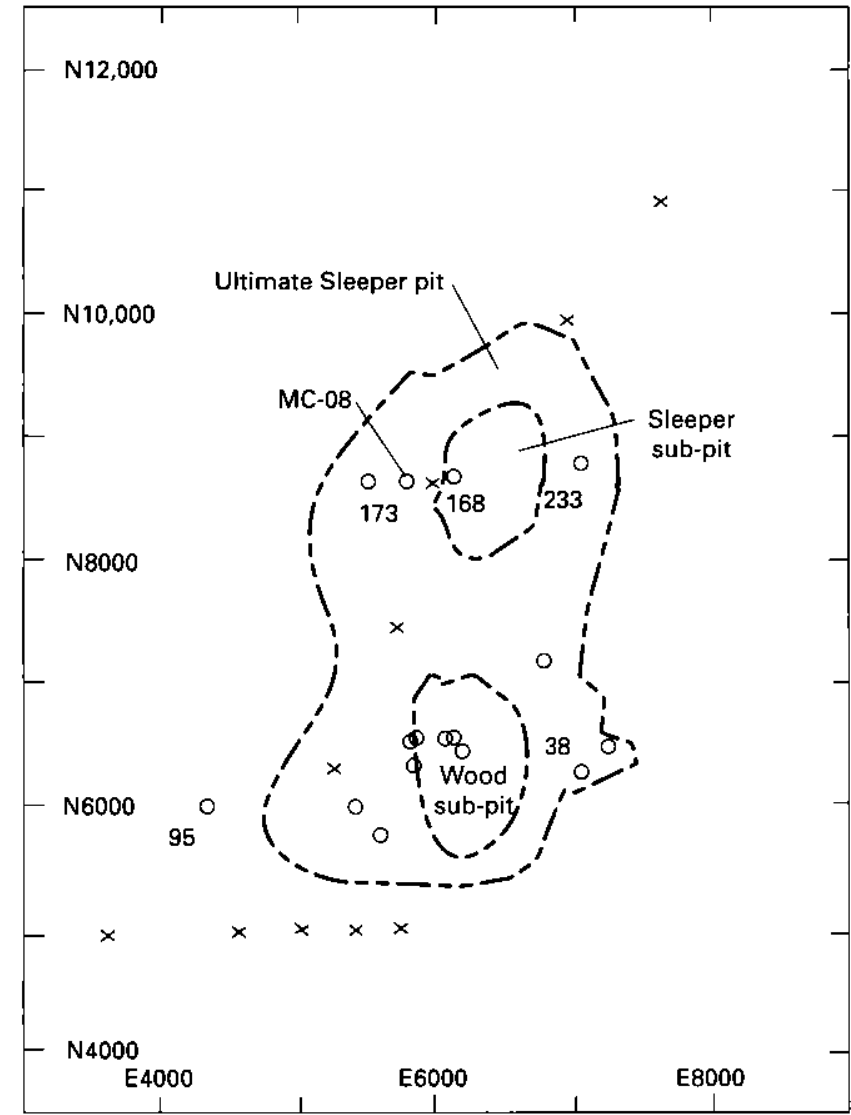

A

Sleeper rhyolite, and more than 90 percent of ore values are in rhyolite. (Note that the expanded or "ultimate" Sleeper pit encompasses the original Sleeper pit (now sub-pit) and the Wood pit (sub-pit) (fig. 30).) Ore-grade intercepts and extensions below the planned pit, in intermediate lavas and metasedimentary rocks, are being evaluated as targets for underground mining. Basal channels of Pliocene gravel, unconformably overlying Sleeper rhyolite, contain substantial amounts of alluvial gold.

The thickness of Tertiary volcanic units is quite uniform in the mine area (figs. 16, 17,30), despite faulting and erosion. The lapilli tuff is least consistent in thickness (fig. $30 \mathrm{C}$ ), consistent with its postulated formation as a tuff cone that was easily eroded.

The Sleeper rhyolite exposed in the pit, and intercepted in numerous drill holes, is intensely to weakly altered, but its initial texture and composition were remarkably consistent. Plagioclase, sanidine, and quartz phenocryst abundances and textures, or their pre-alteration sites, are so consistent that one initially has the impression that the body could be a porphyritic stock. Fabric is generally massive, and compositional layering is not evident. At a few localities flowbanding is preserved and dips about $30^{\circ} \mathrm{E}$. Most contacts in

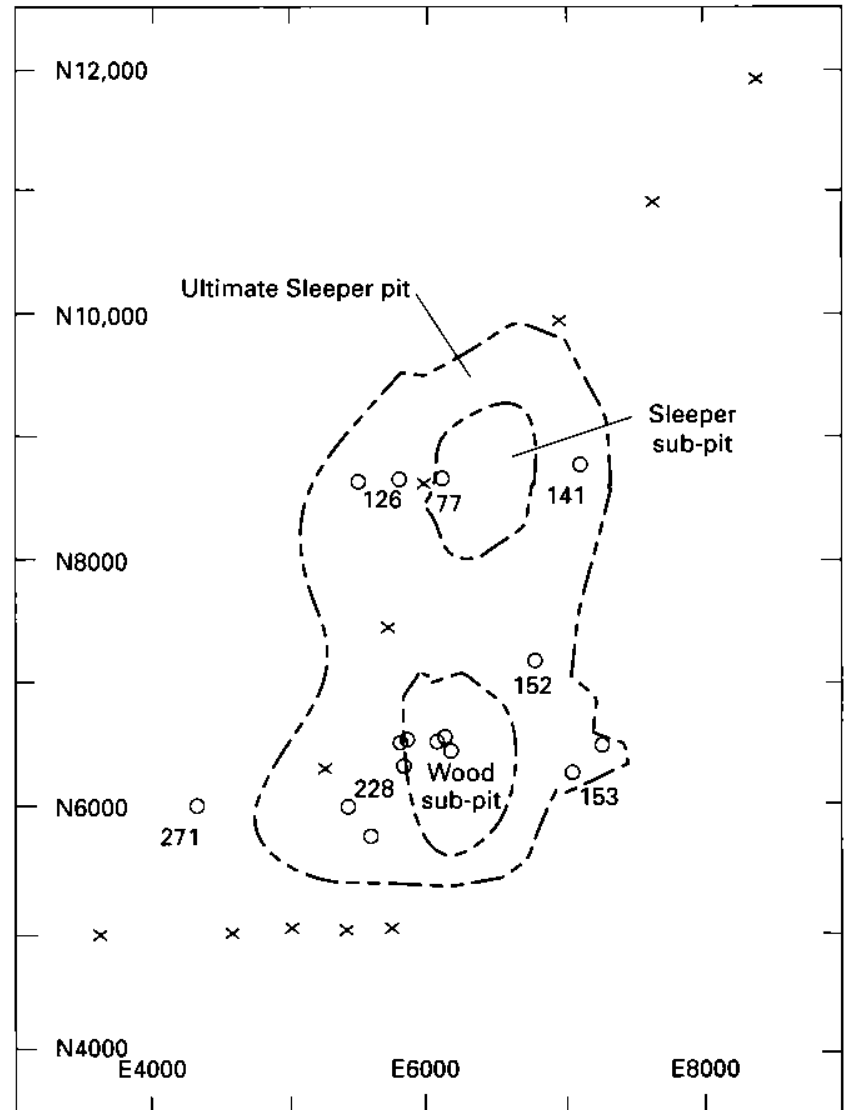

B

the pit are faults (pl. 2), but some drill hole intercepts suggest deposition of Sleeper rhyolite on lapilli tuff and intermediate lavas, a concept which is supported by geometry in cross sections (pl. 1, figs. 16, 17). Intrusive contacts are seen for a dike of Sleeper rhyolite in the Sleeper sub-pit (pl. 2), and in dikes and sills of Sleeper rhyolite cut in drill core below the pit. Most of the bedrock east, south, and west of the pit is Sleeper rhyolite (figs. 16, 17, 18).

Massive to well-layered rocks of intermediate composition are exposed in the east wall of the Sleeper pit. These were flows, flow-breccias, air-fall tuffs, and lapilli tuffs from nearby vents. These rocks are assigned to the lapilli tuff and intermediate lava units. Dikes of Sleeper rhyolite intrude the flows and tuffs, but the main rhyolite body is in fault contact with these rocks in most places. Beds and compositional layering strike north-south to $\mathrm{N} .40^{\circ} \mathrm{W}$. and dip about $30^{\circ}$ to $50^{\circ}$ E. in the few localities where dips can be determined. The general map pattern, in which exposures of these rocks are repeated by normal faults (pl. 2), suggests that the bedded volcanic rocks have relatively low dip. The volcaniclastic sedimentary rock unit, with interbedded conglomerate, underlies the intermediate lavas and is not exposed in the mine. 


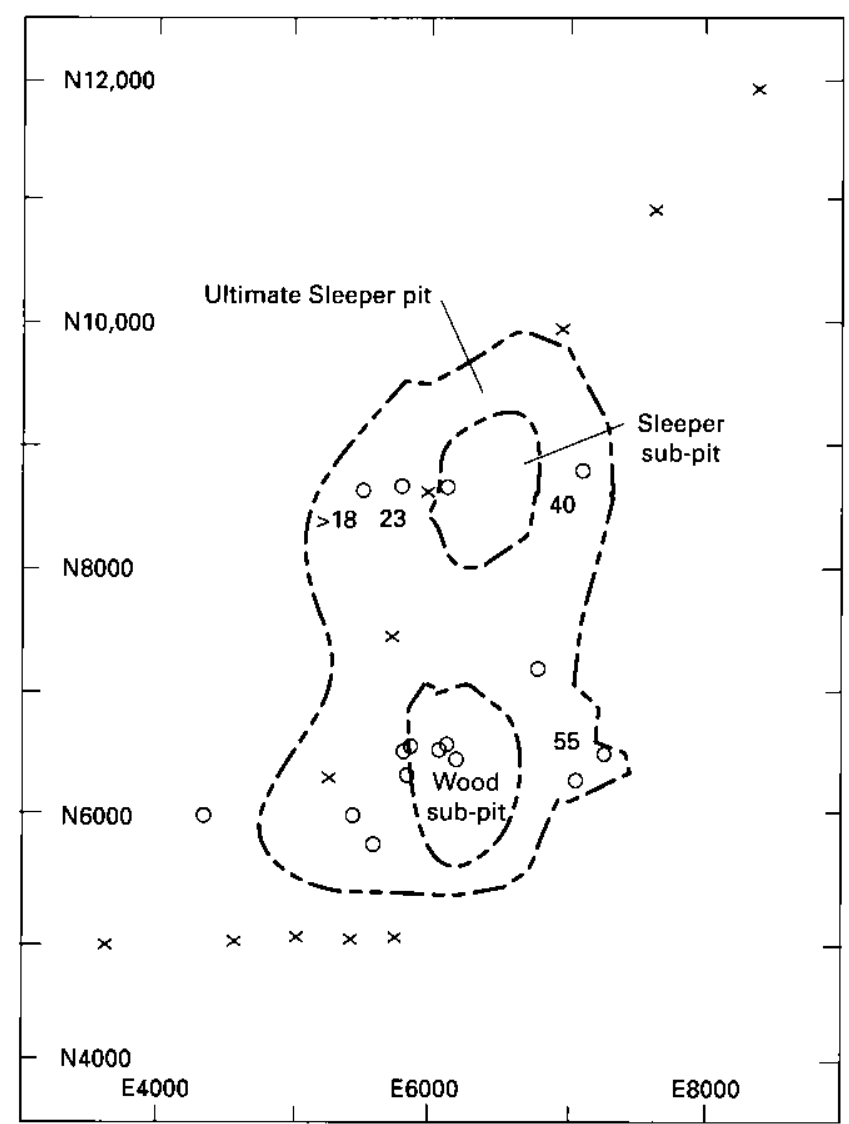

C

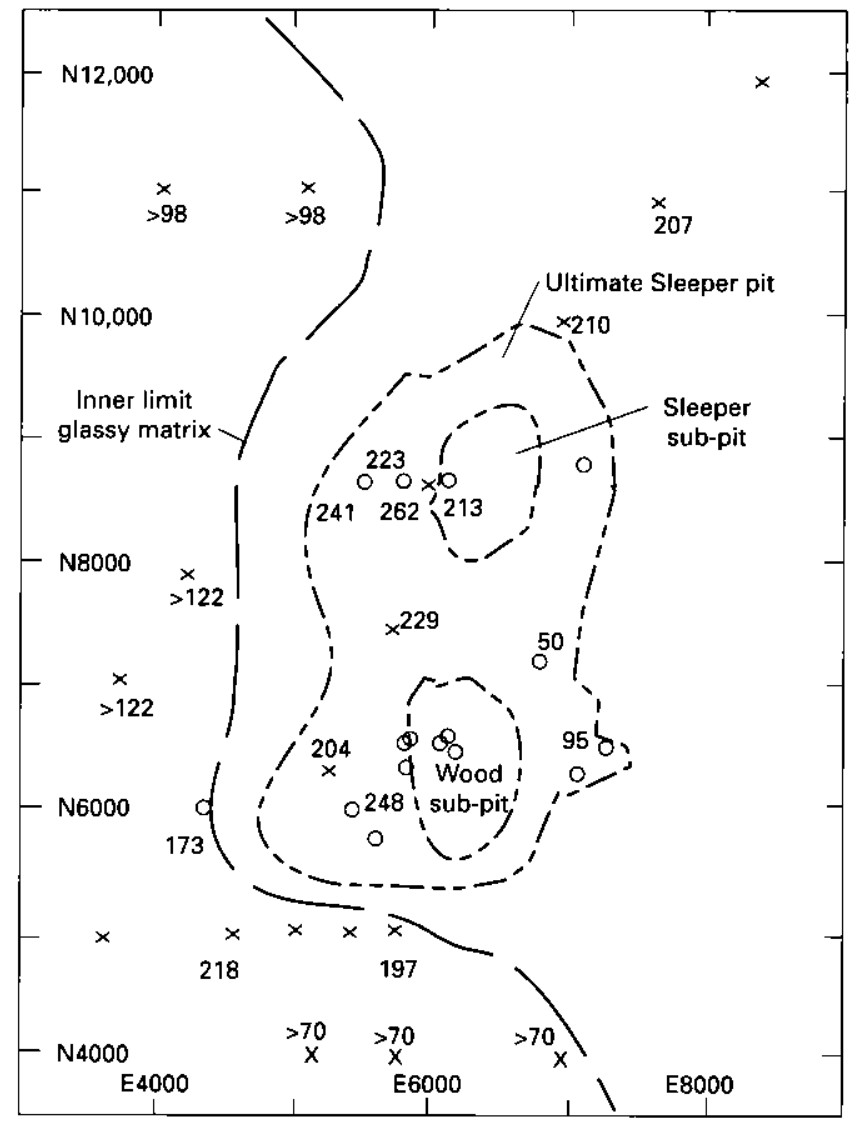

D

Figure 30 (above and facing page). Thicknesses of Tertiary units in the Sleeper mine area determined chiefly from deep core drill holes. Open circle, core hole; $\mathrm{X}$, rotary drill hole; numeral, unit thickness, in meters. $A$, volcaniclastic sedimentary rock unit; $B$, intermediate lavas; $C$, lapilli tuff; $D$, Sleeper rhyolite. MC $\_08$, vertical core hole, basis for section of figure 29 .

\section{STRUCTURE}

Faults and fractures of several ages and orientations are the dominant structural features of the mine (pl. 2, figs. 16, 31 ). Intensity of fracturing is highly variable, from rare broadly spaced fractures (as in the southeastern Wood subpit) to intensely shattered rubble along basin-and-range fault zones. Most of the fracturing is younger than ore formation and is uncemented except for thin films of supergene clay, opal, or alunite. All stages of ore are clearly fracture controlled, but evidence for pre-mineralization displacement along these fractures is lacking. Also, ore-bearing structures tend to be obscured by the more obvious post-ore structures, especially the range-front faults that have broad zones of unhealed fracturing. All faults with measurable offset, and the majority of fractures, are post-ore. Determination of relative ages of fault movement is generally ambiguous because the faults are zones of breakage, not planar surfaces, and they have had several stages of movement.

Faults with approximate north strike are dominant in many places, as for example where intermediate lavas are faulted against Sleeper rhyolite in the deeper parts of the Sleeper and Wood sub-pits, but these same faults have deceptively simple expression where both walls of the fault are the same unit. Faults with northwest or northeast strikes were relatively inconspicuous in the upper parts of the mine during early years of mining, but the deeper and wider expanded pit displays significant offset along these faults. A series of northwest-striking normal faults are the southern termination of lapilli tuff and intermediate lavas in the middle part of the pit. Structure of the mid-pit area is an extremely complex mosaic of faults with diverse attitudes. Relations shown on plate 2 are generalized from observations at several depths of mining and are only a partial description of the nature of cross-faulting. Exposures in the open pit mine are not nearly as complete as in an underground mine (and we were not able to map temporary exposures on a daily basis), but they do provide a relatively good view of basin-and-range structures that are rarely seen in natural outcrops.

The oldest faults in Tertiary rocks are normal faults that strike about N. $10^{\circ} \mathrm{E}$. and dip $50^{\circ}$ to $70^{\circ} \mathrm{W}$. A good example 
c WEST

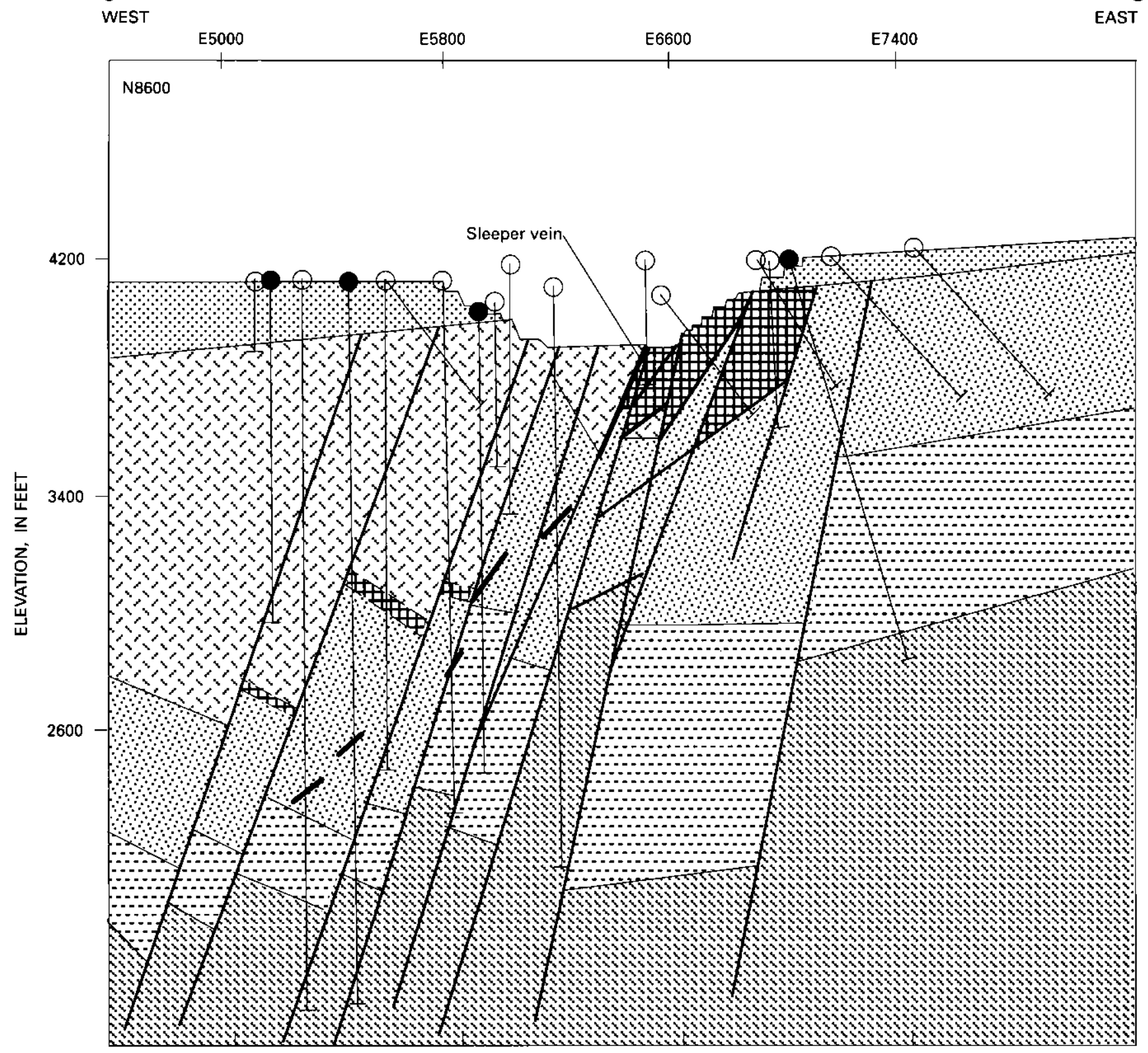

EXPLANATION

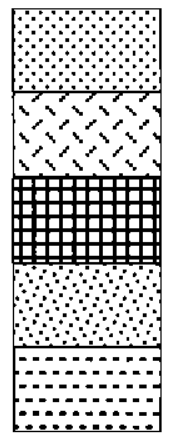

Older alluvium (Quatemary-Pliocene)

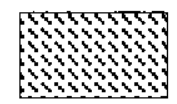

Metasedimentary rocks (Mesozoic)

Sleeper rhyolite (Miocene)

Contact-Approximately located

Lapilli tuff (Miocene)

Intermediate lavas (Miocene)

Volcaniclastic sedimentary rocks (Miocene?)

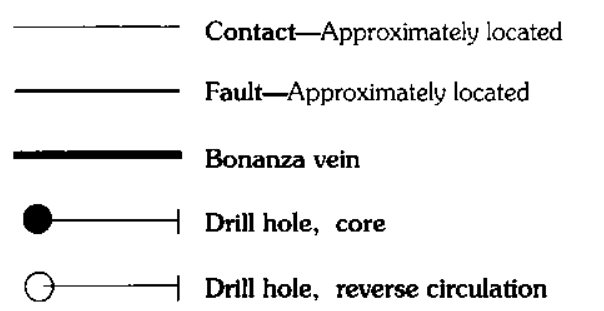

Figure 31. Generalized geologic cross section $C-C^{\prime}$ through northem part of Sleeper deposit ( $8600 \mathrm{~N}$ ). Distribution of rhyolite and metasedimentary rocks is reliably determined by drilling, but lapilli tuff and volcaniclastic sedimentary rocks are poorly known in reverse circulation drilling and are generalized here. Faults shown are interpretations and many smaller faults are not shown; exposures in pits confirm horst-graben character of displacement on basin-and-range faults. Rotation of structural blocks is schematic, but consistent with dips of primary structures in core and with dips in the foothills. Vein intercepts shown are not necessarily the Sleeper vein. Line of section shown on plate 1. 
is the fault that places intermediate lavas against Sleeper rhyolite on the central-east wall of the ultimate pit (pl. 2); this fault is considered to be early because the fault and rocks on both sides are intensely silicified and pyritized. Some of the early faults (or fractures with small displacement) are filled by high-grade veins that consistently strike $\mathrm{N} .10^{\circ} \mathrm{E}$. and dip $60^{\circ}-65^{\circ} \mathrm{NW}$. (fig. 32 ), which is nearly the same orientation as the younger basin-and-range faults. The vein-filled structures show no demonstrable displacement, perhaps in part because they occur almost exclusively within one rock type (Sleeper rhyolite). Vein widths of $0.2-4 \mathrm{~m}$ and delicate banding indicate that the structures were open for a significant period of time, which is consistent with extensional tectonics of the Basin and Range province in the middle Miocene.

The southern termination of the East Wood vein was well exposed in the pit in 1989-90 when the mining level was totally in Sleeper rhyolite. The banded quartz vein narrowed progressively from over $1 \mathrm{~m}$ wide to a few centimeters, across a strike distance of about $50 \mathrm{~m}$ to the south. The alteration halo of intense silicification narrowed as well, until finally there was less than a foot (about $0.3 \mathrm{~m}$ ) of silicified rock in a fracture zone, and ultimately the fracture zone was not evident within the Sleeper rhyolite. Most likely the fault opening died out, which caused diminished alteration and gold-silver deposition in the vein. Stockwork-type mineralization continued a short distance to the south and grade decreased to less than $0.01 \mathrm{oz} / \mathrm{ton}$ in crumbly, argillized rhyolite.

Two major basin-and-range fault zones in the Wood and Sleeper sub-pits (pl. 2) are in the footwall of high-grade veins, generally staying just east of the intensely silicified Sleeper rhyolite along the vein, but strands of the range-front fault do cut and fragment the north ends of these veins. Drill evaluation of the fragmented portions of the veins is difficult,

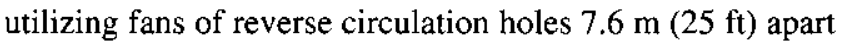
along strike as well as assays of blast-hole cuttings. Grade control is best done by careful observation during mining to ensure that the veins are selectively mined and processed through the mill because coarse gold grains in veins are not effectively leached on the heap leach pads.

Displacement on numerous basin-and-range faults is complex in three dimensions (pl. 2, fig. 31). These fault zones are essentially filled by chaotic rubble. Only the major fault surfaces or lithologic breaks are shown. Strikes are north-south to N. $20^{\circ} \mathrm{E}$., and dips are generally $60^{\circ}-80^{\circ} \mathrm{W}$.; a few splays have dips of $40^{\circ}-60^{\circ} \mathrm{E}$. Offsets are best estimated from drilling information on deeper, unexposed units (fig. 31). In 1990, deeper and wider mining exposed faultbound blocks (pl. 2) that demonstrated upward displacement of some blocks 10-100 $\mathrm{m}$ wide, and also slices a few meters wide. Most structural blocks are so highly fractured, sheared, and altered that lithologic contacts are difficult to determine. Cross-faults with strikes of about N. $30^{\circ}$ to N. $60^{\circ} \mathrm{W}$. and E. appear to terminate the blocks, but relations are obscure. Soft tuffaceous lithologies are poorly represented in reverse crculation drilling, thus imperfectly known at depth (fig. 31).
We suspect repeated stages of movement on these major faults, but have proof at only a few localities. Basalt dikes (Pliocene?) are cut by the major basin-and-range fault in the Sleeper sub-pit (not exposed at the level of pl. 2). A normal fault exposed at the north end of the pit in 1994 displaces Sleeper rhyolite (down $18 \mathrm{~m}$ on west side), and contributed to the formation of a lens of Tertiary conglomerate, described earlier. Older alluvium in the mine is displaced as much as a meter by normal faults.

Breccias and stockwork fracture zones cemented by silica-pyrite-marcasite and containing variable amounts of $\mathrm{Ag}$ and $\mathrm{Au}$ occur adjacent to the veins and in broad areas of the hanging walls. The stockworks and breccias probably are related because the two structures are gradational; differences are chiefly the amounts of matrix or cement, which reflect the amount of dilation. Breccias are clast-supported rocks with about $15-30$ percent matrix comprised of fine rock particles and hydrothermal cement. Stockworks are fractured rocks cut by numerous thin veinlets $(<1 \mathrm{~cm})$ of random orientation. Some mineralized breccias may be related to faults, but most appear to be erratic local structures having no displacement. Breccia zones generally are $0.5-5 \mathrm{~m}$ wide, but stockwork zones extend for more than $100 \mathrm{~m}$, especially in the hanging walls (west) of the veins. Breccias invariably contain only fragments of adjacent rocks. Banded quartz vein fragments in some breccias indicate that those breccias are younger than the veins, whereas other (older) breccias are cut by banded gold-quartz veins.

Numerous late, unhealed faults and fractures have steep dips and diverse strikes, most commonly N. $30^{\circ}-45^{\circ}$ E., N. $30^{\circ}-45^{\circ} \mathrm{W}$., and due north to N. $10^{\circ} \mathrm{E}$. In places where fracture zones intersect, wall rocks and ore are broken into centimeter-size fragments. Offset along the late cross-faults generally cannot be determined except where high-grade veins are displaced. A few offsets of as much as $6 \mathrm{~m}$ have been noted (fig. 32); sense of displacement could be lateral, vertical, or a combination of both. The age or ages of these fractures and faults are not well known; some appear to be related to north-striking basin-and-range faults, but others may be younger. The upper parts of some of the north- and northwest-striking fracture zones were the sites of nearsurface acid leaching and subsequent infilling by opal and white to brown alunite-jarosite. This late-stage alunite has been dated at $5.4 \mathrm{Ma}$ by $\mathrm{K} / \mathrm{Ar}$ methods (Conrad and others, 1993).

Rocks and veins in the mine were tilted by basin-andrange faults, as they are in the foothills to the east. Some drill cores of weakly altered rocks show compositional layering and flow-banding with dips most typically in the range of $20^{\circ}-30^{\circ}$; strike cannot be determined from unoriented core. Most logically the dips would be to the east, as in foothills outcrops. The complex and locally chaotic faulting in the fault zones suggests that blocks have different amounts of rotation. If host rocks were indeed rotated about $20^{\circ}-30^{\circ}$, it 


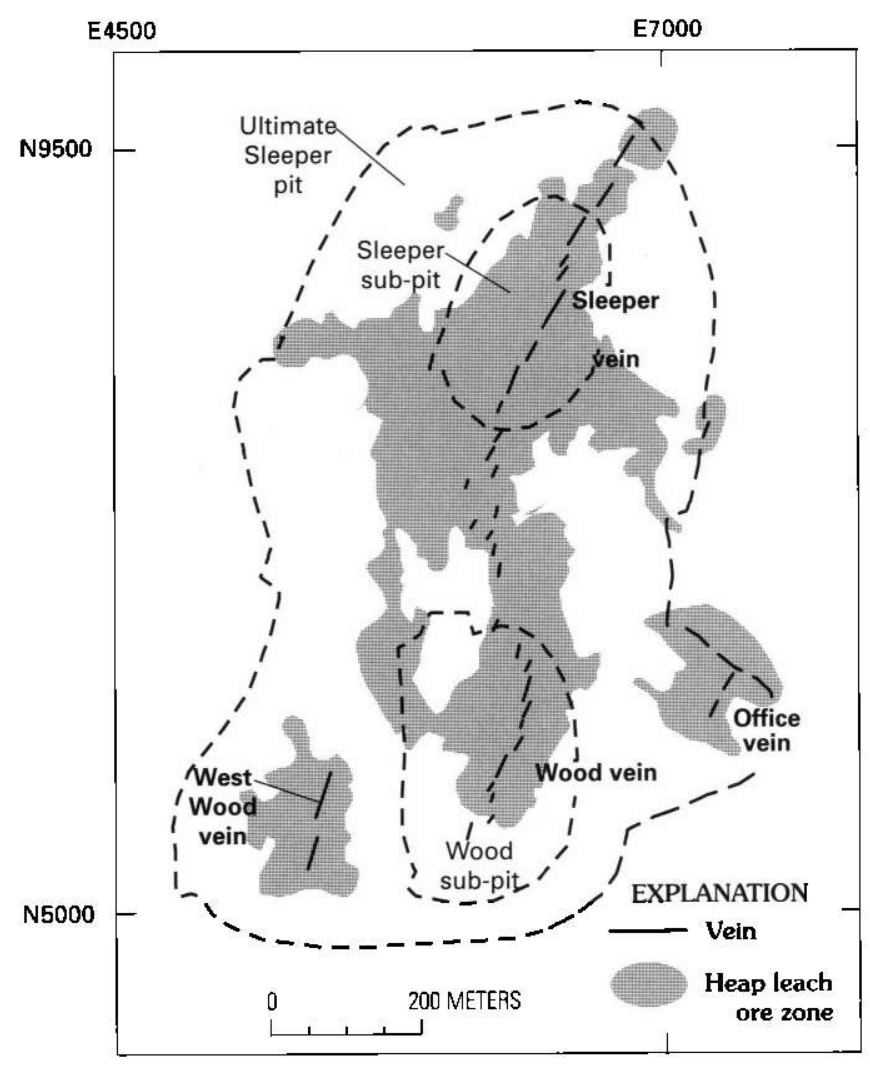

Figure 32. Generalized distribution of ore in Sleeper mine, showing vein and heap leach types. The zone of heap leach ore, grading $>0.01 \mathrm{oz} /$ ton gold, is for the $4000 \mathrm{ft}$ bench; extent of ore beyond the planned pit limit is not complete or accurate.

is possible that the bonanza veins originally filled nearvertical structures.

A key feature of the Sleeper deposit is the superposition of multiple, structurally controlled stages of mineralization. This range-front zone also is characterized by multiple intrusive and eruptive events, as well as repeated stages of postore faulting. We infer the presence of an ancestral fracture zone that established the location of the volcanic vents, prevein silicification, and veins. Once established, the zone of early silicification became the locus for repeated brittle fracturing for veins, stockwork veinlets, and breccias. Silicified Sleeper rhyolite was most favored for the brittle deformation, but layered dacitic tuffs and flows that were previously silicified also were fractured and mineralized.

\section{ORE DEPOSITS}

Four geologic types of gold-silver ore are mined at Sleeper: high-grade veins, medium-grade breccias, lowgrade stockworks, and alluvial deposits in Pliocene gravel. For purposes of mining two major types are distinguished, selectively mined high-grade vein with some adjacent breccia having grades in excess of about $0.1 \mathrm{oz} /$ ton, which is processed through the mill, and bulk-mined breccia and stockworks having grades as low as $0.01 \mathrm{oz} / \mathrm{ton}$, which are processed through the crusher and stacked on leach pads. Alluvial gold zones contain clasts of vein bearing coarse gold and must be processed through the mill. The general distribution of ore types is shown in figure 32 . The high-grade bonanza veins are highly localized by fractures (or faults with small displacement), whereas the low-grade ore is broadly distributed in small structures.

The high-grade veins (fig. 33A-D) are banded quartzadularia-gold/electrum veins with minor carbonate, barite, and late stibnite (Nash and others, 1991; Saunders, 1994). Assays are as high as $195 \mathrm{oz} / \mathrm{ton}$ gold over a $6.1-\mathrm{m}(20-\mathrm{ft})$ vertical blasthole or $162 \mathrm{oz} /$ ton gold for a 1.5 - $\mathrm{m}$ interval (true thickness) of reverse circulation cuttings; Ag:Au ratios are 1 or less. The veins contribute more than 60 percent of reserves.

Breccias (fig. $33 E-G$ ) cemented by silica, pyrite, and minor adularia typically contain 0.1 to $1 \mathrm{oz} /$ ton gold; $\mathrm{Ag}: \mathrm{Au}$ ratios are in the range of $3-6$. Breccia ore generally is within $5 \mathrm{~m}$ of high-grade veins but also occurs as discrete zones several meters wide in both footwall and hanging-wall rocks. Approximately half the breccia ore, chiefly that near veins, is processed through the mill.

Stockwork ore containing numerous $1-10 \mathrm{~mm}$-wide quartz-pyrite veinlets (fig. $34 B$ ) generally carries less than $0.1 \mathrm{oz} /$ ton gold; Ag:Au ratios are about 10 . The pit was redesigned and expanded in 1990 after the first leach pads proved very successful on the lower grade, bulk-mined ore. The expanded pit and leach pads will produce approximately a million ounces of gold, chiefly from these low-grade stockwork ores (Nash and others, 1991). The broad distribution of stockwork ores (fig. 32), and minimal metallurgical complications on the leach pads, make these ores amenable to bulk mining and routine processing for heap leaching.

Figure 33 (facing page). Photographs of veins, breccias, and stockworks. A, Part of Wood vein, about $70 \mathrm{~cm}$ wide, with three intervals of banded vein (pen for scale). $B$, Banded vein showing fine and disrupted (d) bands (sample is $18 \mathrm{~cm}$ wide). $C$, High-grade vein sample showing fine and disrupted bands and layers rich in electrum (e). $D$, Banded quartz vein showing later stage of dark-colored quartz and crosscutting stockwork veinlet. $E$, Hydrothermal breccia with fragments of vein and dark silica-pyrite-marcasite matrix (sample is $17 \mathrm{~cm}$ wide). $F$, Hydrothermal breccia having angular fragments of silicified rhyolite in matrix of fine rock fragments and silica (transmitted light). $G$, Hydrothermal breccia with angular and subrounded fragments cemented by silica-pyrite-marcasite (transmitted light). $H$, Extremely fine grained pyrite in matrix of a hydrothernal breccia; the texture of the fine pyrite crystals, including framboids, probably reflects extreme supersaturation (scanning electron microscope image from a polished section). 

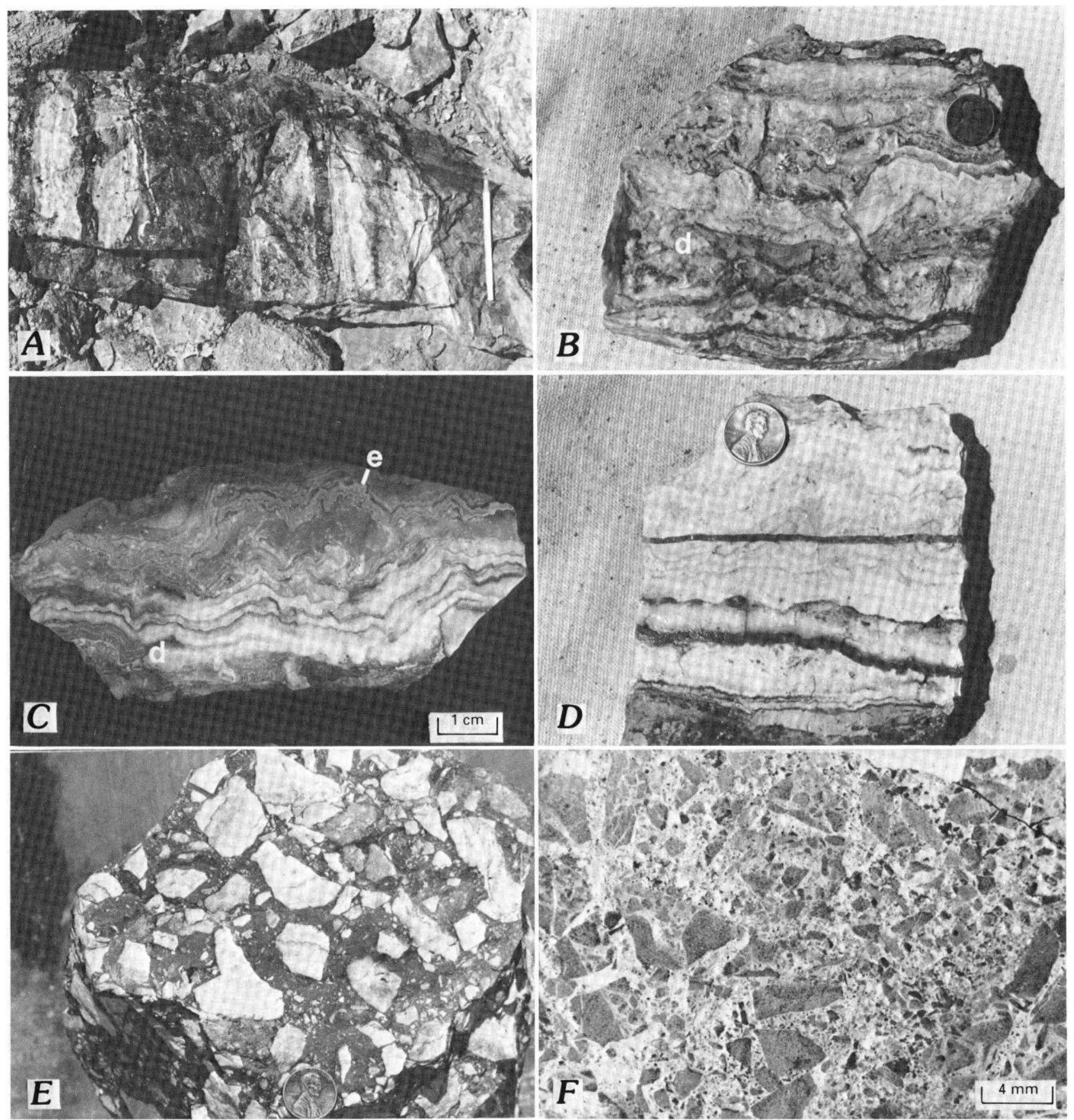

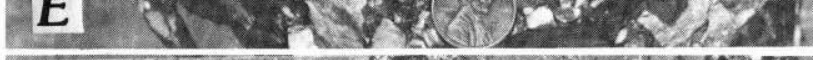

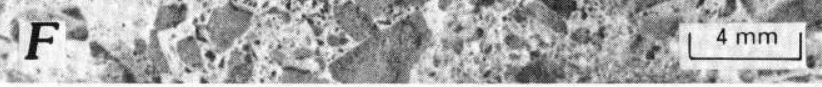
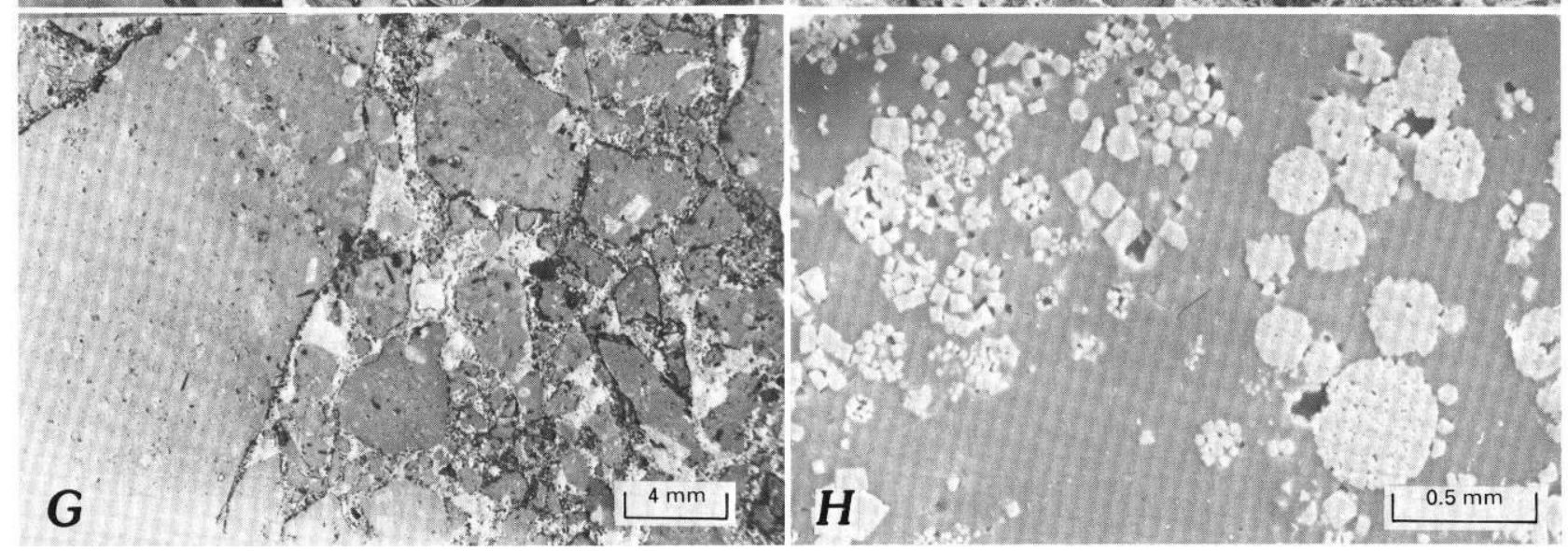
High-grade (Bonanza) Veins. Banded high-grade veins that range from a few centimeters to $4 \mathrm{~m}$ thick (fig. $33 A-D$ ) have been mined in four vein systems: the Sleeper, East Wood, West Wood, and Office (fig. 32). Numerous other narrower or shorter veins have been found in drilling and mining, including several below the currently planned ultimate pit which are in metasedimentary rocks. Some highgrade veins lie totally within andesite flows, or in andesite as continuations from rhyolite. The largest and richest veins occur in silicified Sleeper rhyolite. Although post-ore faults offset the veins, detailed drilling and pit mapping show that the trends are quite consistent along strike for distances of more than $200 \mathrm{~m}$ (fig. 32), and downdip for more than $300 \mathrm{~m}$ (fig. 31). Veins occur in a zone more than $300 \mathrm{~m}$ wide and more than $1,200 \mathrm{~m}$ long. The limited amount of deep drilling $(>300 \mathrm{~m})$ and complex structure do not permit assessment of reserves below the 3560 bench $(3,560 \mathrm{ft}(1,085 \mathrm{~m})$ elevation, pit depth about $600 \mathrm{ft}(183 \mathrm{~m}))$, but there are significant intercepts more than $300 \mathrm{~m}$ below the planned pit (Nash and others, 1991). These deep intercepts cannot be proven to be the Sleeper vein as such because of the many known and suspected post-ore faults; they could also represent a set of enechelon veins related to the bonanza veins at higher levels. A few very deep holes that penetrated metasedimentary rocks intercepted quartz-adularia-gold veins.

Breccia and Stockwork Ores. Siliceous breccias and stockworks constitute an important part of the Sleeper orebody. These ore types are notably richer in pyrite-marcasite and have higher Ag:Au ratios than the high-grade veins. The breccias are mostly clast supported and have approximately 15-30 percent matrix comprised of very fine grained silica and pyrite-marcasite (fig. $33 E-G$ ). Nearly all clasts are monolithologic and the same lithology as nearby unbrecciated wall rocks. Size of angular clasts ranges from about 30 $\mathrm{cm}$ to fine "rock flour" $(<0.1 \mathrm{~mm}$ ) in the matrix (fig. $33 F, G$ ). The breccia zones are generally $1-3 \mathrm{~m}$ wide and grade laterally into less brecciated wall rock cut by stockwork veins that fill dilatant structures. At some localities we have been able to determine multiple stages of brecciation as evidenced by crosscutting relations or presence of breccia clasts in breccia. No displacement is associated with the breccia zones. These features are characteristic of hydrothermal rather than tectonic breccias (Nelson and Giles, 1985; Wood, 1988).

Large volumes of silicified rock are cut by quartzsulfide stockwork veinlets containing small amounts of silver and gold that contribute about 20 percent of the total reserves. The veinlets generally are a few millimeters wide, spaced several centimeters apart, and are most widespread in silicified Sleeper rhyolite. Most stockwork veinlets are associated with pervasive early silicification, although later, crosscutting veinlets exist. The rarity of stockworks (and significant amounts of silver and gold) in argillized rocks appears to chiefly reflect physical conditions (lack of brittle character).
A characteristic feature of the quartz-sulfide veinlets and breccia fill is the extremely fine grained pyrite and marcasite (fig. $33 H$ ). Pyrite, the dominant form of $\mathrm{FeS}_{2}$, occurs as isolated euhedra (cubes, pyritohedra, dodecahedra) less than $5 \mu \mathrm{m}$ in diameter, clusters of attached or touching euhedra (individual crystals $<2 \mu \mathrm{m}$ diameter), clusters of euhedra in spherical aggregates termed "framboidal" (French for raspberry) elsewhere (Love and Amstutz, 1966), and coarser (5-20 $\mu \mathrm{m}$ diameter) euhedra of pyrite and marcasite that probably formed by recrystallization of smaller crystals. Study by scanning electron microscope and high-power reflecting microscopy reveal only traces of sulfide minerals other than pyrite and marcasite; rare grains of electrum have been found and probably explain the gold in these rocks. These sulfide textures are normally found in black shales but are extremely rare in volcanic-hosted, epithermal systems. The pyrite morphology probably reflects an unusual degree of supersaturation (Murowchick and Barnes, 1987), and may require a metastable iron monosulfide or liquid sulfur precursor (Raiswell, 1982; Graham and Ohmoto, 1992).

Supergene Ore. The upper part of the Sleeper deposit has been modified by supergene processes that redistributed gold into uncemented fractures and voids; silver was leached from electrum and redeposited as halide minerals (Nash and others, 1991). Electrum in samples from the upper $30 \mathrm{~m}$ of the veins typically has rims that are gold-rich $(86 \mathrm{wt}$. percent $\mathrm{Au}, 14$ wt. percent $\mathrm{Ag}$ ) and intergrown with cerargyrite $(\mathrm{AgCl})$, and cerargyrite fills late fractures and vugs. Extremely rich samples of gold with moss texture that formed in voids and fractures indicate that gold was mobile at millimeter to meter scales. Despite clear evidence for mobilization of silver and gold, bulk Ag:Au ratios (as in blasthole assays) do not change appreciably in the upper, oxidized portion of the orebody, and no evidence has been found for an enrichment blanket.

Alluvial Ore. Tertiary conglomerate in the western part of the Sleeper pit contains significant amounts of alluvial gold. Approximately $100,000 \mathrm{oz}$ of gold was recovered in 1990-1992 from zones averaging about $0.1 \mathrm{oz} /$ ton. Gold in the weakly consolidated sedimentary rocks was recognized during pre-development reverse circulation drilling. The gold-rich zones are poorly sorted and contain clasts 10 to 30 $\mathrm{cm}$ in diameter, chiefly altered Sleeper rhyolite. The most distinctive clasts are white banded silica rock and silicified rhyolite with stockwork veinlets of silica and pyrite. Visible electrum was commonly present, and some spectacular samples contained about 10 percent electrum in banded opaline silica (clasts of bonanza gold vein). The west-trending deposits fill channels cut into Sleeper rhyolite immediately west of one or more normal faults. The gold-rich sediments were deposited from aqueous systems, although the very coarse, poorly sorted ones resemble debris flows. In terms of deposit classifications (Boyle, 1979), these probably are the gulch- and creek-type of alluvial placer deposits, but some zones are similar to elluvial placers in which gold is moved 
chiefly by gravity and downhill creep. The gold-rich zones are clearly only a short distance west of the Sleeper vein, and many clasts are mineralogically and texturally identical to samples from the Sleeper vein.

Recent Developments. Geologic studies and drilling in 1993-1994, after most of this report was written, have documented several new ore zones that will be mined in the final phases of the Sleeper mine. (1) Drilling at the northeast end of the pit (near $9500 \mathrm{~N}, 7000 \mathrm{E}$, pl. 2) has encountered veinlike deposits in intermediate lavas east of the major basin-and-range fault that generally has been the eastern limit of veins in Sleeper rhyolite. Quartz-gold veins in this area are not banded as in the Sleeper vein nearby (but in the hanging wall of the fault), and megascopically resemble barren, massive quartz veins in Sleeper rhyolite. (2) A zone of breccia west of the Wood sub-pit (mine coordinates $5800 \mathrm{E}, 6800 \mathrm{~N}$, pl. 2) has been drilled and found to increase in size and grade at depth. (3) The Office Pit zone has been found to extend deeper and farther east than indicated by earlier drilling; the Office Pit zone has a unique N. $70^{\circ} \mathrm{W}$. azimuth between two faults of this orientation. The Office Pit zone ores also have unique composition and texture: they have high $\mathrm{Ag}$ and pyrite content typical of breccias elsewhere, but contain abundant clear quartz that is more veinlike than that in typical breccias. (4) Two zones of heap-leach grade ore have been defined east of the pit and will be mined as small satellite pits in the final stages of mining. These zones are in silicified Sleeper rhyolite. Numerous drill holes in metasedimentary rocks below rhyolite and cropping out east of the range-front fault in this area have encountered only thin zones of low-grade gold mineralized rock. These developments were made by infill drilling on $25-\mathrm{ft}(7.6-\mathrm{m})$ centers in areas previously drilled on 100 or 200 -ft centers, and by changing drill angle and azimuth to better intersect northwest-trending structures. The new reserves will be announced early in 1995 in the AMAX Gold Inc. annual report.

\section{GEOCHEMICAL ZONATION}

\section{HYDROTHERMAL ALTERATION}

Hydrothermal alteration is systematically developed in time and space relative to the gold-silver deposit. Time relations are somewhat ambiguous because alteration at Sleeper generally is diffuse, with gradational boundaries, rather than sharply bounded with alteration selvages that can be related to specific fractures or veins as in many base-metal systems (Meyer and Hemley, 1967). Spatial aspects of alteration (pl. 2) can be mapped in general, but differences among finegrained alteration products such as sericite, clays, alunite, and opal are subtle under the hand lens and require study by thin section or X-ray diffraction, thus can only be tentatively mapped in the field. Alteration relations are most effectively demonstrated within just one rock type, Sleeper rhyolite, because alteration character changes significantly according to the initial bulk composition of the rock. Thus, alteration mineral assemblages in the more mafic rocks are generally distinct from those in rhyolite. Also, the physical character of the rock, such as brittle or soft, massive, layered, or vesicular, glassy or crystalline, phenocryst or groundmass, had an important role in alteration reactions.

Progressive chemical and mineralogical changes define six types of alteration:

1. Devitrification, or perlitic alteration (fig. 19A-C) in which glassy matrix is modified from black to white by addition of water, crystallization of spherulites, and formation of opal and small amounts of pyrite ( $<1$ percent). Devitrification in most of the Sleeper rhyolite was not related to ore-forming fluids, but ore-related alteration was superimposed on it with gradational effects.

2. Argillic alteration, in which smectite and other very fine grained clays replace chiefly groundmass and lesser plagioclase, in reactions that probably followed curving planes of perlitic alteration. Minor amounts ( $<2$ percent) of fine-grained pyrite-marcasite were added (fig. 19C). Details of this alteration are poorly documented because the rocks are friable and difficult to process for thin sections. Binocular microscopic observations on crushed samples suggest that the textures evolved in the same manner as during devitrification of glassy Sleeper rhyolite, and only a few percent of clay was formed. The rocks are friable, but the granular pieces are hard, probably reflecting formation of opal in glass.

3. Silicification, in which opal or micro-quartz replaces plagioclase (fig. $34 A$ ), plagioclase plus groundmass, and ultimately sanidine. Fine-grained pyrite-marcasite was added in small to moderate amounts (1-5 percent).

4. Sericitic alteration, in which sericite replaced plagioclase, groundmass, and sanidine, respectively (fig. 34C), as intensity increased. Fine-grained pyrite-marcasite was added in moderate amounts ( $2-5$ percent).

5. Acid-leach alteration, in which plagioclase and ultimately the groundmass were leached to a spongelike texture and the voids filled or coated by powdery mixtures of opal, kaolinite, and alunite.

6. Supergene alteration, chiefly oxidation, that is related to the Miocene-Pliocene erosional and weathering surface or surfaces, and that formed limonite, jarosite, kaolinite, and other minerals.

Several general spatial attributes of alteration are evident now that mining has exposed deeper and wider parts of the system. These generalizations are based on megascopic features of pit faces, behavior in blasting, or observations from a distance (that often are more pertinent than details). Silicification of Sleeper rhyolite generally decreases at the ends and sides of the orebody and also decreases downward (which was not anticipated). 

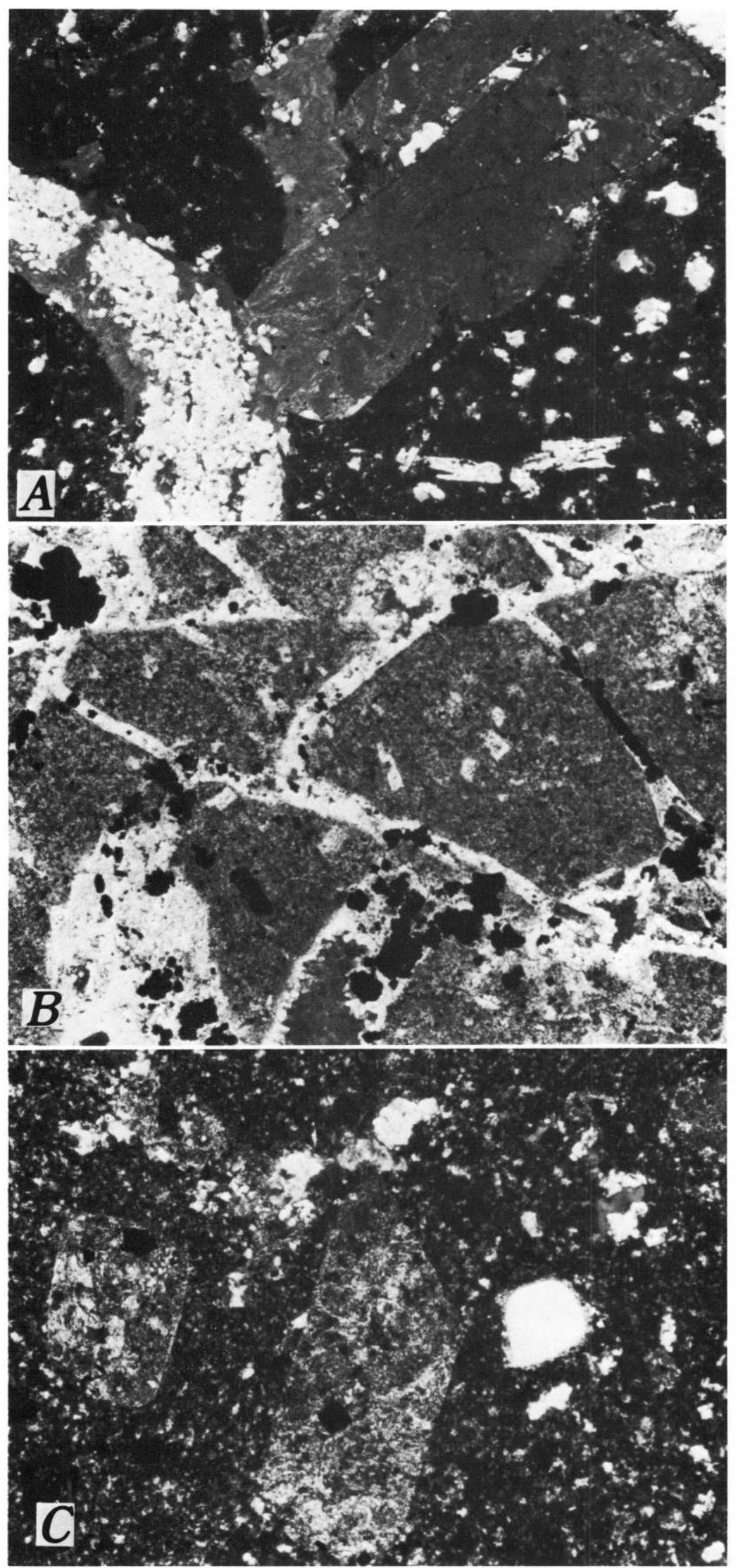

$0.5 \mathrm{~mm}$
Figure 34. Photomicrographs of ore-associated alteration of Sleeper rhyolite. $A$, Silicification near Wood vein in which plagioclase is replaced by tan opal; groundmass is mostly opal (black, isotropic); a veinlet is filled by opal and microquartz that is anisotropic. Crossed polarizers. $B$, Stockwork veinlets in opal-altered rhyolite. The veinlets are filled by translucent micro-quartz (anisotropic) plus pyrite and marcasite; the dark, opaline groundmass is isotropic under crossed polarizers. Parallel light. $C$, Silica-sericite alteration of rhyolite in which plagioclase is replaced by fine white mica, and groundmass is altered to silica-sericite mass that is so fine grained that it is barely birefringent. Crossed polarizers. 
Silicification grades almost imperceptibly across 10 to $30 \mathrm{~m}$ into softer, argillized rocks, and there is no evidence for gradation downward into chloritic alteration. Quartzsericite-pyrite (QSP) alteration of the more mafic rocks (intermediate lavas and lapilli tuff) likewise is variable in its intensity and extends beyond the pit limits laterally. This alteration does not increase downward, in part shown by virtually fresh feldspars in pyritized lavas upfaulted along the basin-and-range faults and exposed at the bottom of the Sleeper and Wood sub-pits. The amounts of pre-ore and orestage pyrite and marcasite in silicified- and QSP-altered rocks determine the colors and mineralogy of superimposed supergene alteration (as is well known in porphyry copper systems (Anderson, 1982)) and provides a useful guide to mapping primary alteration and rock types. Acid leach alteration, accompanied by powdery opal, kaolinite, alunite, or native sulfur, decreases in abundance and intensity below the late-Tertiary unconformity and is a minor alteration type more than $50 \mathrm{~m}$ below the unconformity.

Alteration Zones in Sleeper Rhyolite. The essentially uniform chemical and mineralogical composition of this rock, previously described, provides a good basis for discussing alteration zonation. The general time sequence was: (1) early silicification, as opaline silica and probably gradational with devitrification of glassy matrix; (2) vein and stockwork stages of silicification associated with ore deposition; (3) post-ore acid leaching under oxidizing, near-surface conditions but possibly by warm fluids rather than cold supergene ones. The post-ore alteration will be considered in a later section.

Spatially, the early stage silica graded outward into argillic alteration, with a narrow interface a few meters wide of sericitic alteration between the silica and argillic alteration. We cannot define exactly how much silicification was pre-ore and how much developed during later ore stages. Because both vein-type and breccia/stockwork-type ores occur exclusively in silicified rocks (or quartz-sericite alteration), and one can see quartz veinlets cutting silicified rock, we postulate that the ore zone was the site of pervasive silicification somewhat before the ore stage. Typically, the early silicification was opaline silica that replaced aphanitic groundmass, which possibly was still partly glassy. In places plagioclase phenocrysts are replaced by microcrystalline quartz, probably also early stage; the difference in crystallinity relative to groundmass opal may reflect kinetic effects rather than differences in time or temperature. Another product of early silicification was microquartz-pyrite/marcasite stockworks that lack significant $\mathrm{Ag}$ and $\mathrm{Au}(<0.01 \mathrm{oz} / \mathrm{ton}$ $\mathrm{Au})$. We cannot define specific faults or veins that controlled the introduction of early silica, but suspect an ancestral north-trending fracture zone in the approximate location of the Sleeper and Wood veins.

Silicification produced large chemical changes (figs. 22 and 23). Concentrations of $\mathrm{CaO}$ and $\mathrm{Na}_{2} \mathrm{O}$ are greatly reduced, to less than 30 percent of the original amounts (table 2), and the trace elements $\mathrm{Ba}, \mathrm{Ce}, \mathrm{La}, \mathrm{Nb}, \mathrm{Nd}, \mathrm{Sr}$, $\mathrm{Th}$, $\mathrm{Y}$, and $\mathrm{Yb}$ are much lower than in freshest Sleeper rhyolite. Concentrations of $\mathrm{Al}_{2} \mathrm{O}_{3}, \mathrm{TiO}_{2}$, and $\mathrm{P}_{2} \mathrm{O}_{5}$ are only slightly changed, and the increase in $\mathrm{SiO}_{2}$ (from 71 wt. percent to 75 wt. percent) is less than suspected from the major change in appearance and silicate mineralogy. Concentrations of $\mathrm{Cu}$, $\mathrm{Cr}, \mathrm{Mo}, \mathrm{Ni}$, and $\mathrm{V}$ are higher than in freshest Sleeper rhyolite, whereas $\mathrm{Pb}$ and $\mathrm{Zn}$ are lower.

The outer alteration zone in Sleeper rhyolite, argillic alteration, is so diffuse that we lack criteria to define its geologic age. It typically contains small amounts of pyrite/marcasite and broadly spaced veins up to $1 \mathrm{~cm}$ wide filled by micro-quartz and pyrite/marcasite; broad areas of this type of rock are consistently barren $(<0.005 \mathrm{oz} /$ ton $\mathrm{Au})$. These alteration zones rarely contain ore-grade veins, breccias, or stockworks. These relations might be explained in several ways: (1) during early stages, while the rhyolite was glassy, no faults and few fractures cut the brittle rocks; (2) these barren rocks underwent perlitic and argillic alteration prior to ore stages and were mechanically unfavorable for formation of veins, breccia, or stockworks.

Argillized, crumbly Sleeper rhyolite at the south and northwest parts of the Sleeper pit (pl. 2) has not been modified as much as one would guess from its appearance. Relative to the freshest, glassy Sleeper rhyolite, these rocks have nearly the same concentrations of major elements, but $\mathrm{CaO}$ is lower by about 30 percent, $\mathrm{Na}_{2} \mathrm{O}$ is lower by about 60 percent, and $\mathrm{K}_{2} \mathrm{O}$ is lower by about 22 percent (figs. 22, 23; table 2). The trace elements $\mathrm{Ba}$ and $\mathrm{Pb}$ also are lower in the crumbly rocks. These elements probably were originally in both feldspars and glassy matrix; losses could have occurred from either sites, and the losses are notably smaller in magnitude than in silicified Sleeper rhyolite. Concentrations of $\mathrm{P}, \mathrm{Ti}, \mathrm{Ce}, \mathrm{Cr}, \mathrm{Cu}, \mathrm{La}, \mathrm{Nb}, \mathrm{Nd}, \mathrm{Ni}, \mathrm{Sc}, \mathrm{V}$, and $\mathrm{Zn}$ remain approximately unchanged, whereas $\mathrm{Th}, \mathrm{Y}$, and $\mathrm{Yb}$ are lower in the argillized rocks. Base-metal concentrations, in general, tend to be the same or lower in the argillized rocks compared with freshest Sleeper rhyolite, despite the fact that most of the samples come from less than $200 \mathrm{~m}$ of ore.

A narrow intermediate alteration zone less than $10 \mathrm{~m}$ wide, between silicified and argillized rhyolite, contains silicified groundmass and sericitized plagioclase. This alteration is not related to structures and occupies a much smaller volume than the other alteration zones. This intermediate zone appears to reflect diffusion outward from the veins and a chemical environment characterized by transitional values of silica, alkali, and hydrogen activities commonly portrayed as $\mathrm{K}^{+} / \mathrm{H}^{+}$(Rose and Burt, 1979). Similar mineralogical zones along base-metal veins are commonly a few centimeters wide. The broad scale and diffuse character of the zone at Sleeper suggest that chemical gradients (or disequilibrium) were smaller at Sleeper than at classic base-metal deposits such as Butte (Meyer and Hemley, 1967). 
Ore stages of high-grade veins and somewhat later breccias and stockworks are characterized by abundant silica within brittle fractures, but previously silicified wallrocks do not appear to have been changed much. Fine-grained adularia is abundant in banded high-grade gold bands (Nash and others, 1991), present in some breccias, but absent in the enclosing wallrocks. Sanidine phenocrysts generally persist in the silicified rocks; $\mathrm{K}+\mathrm{H}+$ appears to have been high enough to stabilize sanidine but too low for sericite or adularia formation.

Alteration Zones in Intermediate Lavas. These rocks alter in ways that are distinct from the Sleeper rhyolite, in part because of their mafic bulk composition. Early alteration tends to be quartz-sericite-pyrite (QSP); the abundant plagioclase and iron oxides (magnetite?) in the rocks are replaced by abundant sericite and pyrite, respectively. Vesicles are filled by silica, commonly zoned from outer microquartz to central opal. In places, there is so much silica and the rock so very hard that they can be mapped as "silicified" (but the alteration assemblage is still QSP). In many places the juxtaposition of QSP-altered andesite against silicaaltered rhyolite may reflect the additional factor of later fault displacement. The altered intermediate rocks tend to contain more pyrite than altered rhyolite, commonly 3-8 percent as compared to about 2 percent in rhyolite.

Ore-bearing intermediate rocks tend to be more silicified than nearby barren ones. It is not clear whether this is cause or effect. Possibly zones of more intense early silicification were brittle and broke more effectively during later fracturing and were permeable for ore-bearing fluids. Intermediate rocks that are not highly silicified tend to contain relatively low grade ore of the Ag-rich, sulfidic type, but stockwork veinlets are not well developed.

Some peripheral alteration zones in andesite and basalt contain an assemblage of calcite-chlorite-pyrite. Calcite replaces plagioclase, and mafic minerals and aphanitic matrix are altered to chlorite plus pyrite (to more than 5 percent). It has not been recognized in outcrop or open pit, and visual estimates tend to underestimate the amount of chlorite, calcite, and pyrite, especially in drill cuttings. Distribution is incompletely known; it has been identified in thin section study of rocks from five drill cores. This alteration has not been seen in Sleeper rhyolite, and always is $>200 \mathrm{~m}$ from ore; thus its age is moot. It could be older or younger than any alteration in rhyolite, or it could be part of the same general system that altered rhyolite and emplaced ore. This alteration assemblage is similar in some aspects to widespread propylitic alteration in andesitic volcanic rocks adjacent to base-metal veins as in the San Juan Mountains, Colo. (Meyer and Hemley, 1967), but it lacks the epidote and crystallinity of those higher temperature systems. Later we speculate on the possibility that the high iron and sulfur of this environment may be the same age, or be remobilized to form the Fe-S rich breccia-stockwork ores.
Post-ore Supergene(?) Alteration. Several types of oxidative alteration are observed along post-ore structures or below the Quatemary unconformity. Most of this altered rock has been removed by mining, and because this alteration does not appear to produce any enrichment in $\mathrm{Ag}$ or $\mathrm{Au}$ it is not shown on the geologic map (pl. 2). Four assemblages can be defined: (1) Red to reddish-brown or purple, hematitic alteration in Sleeper rhyolite related to oxidation of pyrite. Various stages and intensities are observed; often red coloration is developed on fracture surfaces through pyriticsilicified Sleeper rhyolite. The most intense alteration of this type is in the $35 \mathrm{~m}$ below the unconformity, but narrowing fingers of red continue down for more than $75 \mathrm{~m}$ below the unconformity. (2) Tan to yellowish alteration, reflecting limonite and jarosite, in weathered intermediate flows and in argillic-altered Sleeper rhyolite. This alteration is similar to (1) (hematite), reflecting oxidation of pyrite, but under somewhat different sulfide:rock ratios (Anderson, 1982). Differences between type 1 and 2 alteration are so consistent as to provide a basis for preliminary mapping of primary rock types. (3) Acid-leach alteration that creates vuggy, porous textures that tend to be filled by powdery white opal, kaolinite, or alunite. Native sulfur occurs in some of these zones. This alteration, focused along open cross-fractures, is typically only a few centimeters wide; however, a few zones were tens of meters wide. Even the widest zones tapered to nil within $30 \mathrm{~m}$ of the unconformity. Alunite from this environment was dated at 5.4 Ma (Conrad and others, 1993). Only a few of the acid leach zones can be shown on the geologic map (pl. 2) because most have been removed by mining. (4) Banded opaline silica with lesser alunite and jarosite in open fractures or brecciated zones. This alteration resembles type 3 but produces distinctive mammillary opal that could be a replacement of carbonate tufa or travertine. The texture and amount of silica suggest that it formed in a nearsurface hot spring or sulfataric system, below the water table, rather than leaching above the water table that creates residual opaline silica (Schoen and others, 1974; White and others, 1988). All these environments were within $50 \mathrm{~m}$ of the Pliocene surface, probably before Lake Lahontan covered the area, and some may have had a thermal component.

\section{CHEMICAL ZONATION}

Because spatial patterns or zonation in chemical parameters can provide a guide to ore deposits, we made an effort to determine chemical zonation around the Sleeper deposit, knowing that the sampling pattern would be less than ideal because of alluvial cover. For this study representative samples of core or cuttings were obtained from drill holes penetrating the Sleeper rhyolite outside of the pits. Samples were classified according to general alteration character: (1) fresh, including glassy and little-altered rocks; (2) oxidized or weathered, typical of the upper $70 \mathrm{~m}$ of the unit; and (3) 
reduced, silica-pyrite-altered, in the lower part of the unit. Samples of altered wallrock and ore from the pits were included to define the target of exploration. For the purposes of geochemical mapping three subsets were used: (1) a subset of 230 analyses of representative samples of rhyolite (samples of extremely altered rock or certain extremely high values were excluded); (2) a subset for "oxidized" rocks comprising 190 samples, including ore zone samples; and (3) a subset of "reduced" or pyritic rocks (148 samples), including ore zone samples. The data were gridded using an inverse square distance algorithm that utilized a search radius of 183 $\mathrm{m}$ and included 10 nearest neighbors; values were computed for a grid $57 \mathrm{~m}$ between lines. The gridding routine tends to smooth the data, which was desired, but the influence of high individual values still can be discerned. Also, relatively few sites lay in the outer parts of the map area, so plotted contours are only rough approximations near the map border. The contours shown in figure 35 should be considered to be only a general representation of the chemical pattern.

Geochemical maps of Sleeper rhyolite in the mine area (fig. 35), based on 230 samples selected as typical of the sampled area or drill hole, demonstrate some general zonal relations that are consistent with the changes produced by alteration, described earlier. One group of elements, $\mathrm{Ca}-\mathrm{Na}$ $\mathrm{Ba}-\mathrm{Sr}-\mathrm{La}-\mathrm{Ce}$, have generally similar spatial distributions that probably largely reflect the state of feldspars in the rocks. The trends are clear for $\mathrm{Ca}$ and $\mathrm{Na}$ (fig. $35 A, B$ ), with high values distant from the orebody and broad areas of low (depleted) values in and around ore. The concentrations of these elements tend to be highest in fresh rocks distant from ore, and lower peripheral to ore and in ore. Local high values for $\mathrm{Ca}$, Ba (fig. 35C), and $\mathrm{Sr}$ occur near ore, probably reflecting hydrothermal minerals such as calcite and alunite; only small amounts of barite have been recognized at Sleeper. The distribution of $\mathrm{K}$ is complex and not reliably shown on a contour map; although $\mathrm{K}$ is present as adularia and sericite in veins and alteration, total $\mathrm{K}$ in these rocks is not consistently high, nor is there a systematic K-rich halo around the deposit. The distribution of $\mathrm{Li}$ (fig. $35 \mathrm{D}$ ) differs from the other alkali and alkaline-earth elements: it is low in fresh rocks and enriched in parts of the ore zone, especially the southeast comer of the Sleeper sub-pit (which was a center of late-stage acid-leach alteration). Lithium probably resides in a clay mineral such as smectite. The distribution of $\mathrm{Pb}$ and Zn (fig. 35G, $H$ ) in part resembles that of $\mathrm{Ca}$ and $\mathrm{Na}$ in that relatively high values occur in little-altered rocks distant from ore and altered rocks near ore have low (depleted) values; these outer "high" values probably reflect $\mathrm{Pb}$ and $\mathrm{Zn}$ in silicate rock-forming minerals, in contrast to $\mathrm{Pb}$ and $\mathrm{Zn}$ in sulfide and sulfate minerals in the ore zone.

Chalcophile elements are erratically distributed in and around the Sleeper orebody. Concentrations of Ag-As-Cu$\mathrm{Mo}-\mathrm{Pb}-\mathrm{Sb}-\mathrm{Zn}$ reach some of their highest levels in ore, but are not consistently high in ore. Some local high concentrations of these metals occur outside of the orebody. Silver is very low except within $100-300 \mathrm{~m}$ of ore, where it commonly exceeds $10 \mathrm{ppm}$. Arsenic tends to be high in part of the ore zone (fig. 35E), and values of about $200-600 \mathrm{ppm}$ occur within about $200 \mathrm{~m}$ of ore. However, there also are low values peripheral to ore and erratic high values distant from ore that are not obviously related to ore. Base metals such as $\mathrm{Cu}-\mathrm{Mo}-\mathrm{Pb}-\mathrm{Zn}$ are generally low throughout the mine area, but are modestly enriched in ore. Molybdenum (fig. 35F) is more associated with Au than the other base metals, but there is no halo of substantial size outside of ore. For $\mathrm{Pb}$ and $\mathrm{Zn}$ (fig. $35 G, H$ ) zones of low values peripheral to ore appear to contain lower concentrations than in outermost fresh rocks; this intermediate zone of possible depletion may not be analytically or statistically valid and should be tested by more appropriately spaced samples and additional analyses. The highest values for $\mathrm{Pb}$ are in alunite-jarosite (plumbojarosite?) alteration at the southwest corner of the Sleeper sub-pit, a zone of fracture-controlled alteration that appears to be sulfataric. The distribution of $\mathrm{Cu}$ is generally similar to that of $\mathrm{Pb}$ and $\mathrm{Zn}$.

Because the upper $50-100 \mathrm{~m}$ of the Sleeper rhyolite is weathered and oxidized below the late Tertiary disconformity, weathering processes may have modified primary geochemical dispersion patterns. An area south of the Wood pit (fig. 36) was examined more closely to search for systematic differences in chalcophile elements between oxidized (limonitic) and reduced (sulfidic) rhyolite samples. In much of this area, two samples were collected from each drill hole: one representative of the upper oxidized part (45-60 ft below the surface, or about $15-30 \mathrm{~m}$ below the disconformity), and one from the deeper unoxidized part about $90-150 \mathrm{~m}$ below the surface. In general, the geochemical abundances and distribution patterns are similar for the two sample types, but there are some notable differences for $\mathrm{As}, \mathrm{Cu}$, and $\mathrm{Pb}$.

Generalized contour maps (fig. 36A-E) show selected contours for the two alteration types, one showing data for oxidized samples and a second for reduced samples. Results for $\mathrm{Ag}$ (fig. 36A) show that the $2 \mathrm{ppm}$ contours for the two alteration types are very similar, and located a maximum of $600 \mathrm{~m}$ from ore. Higher $\mathrm{Ag}$ concentrations are restricted to the open pit. In detail, the highest values in the oxidized samples are south of the highest values for reduced samples; this apparent discrepancy probably reflects the nature of samples collected within the Wood sub-pit and the lack of vertically paired samples from the pit. The distribution of $\mathrm{Co}$ in oxidized and reduced samples (fig. 36C) is similar, but concentrations are lower in the oxidized samples. Cobalt, thought to be present in pyrite and to reflect the abundance of pyrite, is present in very low concentrations outside of the ore zone and provides no guide to ore despite the presence of a broad halo of pyrite.

Distribution patterns for $\mathrm{As}, \mathrm{Cu}$, and $\mathrm{Pb}$ are similar and show complexities that prevent simple application to exploration. Oxidized samples southwest of the pit contain relatively high concentrations of $\mathrm{As}, \mathrm{Cu}$, and $\mathrm{Pb}$ that are 3-10 

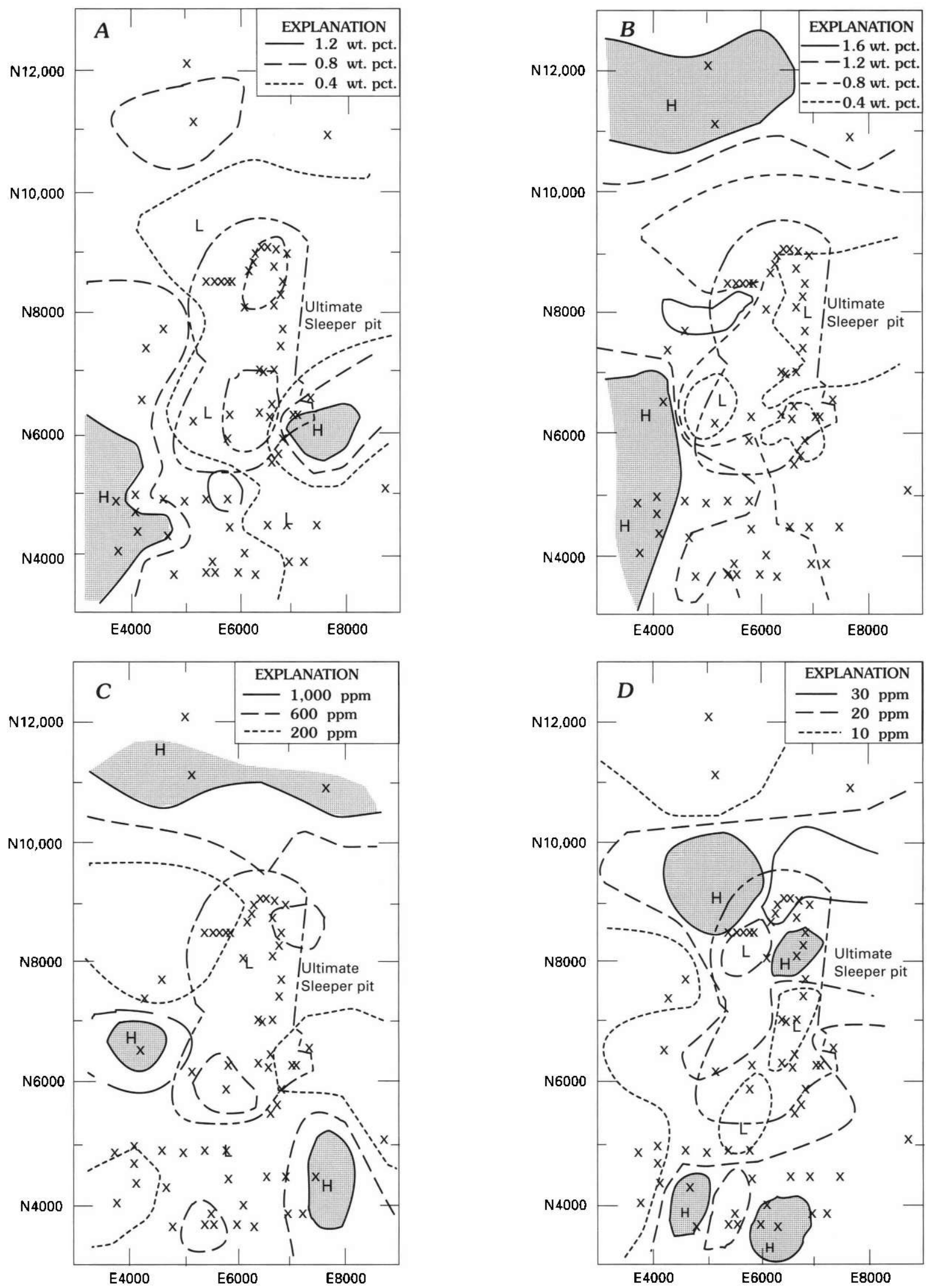

Figure 35. Geochemical maps of Sleeper rhyolite in mine area. Maps based on analyses of 230 rock samples from pit, drill core, or drill cuttings. Outline of ultimate Sleeper pit and sub-pits ( $A$ only) shown for orientation. Mine coordinates in feet. $\mathrm{H}$ and shaded area, high values; $\mathrm{L}$, low values; $\mathrm{X}$, sample locality projected to surface. $A, \mathrm{Ca} ; B, \mathrm{Na} ; C, \mathrm{Ba}, D, \mathrm{Li}$. 

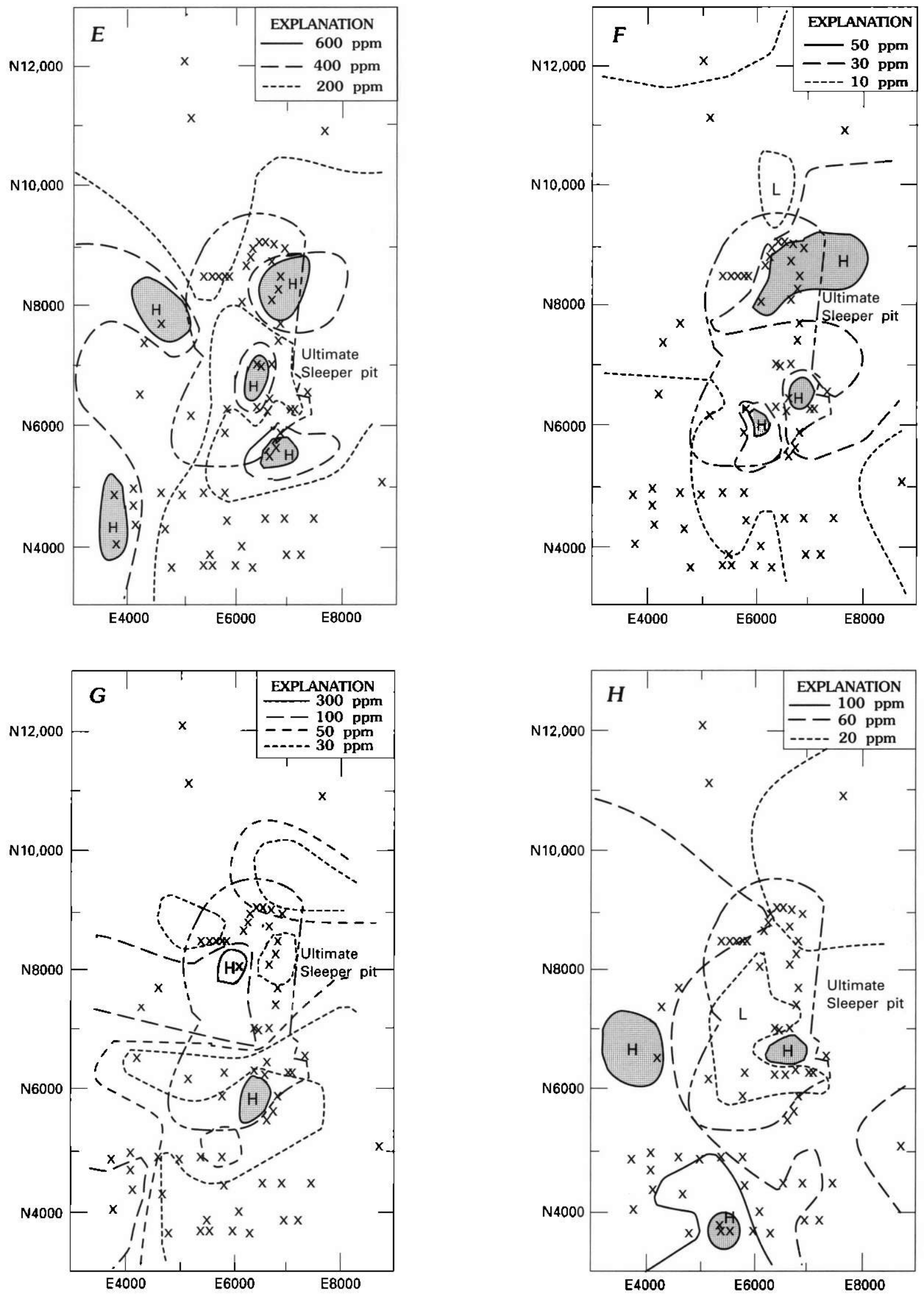

Figure 35-Continued. Geochemical maps of Sleeper rhyolite in mine area. $E, \mathrm{As} ; F, \mathrm{Mo} ; G, \mathrm{~Pb} ; H, \mathrm{Zn}$. 
times that in underlying reduced samples. The anomalous zone appears to be hydromorphically displaced from the ore zone. Arsenic values in oxidized samples are generally $2-4$ times those in underlying reduced rocks across the map area (fig. 36B), suggesting enrichment of some sort in the weathering zone. The halo of high arsenic values more than $600 \mathrm{~m}$ from ore is possibly the best geochemical halo at Sleeper; the anomalous As values are $>50 \mathrm{ppm}$ in reduced rocks and $>200 \mathrm{ppm}$ in oxidized samples. A subtle halo of $\mathrm{Cu}$ may be present at Sleeper, but the fact that highest $\mathrm{Cu}$ values in both oxidized and reduced samples are south of the pit suggests that the $\mathrm{Cu}$ values may not be zoned relative to the goldsilver orebody. Lead, like $\mathrm{Cu}$, reaches its highest values south of the pit, and values in oxidized samples tend to be about three times those in reduced samples.

\section{DISCUSSION}

\section{TECTONIC SETTING}

Extensional tectonics played an important role in creating the volcanic rocks and structures that host the Sleeper orebody. Extensional tectonic regimes and concepts for the Basin and Range province have been described by Stewart (1971), Thompson and Burke (1974), Proffett (1977), Seedorff (1991), and others. Extension is evident in the major late Tertiary structures of the Slumbering Hills and at the Sleeper mine, as well as in the distribution of Miocene rocks. Numerous basin-and-range type normal faults with north to northeast strike reflect east-west extension. Tertiary rocks are generally rotated between normal faults; bedding and compositional layering dip $20^{\circ}-60^{\circ} \mathrm{E}$., and probably average about $40^{\circ} \mathrm{E}$. Normal faults with northwest and northeast strike may have had a strike-slip component. None of the basin-and-range faults (or fault zones) has major displacement compared to others in Nevada, but the aggregate effect of many of the faults was to downdrop the rocks and orebody at Sleeper about $1,000 \mathrm{~m}$ relative to the crest of the Slumbering Hills.

The first evidence for extension in the Slumbering Hills is the lacustrine volcaniclastic rocks comprising debris eroded from the metasedimentary basement (uplifted paleoSlumbering Hills) and possible airfall tuffs. The age of this lake is not known, but it must be older than $17 \mathrm{Ma}$. Evidence elsewhere in Nevada indicates that basin-and-range faulting started at about $17 \mathrm{Ma}$, after widespread 20-25 Ma ash-flow volcanism (Christiansen and McKee, 1978). Early basinand-range faults, evidenced by north-trending dikes, served as conduits for andesitic and rhyolitic magma about $17 \mathrm{Ma}$ and probably controlled the location of tuff-cone vents. We postulate that these normal fault zones were repeatedly active and controlled pre-ore volcanism, hydrothermal alteration and ore fluids, and post-ore movement that is most prominent. Repeated basin-and-range faulting continued to at least 13.6 Ma (post-ore rhyolite), and probably into the late Miocene (5.4-Ma supergene alteration controlled by post-ore fractures). Recent movement along some basinand-range faults is shown by offsets in Quaternary lake beds. Thus, extension-related normal faulting has been episodic from somewhat before $17 \mathrm{Ma}$ to the present.

The combination of Miocene extension and magmatism created a favorable environment for ore formation, and it also played an important role in preserving the shallowformed deposit. Downdropping of the block containing the deposit minimized erosion, which took away only the upper part of the original orebody. The Awakening rhyolite probably flowed over the orebody and provided temporary cover. Cover by Pleistocene and Holocene Lake Lahontan and lake sediments protected the orebody from erosion and oxidation the past several million years.

\section{VOLCANIC SETTING}

The Sleeper deposit formed in a small volcanic field. Rytuba (1989) proposed that Sleeper and other middle Miocene gold-silver deposits of the region formed on the margin of a large shield volcano, but we see little evidence for that in the volcanic stratigraphy as we interpret it. Volcaniclastic sedimentary rocks and intermediate flows filled a local lake, and the flows accumulated in a subaerial environment. Prior to about $17 \mathrm{Ma}$, a local vent erupted pumice and lapilli tuffs in a small tuff-cone slightly northeast of where the Sleeper vein was to form. At about $17 \mathrm{Ma}$ a series of local rhyolite flows erupted from feeder dikes to form a body that was about $3 \mathrm{~km}$ wide (east-west) and perhaps $6 \mathrm{~km}$ long (north-south), and aggregating more than $300 \mathrm{~m}$ thick. The ore-bearing rhyolite body chiefly displays features of lava flows, and there is no evidence that the rhyolite pushed aside any covering rocks, but other bodies of Sleeper rhyolite in the foothills show evidence for domal geometry. At 16.2 Ma, the Steens Basalt erupted about $150 \mathrm{~km}$ to the northwest and created a major shield volcano (Rytuba and McKee, 1984; Rytuba, 1989); the Steens Basalt was very thin in the Slumbering Hills and absent at the Sleeper site. From 16.1 to 15.6 Ma very hot ash-flow tuff fell on the area a few kilometers northeast of the site of the deposit, and probably was deposited on Sleeper rhyolite and was eroded. Periodic movement on basin-and-range faults created open fractures for circulation of hydrothermal fluids. Hydrothermal activity, including some mild explosions, continued from about 16 to 14 Ma, with deposition of gold, silver, and sulfide minerals in veins and breccias. Rhyolite lavas erupted at $13.6 \mathrm{Ma}$ from sources that probably were southeast of the deposit, and distal flows probably covered the orebody.

Volcanism, including local vents and calderas and shield volcanos to the north, created high heat flow in the region from 17 to $13 \mathrm{Ma}$. Drilling in the subsurface discloses only a small number of relatively thin (tens of meters) dikes and sills, 


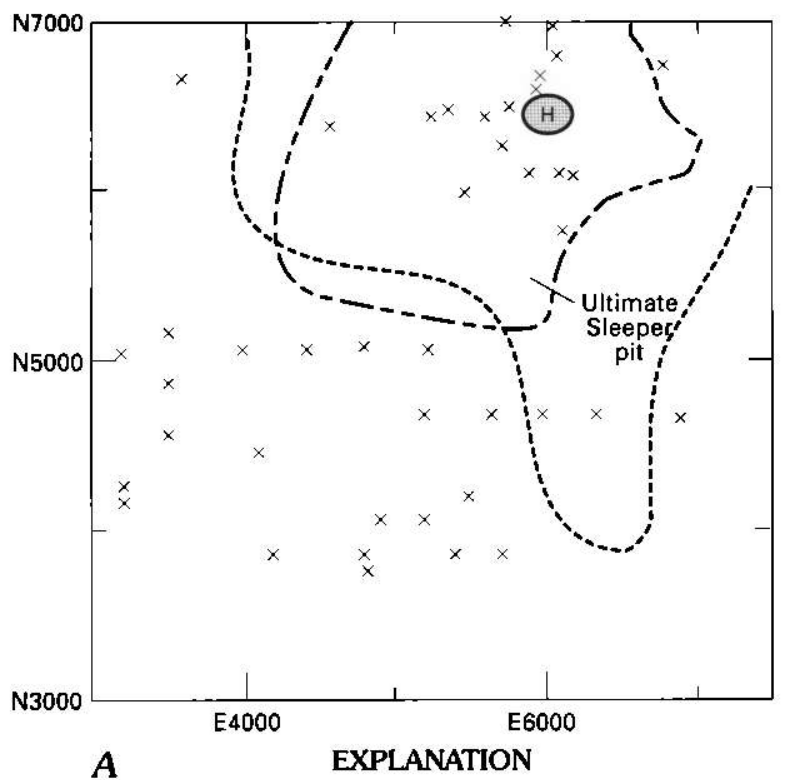

$12 \mathrm{ppm}$ Ag reduced

2 ppm $\mathrm{Ag}$ reduced
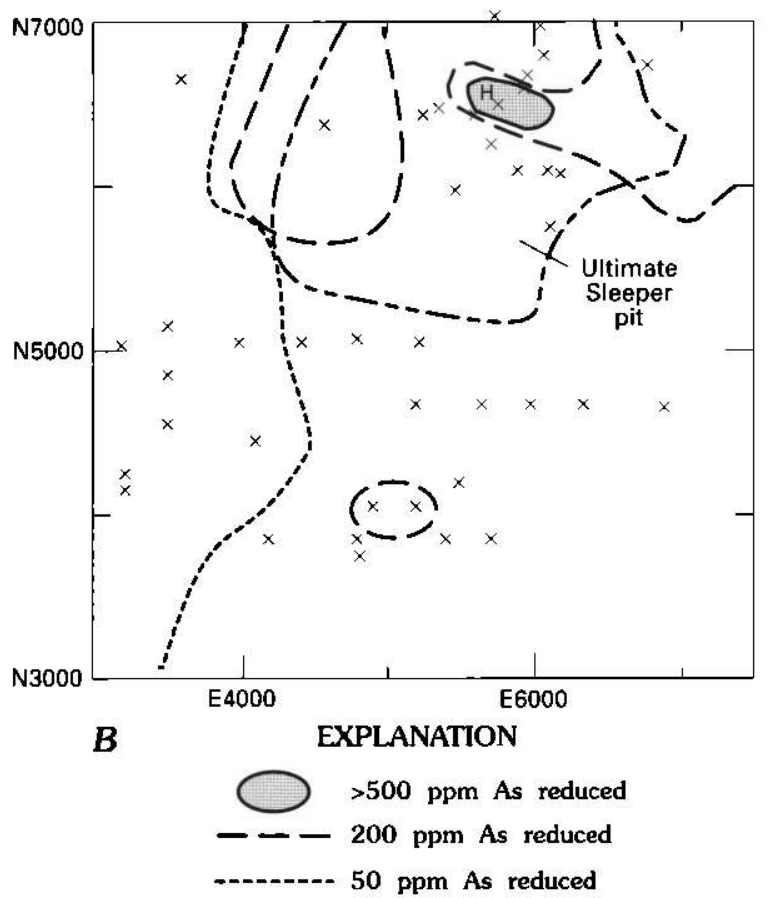
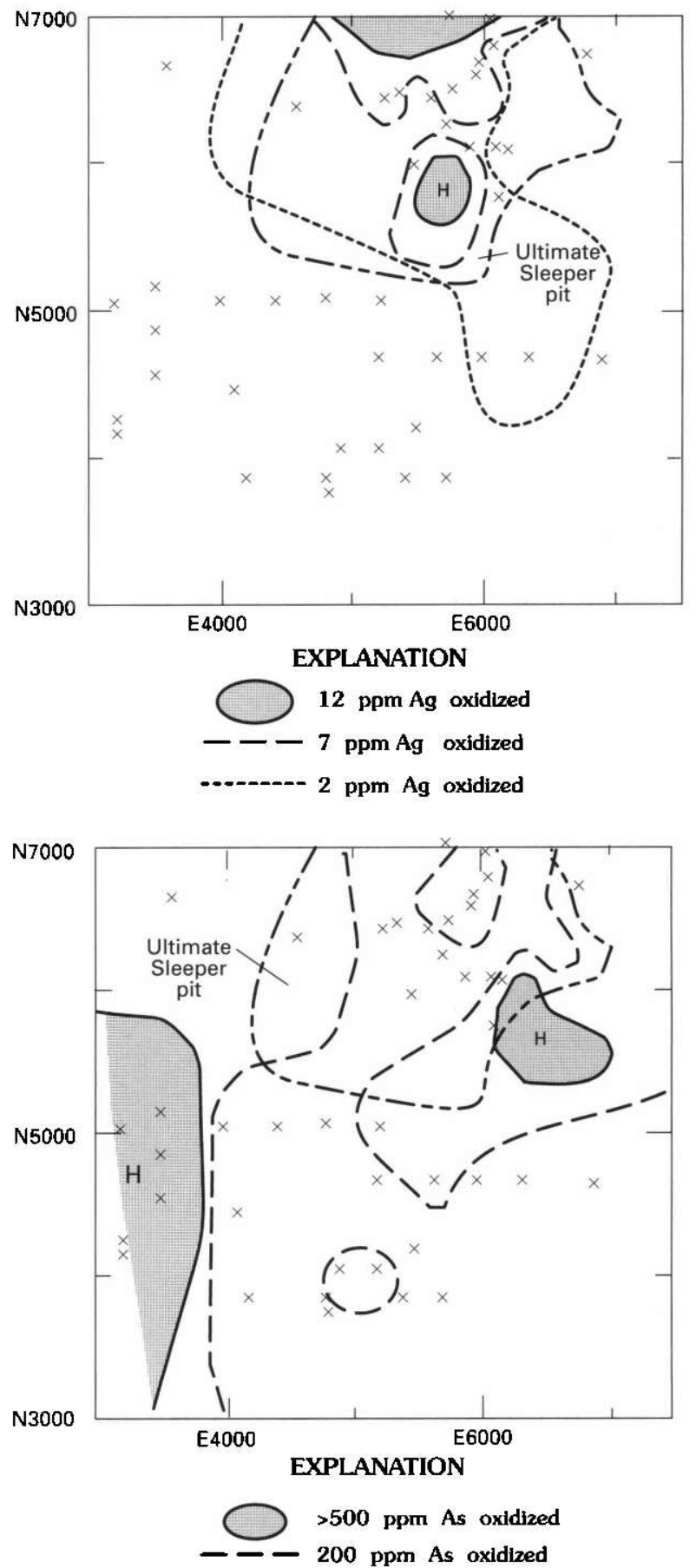

Figure 36 (above and following pages). Geochemical maps comparing reduced (sulfidic) (left view) and oxidized (limonitic) (right view) alteration of Sleeper rhyolite in southern part of mine area. Rock samples are from pit, drill core, and drill cuttings. Outline of ultimate Sleeper pit shown for reference; $\mathrm{H}$, high values; $\mathrm{x}$, sample locality. $A, \mathrm{Ag} ; B, \mathrm{As}$.

and we have no evidence for a stock at depth. The small volume indicated for the intrusions implies that they would have cooled rather quickly, on the order of tens of thousands of years, and would not have been a viable heat source for several million years, as is commonly advocated in pluton-driven hydrothermal systems (Cathles, 1981). If the Sleeper ores formed 1-3 m.y. after eruption of the Sleeper rhyolite (Conrad and others, 1993), most of the heat for the Sleeper geothermal system would have been provided by regional rather than local heat sources. Regional heat flow remains high today in Nevada (Garside and Schilling, 1979) and logically would have been even higher during bimodal volcanism. 

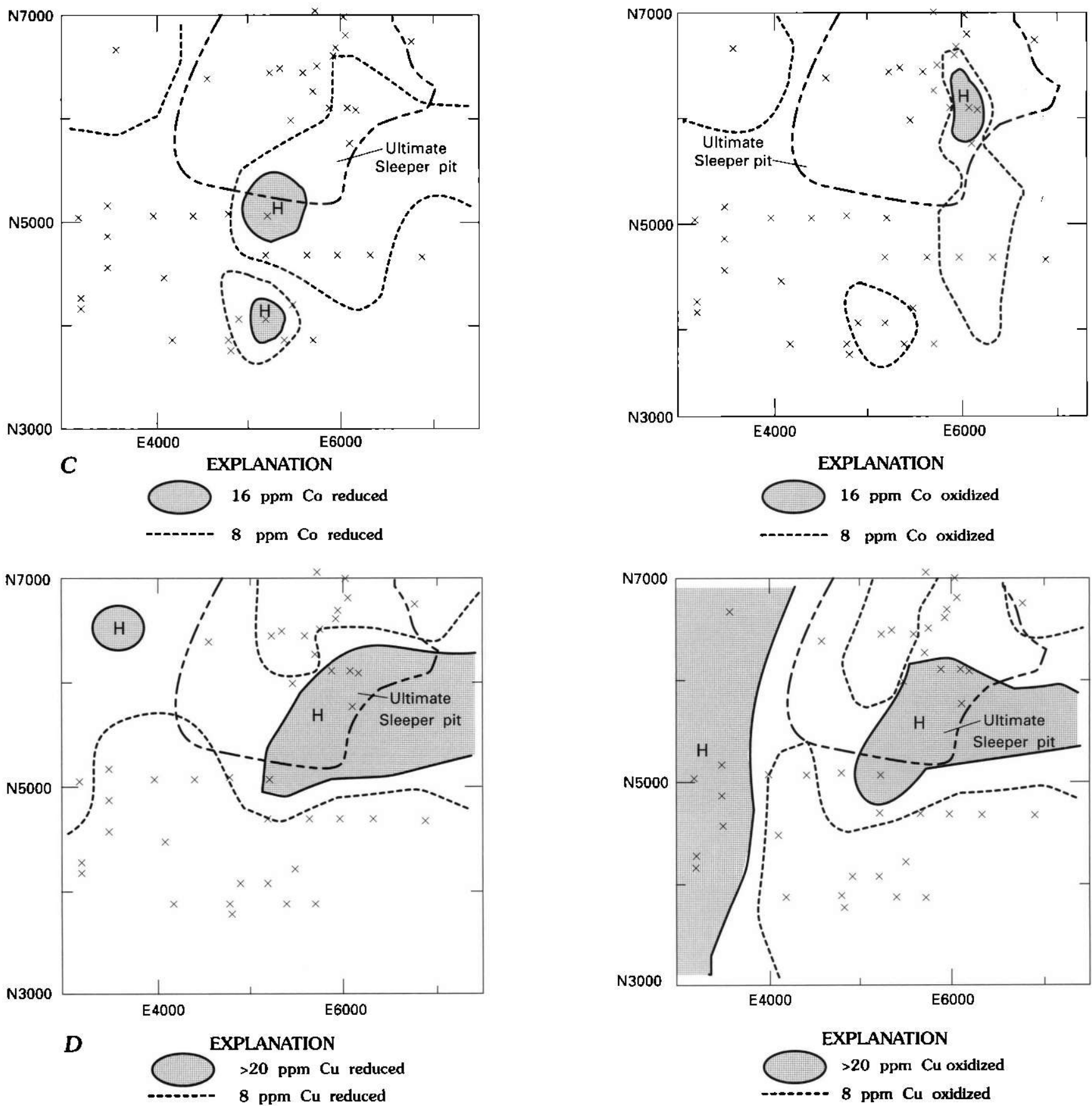

Figure 36-Continued. Geochemical maps comparing reduced (sulfidic) (left view) and oxidized (limonitic) (right view) alteration of Sleeper rhyolite in southem part of mine area. $C, \mathrm{Co} ; D, \mathrm{Cu}$.

Bimodal volcanic rocks of the Slumbering Hills are characteristic of Miocene extensional tectonics in the Basin and Range province. The causes and relations of extension and magmatism remain debated, but that the two are related is not questioned (Gans and others, 1989). In most areas of extension, including the Slumbering Hills, magmatism was in the form of basaltic-andesite and rhyolite flows, whereas calderas formed in areas of little extension. Epithermal ore deposits of gold-silver-mercury are associated with the bimodal volcanic rocks, in both calderas such as McDermitt and noncaldera structural settings such as Sleeper, which has led some (Noble and others, 1988; Conrad and others, 1993) to postulate a major role for bimodal volcanism as the source and driving force in ore formation. The wide distribution of gold-silver deposits in western Nevada that are 14-17 Ma in age (Silberman and others, 1973; Silberman, 1985; Conrad 

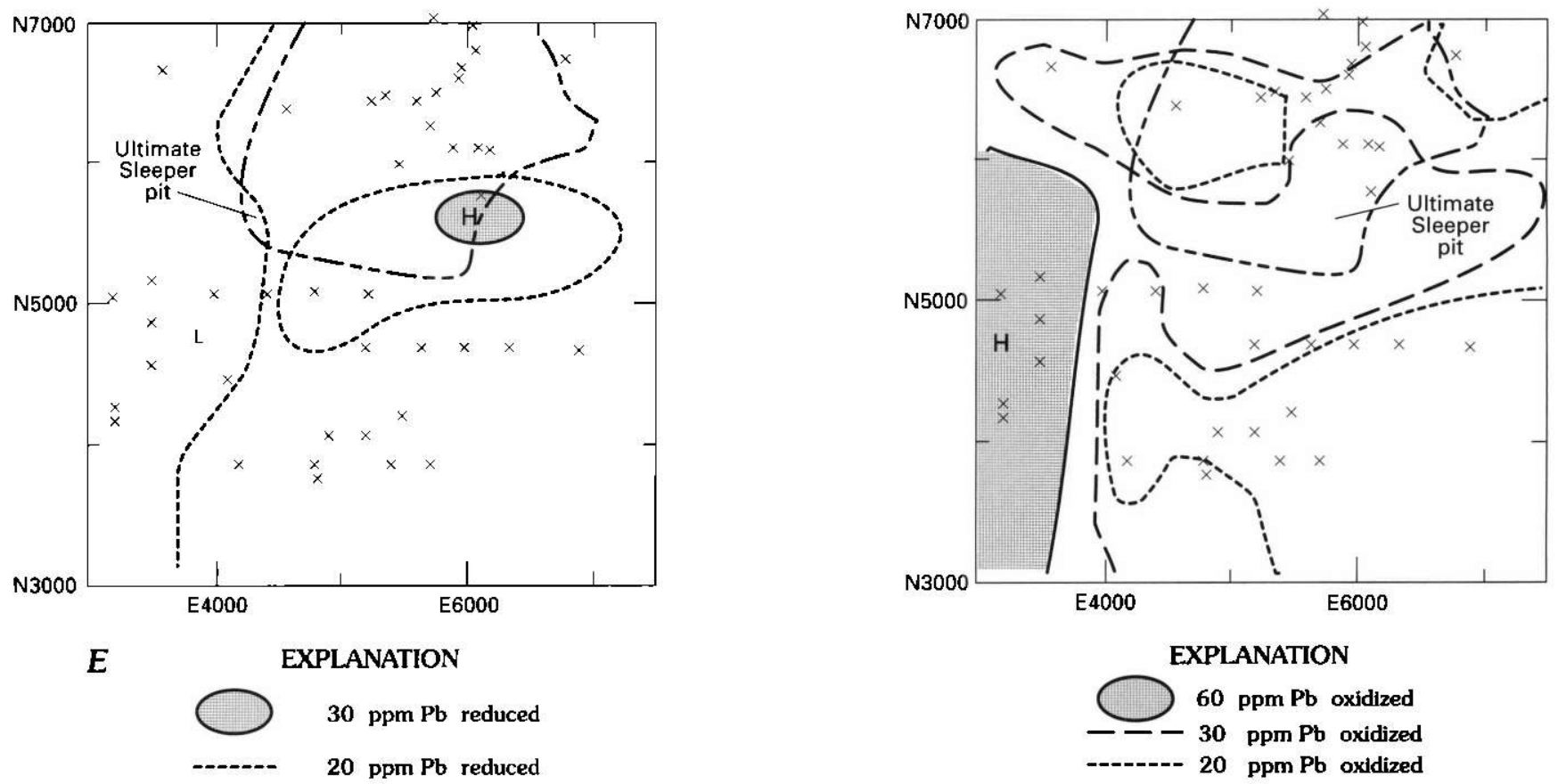

Figure 36-Continued. Geochemical maps comparing reduced (sulfidic) (left view) and oxidized (limonitic) (right view) alteration of Sleeper rhyolite in southern part of mine area. $E, \mathrm{~Pb}$.

and others, 1993) in a variety of pre-Tertiary and Miocene host rocks, many lacking significant Miocene intrusive rocks, leads us to question the importance of bimodal volcanism. In our opinion, the extensional tectonic regime was the primary factor in generating these deposits, as was suggested long ago by Silberman and others (1973) and recently emphasized by Seedorff (1991). The volcanism at Sleeper was a manifestation of regionally high heat flow, rather than a focused heat engine, and probably contributed sulfur but little gold-silver to the deposit.

\section{STRUCTURAL ENVIRONMENT OF ORE FORMATION}

The tectonic and structural setting sketched previously provides a generalized framework for discussing in some detail the structural environment of the ore formation. A short time after extrusion of the thick mass of Sleeper rhyolite ( $<1$ million years, Conrad and others, 1993), pre-ore fractures propagated along an ancestral basin-and-range normal fault zone. A snapshot at about $16 \mathrm{Ma}$ probably would show a simple stack of layered flows, with interbedded volcaniclastic and tuffaceous rocks. The rhyolite body may have still been hot and perlitic alteration had started, but most of the rhyolite was brittle and fractured readily in zones of stress. Thicker flows of the intermediate lavas also were brittle and could sustain open fractures, but tuffaceous rocks were impermeable because they were soft and could not fracture. Hydrothermal fluids circulated through the fractured rocks, depositing silica and pyrite in fractured rhyolite and in permeable zones (fractures, vesicles, flow breccia) in intermediate flows.

Zones of early silicification were favorable for later ore-stages of brittle fracturing and brecciation. Soft clay-rich and perlitic-altered rocks did not fracture and were relatively impermeable to ore fluids, thus received only minor amounts of ore metals. Continued extension from 16 to $14 \mathrm{Ma}$ along the range-front fault zone created open fractures in brittle silicified rhyolite and flows of intermediate lavas. Delicately banded opaline silica and electrum were deposited in the fractures, creating the Sleeper, Wood, and parallel highgrade veins. The banding and widths up to $4 \mathrm{~m}$ indicate that the fractures were sustained for the substantial time required for ore deposition: this required a mechanically delicate balance of either initial extension followed by nearly no movement or gradual opening. The rhyolite body was large enough to be a rigid body in the regional extensional stress field, and the brittle character of the glassy lithology was ideal for fracturing. Other thinner brittle flows enclosed in soft rocks were not favored for large, open fractures. Judging from the shearing along faults in tuffs and volcaniclastic sedimentary rocks, it is evident that much of the stress in flows of intermediate lavas was deflected into those incompetent layers.

Breccias developed in brittle rocks during several stages of explosive hydrothermal eruption before and after vein formation (Nash and others, 1991). These breccia zones 
tend to be spatially associated with the veins, thus probably had some relation to those fracture systems, but are not tectonic structures. The breccia zones are local features, a few meters wide and less than $100 \mathrm{~m}$ long and deep, produced by geothermal overpressure caused by vapor phase separation and expansion (Hedenquist and Henley, 1985a; Nelson and Giles, 1985). Feeder fracture zones and an impermeable or sealed cap rock are basic structural requirements. At Sleeper and elsewhere it is clear that clast-supported breccias, which make good ore, form in brittle rocks. Essentially all hydrothermal breccias formed in silicified rhyolite.

Post-ore faulting occurred along the same general range-front zones as in earlier $\approx 17$ - to 14 -Ma activity but appears to have caused larger displacements. We suspect that the structural grain in the mine area, about $\mathrm{N} .0^{\circ}$ to $\mathrm{N}$. $20^{\circ} \mathrm{E}$., was established at about $17 \mathrm{Ma}$ and reactivated periodically. Cross fractures and faults, at about N. $45^{\circ} \mathrm{E}$. and N. $45^{\circ} \mathrm{W}$., seem to have developed later than the northerly trend, although age relations are ambiguous. Also, there may be a left-lateral component of displacement on the northwest-trending faults. These changes may indicate a rotation in extension direction, but the dominant orientation seems to have been east-west. In the mine area the largest post-ore fault displacements are on the east side of the rhyolite body, which also is the footwall of the silicified vein zones in several places. The silicified rhyolite was shattered by post-ore structures, but major displacement occurred at the margin of the body in less competent rocks. Consequently, the highgrade veins and lower grade stockwork ore zones are displaced only slightly and remain nearly intact, which is very important for mining.

\section{CHEMICAL ENVIRONMENT OF ORE FORMATION}

Mineral assemblages in the various ore stages provide general constraints on the character of ore fluids, but the lack of fluid inclusions in the very fine grained gangue minerals prevents determination of fluid temperatures, pressures, or compositions. The general chemical environment was nearsurface, warm (about $150-200^{\circ} \mathrm{C}$ ), neutral to alkaline $\mathrm{pH}$ as advocated for the class of quartz-adularia-sericite gold-silver deposits (Hayba and others, 1985; Heald and others, 1987; Romberger, 1988). The conceptual ore fluid, deeply circulating meteoric water, probably had very low salinity $(<2 \mathrm{wt}$. percent $\mathrm{NaCl}$ ) as in most modem geothermal systems and epithermal ore systems (for example, Nash, 1972; O'Neil and Silberman, 1974; White, 1981; Henley, 1985; Heald and others, 1987). The salinities determined for ancient systems using freezing point depression measurements may err on the high side if the contribution of $\mathrm{CO}_{2}$ is not taken into consideration (Hedenquist and Henley, 1985b). Thus many ancient fluids probably had even lower salinity than stated in the literature, less than $1 \mathrm{wt}$. percent, as in modern systems.
Some qualitative mineralogical features at Sleeper provide a framework for geochemical interpretation and comparison with other precious-metal systems: (1) gangue minerals are unusually fine grained throughout most of the deposit, and are discernibly coarser only in deeper veins ( $>350 \mathrm{~m}$ below the current surface), where they still are finer than in most deposits of this class; (2) a remarkable shift is evident from iron-poor, sulfide-poor vein mineralogy to breccias and stockworks rich in $\mathrm{FeS}_{2}$; (3) the veins are continuous over long horizontal and vertical dimensions, on the order of $600 \mathrm{~m}$ by $300 \mathrm{~m}$ respectively, as in many classic epithermal systems of the San Juan Mountains, Colo. (Nash, 1975; Casadevall and Ohmoto, 1977), and Republic district, Washington (Full and Grantham, 1968). Sleeper is an epithermal deposit with a significant depth dimension, but has many features found in near-surface hot spring systems (Berger, 1985).

The physical conditions of alteration and ore deposition were low pressure and low temperature based on qualitative inferences from mineral assemblages and textures, geologic setting, and analogies to deposits of established setting (Nash and others, 1991). Late Miocene erosion removed only a small amount of cover and mineralized rock. The preserved part of the Sleeper deposit formed in the depth range of about 50 to $500 \mathrm{~m}$, corresponding to about 5 to 40 bars in a hydrostatic system. Preliminary fluid-inclusion studies on rare inclusions of poorly constrained origin suggest that temperatures could have been as high as about $250^{\circ} \mathrm{C}$, but mineralogy and textures suggest disequilibrium and much lower temperature. The formation and persistence of the metastable phases marcasite and opal suggest that ore- and post-ore-stage temperatures did not exceed about $160^{\circ} \mathrm{C}$ (Murowchick and Barnes, 1986). Steam or vapor-phase alteration, commonly advocated in hot springs (White and others, 1988), is not consistent with the dominant silicification at Sleeper because silica is only sparingly soluble in low-density fluids (Foumier, 1985).

The widespread and repeated silicification at Sleeper, involving addition of silica and mobilization of aluminum and alkalis, indicates weakly acidic solutions (Fournier, 1985), whereas deposition of adularia or calcite within veins indicates slightly alkaline conditions 1 or 2 units above neutral $\mathrm{pH}$ (Romberger, 1988). Adularia deposition generally requires an increase in $\mathrm{K}+/ \mathrm{H}+$, which commonly is attributed to boiling or effervescence that releases volatiles such as $\mathrm{CO}_{2}$ and $\mathrm{H}_{2} \mathrm{~S}$, thereby increasing $\mathrm{pH}$, a mechanism that is likely at the shallow levels of the Sleeper deposit. Ideally, fluid-inclusion studies would confirm the boiling scenario. Silicification at Sleeper differs from alteration in most hot springs or epithermal systems in that clay minerals were not formed in abundance. There may be several explanations for this difference, the most likely being the atypically high silica activities at Sleeper. Deposition of opal in veins and pervasively through rhyolite groundmass is evidence for high silica activities and probably 
supersaturated conditions (Fournier, 1985). The cause of the supersaturated(?) solutions is devitrification and alteration of glassy rhyolite groundmass. Banded opal in veins and opal replacement of groundmass, both resembling siliceous sinter in hot spring siliceous sinter terraces, occurs up to $300 \mathrm{~m}$ below the current surface at Sleeper, probably because solutions were unusually rich in silica.

Breccias and related stockwork veinlets that formed both before and after high-grade veins are compositionally distinct from the veins: they contain much more $\mathrm{Fe}$ and $\mathrm{S}$ as pyrite and marcasite, less adularia, and the post-vein breccias are rich in $\mathrm{Ag}$ and have high $\mathrm{Ag}$ :Au ratios relative to the bonanza veins. Transport and depositional conditions were weakly acidic (Meyer and Hemley, 1967; Murowchick and Barnes, 1986). Quartz is generally microcrystalline in breccias and stockwork veinlets, suggesting that temperatures may have been slightly higher than in the veins characterized by opal (Fournier, 1985). This ore type contains substantial amounts of $\mathrm{Ag}$, up to about $5 \mathrm{oz} / \mathrm{ton}$, and economically important amounts of $\mathrm{Au}$ in the range 0.02-0.1 oz/ton, but it rarely contains more than about $200 \mathrm{ppm} \mathrm{Cu}$, $\mathrm{Pb}$, or $\mathrm{Zn}$.

Elegant geochemical models of epithermal systems (Heald and others, 1987; Romberger, 1988; Hedenquist, 1991) help explain many features at Sleeper, but do not seem to address several important aspects. Obviously more and better data from fluid inclusions, mineralogy, and isotopes would provide better answers, but in the interim we warn that some unusual features at Sleeper may require unusual geochemical conditions or processes. Models for sources, transport, and deposition of gold must also explain what is not present. For example, any of several possible models advocating a source of gold in basaltic rocks and transport by chloride complexes has a problem explaining the very low $\mathrm{Cu}-\mathrm{Pb}-\mathrm{Zn}$ at Sleeper and in veins below the gold-silver deposit. Depositional mechanisms such as boiling generally cause more minerals than electrum and silica to precipitate. Most geochemical explanations for deposition of the rich layers of electrum also should cause basemetal sulfide deposition. Another fundamental problem is the contrast in iron and sulfide contents of veins and stockworks. The low sulfide content of veins might be explained by boiling, consequent oxidation, and loss of $\mathrm{H}_{2} \mathrm{~S}$ (Drummond and Ohmoto, 1985; Cole and Drummond, 1986). Did the Fe-S rich stockworks form from fluids that carried more ferrous iron than those forming the veins? Different flow paths and mixing of solutions might explain these differences in ore types.

\section{GEOLOGIC CONSTRAINTS ON ENVIRONMENT OF ORE DEPOSITION}

We have summarized in previous sections information gained from mining the Sleeper orebody over the past 6 years and from more than 200 miles of drilling: much has been learned but many problems remain unresolved or enigmatic. Some information, such as fluid-inclusion compositions and temperatures or the original geometry of the Sleeper rhyolite, may never be known. We now attempt to summarize what we judge to be important geologic constraints on conditions of ore formation at about 15-16 Ma, about 1-2 m.y. after emplacement of the rhyolite. We will focus on $\mathrm{Fe}, \mathrm{S}, \mathrm{Si}$, and $\mathrm{Au}$ because those elements are most abundant and variable in the Sleeper ores, while emphasizing the uniformly low concentrations of $\mathrm{Cu}-\mathrm{Pb}-\mathrm{Zn}$. This very qualitative analysis we hope will be refined and quantified by future research.

\section{CLASSIFICATION AND COMPARISON WITH OTHER PRECIOUS-METAL SYSTEMS}

Sleeper does not fit well in most classification schemes of precious-metal deposits. Differences as well as similarities are instructive. First, in reality two ore deposits exist at Sleeper: bonanza veins that are very rich in $\mathrm{Au}$, poor in $\mathrm{FeS}_{2}$, and have $\mathrm{Ag}: \mathrm{Au}<1$, and breccia/stockwork ore that has much lower Au grades (generally $<0.1 \mathrm{oz} / \mathrm{ton}$ ), high $\mathrm{FeS}_{2}$, and $\mathrm{Ag}$ :Au from 3 to 10. Similar dual ore types are known at Round Mountain, Nev., and DeLamar, Idaho. The geologic and geochemical differences in these two ore types are substantial in these mines, yet the literature may not present clear descriptions, in part because of the change in mining methods from old underground stopes along veins to modern bulk mining of veins and stockworks. The setting at Sleeper is seemingly volcanic, yet much of the hydrothermal circulation would have been through underlying metasedimentary rocks. In the simple classification of Nolan (1933), using weight ratio of gold to silver, the Sleeper vein deposit fits the gold-silver class that is characterized by low base-metal content and association with igneous rocks (but Sleeper is much larger than inferred for typical deposits of this class). Sleeper contains Ag-Au selenide and telluride minerals, thus might be placed in the class for that mineralogy, but Se-Te phases are relatively minor contributors to total ore values. Alteration mineralogy, and especially opaline silica, and a minor element suite of As-Sb-Hg are similar to those of hot springs (Wood, 1988), but the veins at Sleeper are mineralized for more than $500 \mathrm{~m}$ downdip, comparable to epithermal deposits in other districts. The volcanic setting, alteration, and vein adularia at Sleeper are similar to many deposits of the quartzadularia class (Heald and others, 1987; Berger and Henley, 1989), but there are important differences as recognized by Albino and Margolis (1991) for a group of Au-rich, basemetal-poor deposits in Nevada.

The Sleeper vein deposit differs in many important ways from the 16 or so well-studied epithermal deposits that are frequently cited as standards (for example, Heald and others, 1987). A major difference is the very low $\mathrm{FeS}_{2}$ and 
$\mathrm{Cu}-\mathrm{Pb}-\mathrm{Zn}$ sulfide content of the Sleeper veins, including their deepest parts. Many of the well-studied deposits, such as Creede, Sunnyside, Finnlandia, Pachuca, and others have 2 to $>10$ percent base metals (Buchanan, 1981; Hayba and others, 1985); these deposits also are much richer in Ag than Au. Sleeper is one of the few Ag-Au deposits that does not contain abundant base metals or show downward enrichment in base metals (Buchanan, 1981; Silberman and Berger, 1985). Ore-associated alteration at Sleeper also differs in that it does not zone outward or downward into chloritebearing assemblages (local zones of chlorite-calcite alteration below Sleeper may not have anything to do with ore). Also, adularia is present over a larger vertical range at Sleeper $(>500 \mathrm{~m})$ than in most deposits. (See, for example, Buchanan, 1981.) The Sleeper veins appear to have much in common with a subset of quartz-adularia deposits (evident in the compilation of Buchanan, 1981; Albino and Margolis, 1991) characterized by minor amounts of base metals, including: Oatman, Ariz.; McLaughlin, Calif. (Lehrman, 1986); Republic, Wash.; DeLamar, Idaho; and Aurora, Bullfrog, Divide (Hasbrouck), National (Vikre, 1985), and Rawhide (Black and others, 1991) in Nevada. Sleeper also shares many features with the Hishikari (Japan) gold deposit (Izawa and others, 1990), including very high Au grades, low basemetal content, and metasedimentary rock basement. From personal observations, we emphasize numerous similarities in vein character and volcanic setting at National, DeLamar, and Republic. We also see similarities to gold-quartzadularia stages at high levels of polymetallic veins in the Western San Juan Mountains, Colo. (Nash, 1975; Casadevall and Ohmoto, 1977) (although these polymetallic deposits raise the complex issue of how stages of gold deposition relate to base-metal sulfide deposition earlier and lower in the system).

The breccia/stockwork ores at Sleeper do not fit current geochemical classifications. We see similarities to the silicification, low gold grade, high $\mathrm{FeS}_{2}$ (before oxidation) but low $\mathrm{Cu}-\mathrm{Pb}-\mathrm{Zn}$, and high $\mathrm{Ag}: \mathrm{Au}$ at Rawhide, Nev. (Black and others, 1991); Wind, Nev. (Wood, 1991); Freedom Flat, Nev. (non-alunite stage; Eng, 1991); DeLamar, Idaho (stockworks; Halsor and others, 1988); and possibly Round Mountain, Nev. (Sander, 1988). Supergene oxidation obscures many relations in all these deposits, and observed alunite (supergene) should not be confused with that in acidsulfate type deposits. The widespread silicic and potassic (adularia, sericite) alteration in these deposits may indicate that they should be treated as a variant of the quartz-adularia class.

Banded opaline silica in veins is texturally similar to that formed in modern sinter terraces at active hot springs such as Yellowstone, Mont., Beowawe, Nev., or New Zealand (Saunders, 1994; Fournier, 1985; Rimstidt and Cole, 1983; Henley and Ellis, 1983). Solubility and kinetic controls on opal nucleation and coagulation have been studied in detail at many of these hot springs; those principles hold for silica at Sleeper that was deposited below the water table. Modern hot springs have other features in common with Sleeper, such as enrichment in volatile elements such as $\mathrm{As}, \mathrm{Sb}, \mathrm{Hg}, \mathrm{Tl}, \mathrm{Ag}$, and Au (Weissberg, 1969; Henley, 1985), but no modern geothermal system has even a fraction of the gold at Sleeper (White, 1981).

\section{THE GEOTHERMAL SYSTEM}

Models of modern and ancient epithermal systems (White, 1981; Henley and Ellis, 1983; Berger and Henley, 1989; Hedenquist, 1991) are helpful analogs for Sleeper, but we note many geologic features at Sleeper that suggest substantial differences. These and other models generally assume a pluton-driven hydrothermal system, which we question for Sleeper because of the paucity of dikes and lack of evidence for a buried stock. Rather, we suggest a broader, regional-scale heat regime created by a period of bimodal volcanism (heat flow remains abnormally high in northwest Nevada; Garside and Schilling, 1979). Focus for the hydrothermal system was provided by normal faults rather than a pluton or stock. The Pleistocene Coso, Calif., volcanic field and modern geothermal system in an extensional domain (Duffield and others, 1980) provide a good analogy, although rhyolitic intrusions, domes, and vents are much more abundant than at Sleeper. Modern geothermal systems in the Philippines and Japan (Reyes, 1990; Hedenquist and others, 1992) are analogs in which structure and topography are known to influence the geometry of isotherms, upflow and recharge zones, boiling levels, and mineral deposition. Open fractures in extensional tectonic regimes provide greatly enhanced recharge, deep circulation, and wallrock exchange (Wohletz and Heiken, 1992; Forster and Smith, 1990). Simulated topographically driven fluid flow in an extensional tectonic regime (Forster and Smith, 1990) yielded fluid temperatures of $65^{\circ} \mathrm{C}$ at a depth of $4 \mathrm{~km}$, a minimum scenario for the Slumbering Hills at $15 \mathrm{Ma}$. Simulation of a system driven by both topography and thermal buoyancy (created by adding a pluton) yielded fluid temperatures of $300{ }^{\circ} \mathrm{C}$ at a depth of 4 to $5 \mathrm{~km}$. Circulation patterns and temperatures determined by stable isotopic studies (Kyser and Kerrich, 1990) of extensional mylonite zones of upper plates in Tertiary metamorphic core complexes demonstrate pervasive exchange with meteoric water at temperatures in excess of $300^{\circ} \mathrm{C}$.

Water in epithermal systems has been demonstrated to be predominantly meteoric in most ancient and modern systems (O'Neil and Silberman, 1974; White, 1981; Hedenquist, 1991; and others), but a small $(<10$ percent) magmatic contribution can be significant chemically and difficult to detect isotopically (Henley and Ellis, 1983; Hedenquist, 1992; Rye and others, 1992). Geologic features at Sleeper, especially the styles of alteration, structure, and volcanism, and comparison with well-studied epithermal 
systems suggest that meteoric water was predominant at Sleeper. In the Sleeper environment, as we interpret it, the contribution of magmatic volatiles probably was small, as suggested by Margolis and others (1991) for a group of epithermal deposits (including Sleeper) characterized by extensional setting and low base-metal content. Magmatic contributions tend to create more extreme chemical and mineralogical compositions, enrichment in $\mathrm{Cl}$ and $\mathrm{SO}_{4}$, alteration such as acid-sulfate-type, and base-metal enriched ores (Hedenquist, 1992; Rye and others, 1992; Spooner, 1993).

The upwelling part of the geothermal system, flowing in structurally permeable normal fault zones, would have evolved as it approached the paleosurface. As in any geothermal system, boiling would have been inevitable at some depth (Berger and Henley, 1989; Hedenquist, 1991). The surface at the time of ore deposition is estimated to have been less than $500 \mathrm{~m}$, and possibly less than $100 \mathrm{~m}$ above the Pliocene erosional surface that truncates ore today. The only Miocene rocks known in the area that could have covered the Sleeper rhyolite at the time of mineralization would have been the rhyolite ash-flow tuffs, less than $100 \mathrm{~m}$ thick. Mineral textures and stabilities suggest that the preserved top of the orebody was very close to the surface. The water table was above the preserved part of the orebody, as indicated by the sulfidic character of breccia/stockwork ore and generally reduced or partially oxidized (minor barite) veins.

\section{GEOCHEMICAL REACTION PATHS AND SOURCES OF METALS}

The conceptual ore fluid, deeply circulating meteoric water with very low salinity (postulated earlier, $<1$ wt. percent $\mathrm{NaCl}$ ), reacted with pre-Tertiary and Tertiary rocks during a circuitous journey (fig. 37). An additional possible source of water could have been connate water in the clayrich volcaniclastic section. Circulation through the fractured rocks was driven by topography and density, probably sufficient to cause convection (for example, Barton and others, 1977; Forster and Smith, 1990). Widespread alteration demonstrates reaction with hydrothermal fluids in three compositionally distinct rock types in the area: (1) metasedimentary rocks containing chiefly sericite, chlorite, feldspars, quartz, and calcite, as well as notable amounts of graphite and pyrite; (2) intermediate-composition lavas that contained abundant plagioclase and $\mathrm{Fe}-\mathrm{Mg}$ in silicate and oxide minerals or glass which are pervasively altered to sericite, chlorite, quartz, and pyrite below the orebody; (3) rhyolite that contained more than 50 percent glassy groundmass and was very reactive in the geothermal environment. A fourth possible contributor, a subvolcanic magma chamber at depth, could have provided volatile elements, especially sulfur, but we see no evidence for a substantial link to magmatism as there is in porphyry- and polymetallic-type deposits.
Reactions in the geothermal system can be estimated from alteration products and fluid compositions could be modelled thermodynamically if constraints could be placed on initial fluid temperature, pressure, oxidation state, and sulfur and chlorine concentrations (for example, Spycher and Reed, 1989). (1) The large volume of metasedimentary rocks and the lack of alteration selvages along veins suggest that fluids equilibrated with them, attaining a neutral $\mathrm{pH}$, low $\mathrm{Eh}$, and more $\mathrm{CO}_{2}$ and methane than in most volcanic-hosted epithermal deposits from reactions with graphite and calcite. Reactions in metapelites may have been similar to those modelled for rocks below Carlin-type systems. (See, for example, Berger and Henley, 1989; Hofstra and others, 1991.) We lack sulfur isotope data to define sulfur sources, but suspect that most sulfur in Tertiary rocks came from a magmatic source. The amount of sulfur and proportions of sulfide and sulfate are difficult to quantify. (2) Reactions in the intermediate lavas and volcaniclastic sedimentary rocks may have involved larger total mass changes than in ore zones. The geometry of this alteration is poorly constrained by drilling (but appears to represent substantially larger volume than the mineralization in Sleeper rhyolite), and the age relative to gold deposition cannot be specified. This alteration clearly added a huge amount of sulfur, and hydrolytic alteration of feldspars must have released substantial amounts of alkalis. Several time and chemical scenarios are plausible. Passage of a reducing water with modest chloride and low HS-could leach and transport iron from these mafic rocks (Barness, 1979; Hemley and others, 1992). Under these conditions other base metals such as $\mathrm{Pb}-\mathrm{Zn}-\mathrm{Cu}$ probably would have been soluble. The problem is transporting a large amount of iron while, apparently, suppressing transport of other base metals. (3) Reactions in Sleeper rhyolite in the $1 \mathrm{~m} . \mathrm{y}$. or so after its emplacement would have been dominated by the unstable glassy groundmass, yielding silica concentrations approximating those of amorphous silica (Ellis and Mahon, 1964; Foumier, 1985). Silica concentrations were much higher than that determined by equilibrium with quartz or cristobalite, which are generally assumed to moderate silica concentrations. The emerging fluids would have been rich in alkalis as well as silica, probably of high $\mathrm{pH}$, but probably low in iron (because the rhyolite is low in iron and reacting fluids probably were relatively oxidized at this level).

There are no unique or provable sources that would have yielded more than 3 million oz of gold for the Sleeper deposit. Although many sources and source mechanisms have been described (Berger and Henley, 1989; Romberger, 1988; and others), we have seen no objective evidence for a source of gold at Sleeper. Source regions and transport mechanisms that are optimum for gold also should yield as much or more base metals, typical of a Creede-type polymetallic epithermal deposit (Barton and others, 1977; Heald and others, 1987). 


\section{DEPOSITIONAL MECHANISMS}

Early basin-and-range structures focused hydrothermal fluids into what was to become the Sleeper deposit. At these shallower depths boiling (or effervescence) started, as in geothermal systems (Henley and Ellis, 1983; Henley, 1985;
Hedenquist, 1991), releasing a vapor phase enriched in $\mathrm{CO}_{2}$ and $\mathrm{H}_{2} \mathrm{~S}$. Also, the deeply circulating chloride water would have encountered silica-laden water coming from water circulating through the rhyolite. This set the stage for deposition, at different times, in bonanza veins and breccia/stockwork zones.

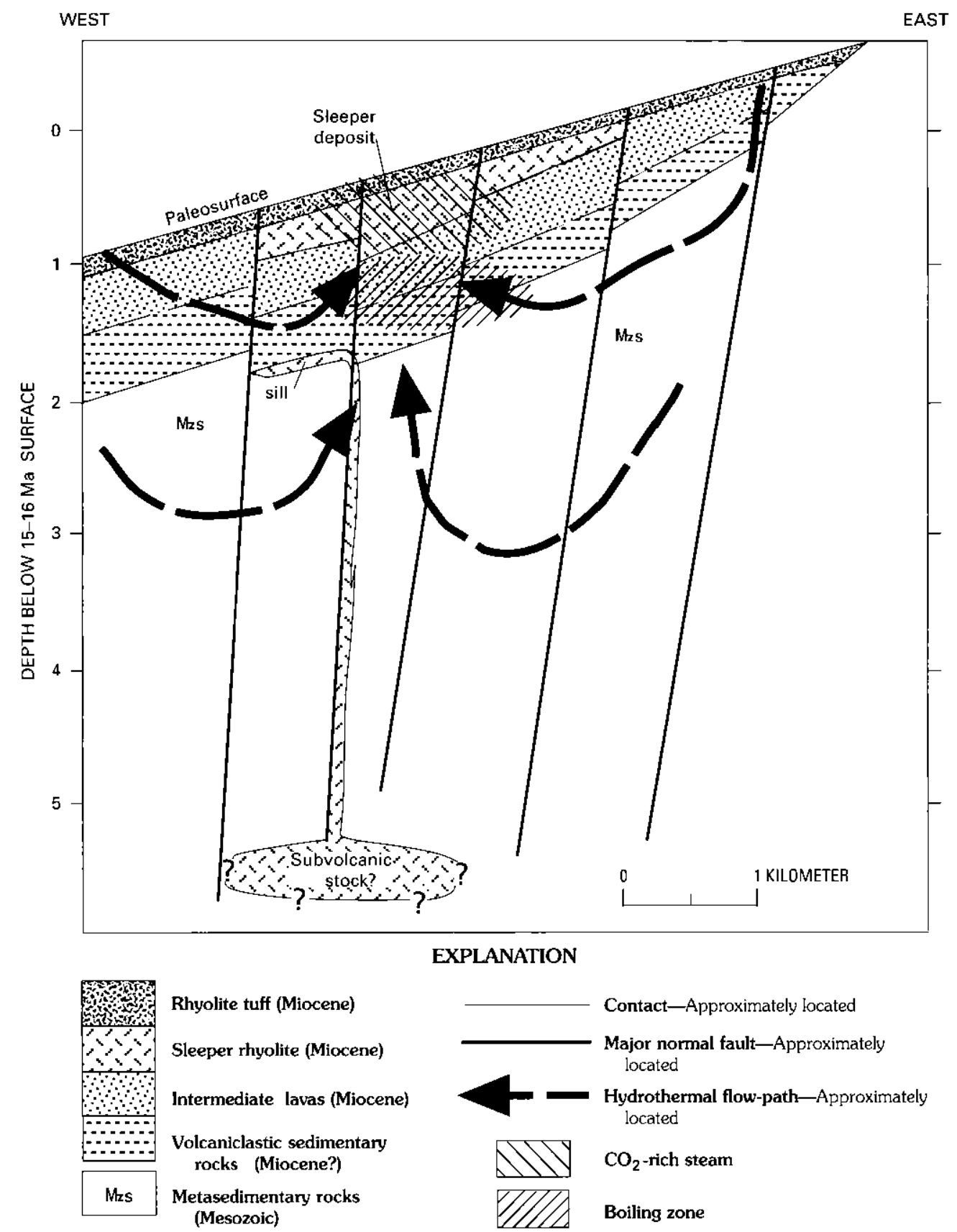

Figure 37. Schematic diagram of Sleeper geothermal system at about 15-16 Ma. Normal faults are shown as growth faults that influenced thickness of volcanic units and created topography similar to that of today. During extension the geothermal system may have been topographically driven. Size and depth of possible magma chamber or stock are queried, not known. Argillic alteration in Sleeper rhyolite and Fe-S-rich breccias and stockworks possibly formed in the mixing zone of $\mathrm{CO}_{2}$-rich steam-heated waters. (Modified from Henley and Ellis, 1983; Hedenquist, 1991; and Forster and Smith, 1990.) 
Bonanza veins. Two processes in open-standing faults may have combined to create the rich gold-opal-adularia fill of the bonanza veins: boiling, and mixing of deep chloride water with silica-rich water (fig. 38). Boiling is inevitable as upwelling hydrothermal solutions rise and pressures decrease (Drummond and Ohmoto, 1985; Hedenquist, 1991). Some permissive, indirect evidence for boiling at Sleeper includes hydrothermal breccias and deposition of adularia, opal, and microcrystalline silica minerals. Consequences of boiling include: loss of $\mathrm{H}_{2} \mathrm{~S}$ and other volatile compounds, rise in $\mathrm{pH}$, oxidation, and cooling, all of which have a strong influence on mineral deposition (Drummond and Ohmoto, 1985; Reed and Spycher, 1985). Boilingrelated effects would have caused specific minerals to precipitate: cooling is most important for silicate minerals, $\mathrm{pH}$ increase is most important for adularia and calcite, and loss of bisulfide and oxidation is most important for electrum. However, the simple mineralogy (opal, electrum, adularia, minor calcite, trace $\mathrm{FeS}_{2}$ ), and especially the tendency for deposition in monomineralic bands (Nash and others, 1991; Saunders, 1990) defy explanation by equilibrium thermodynamic models of epithermal systems. Also, boiling and related effects raise as many questions as they answer, including: why is there so little calcite gangue and so little base-metal sulfide? We suspect that other factors are involved in creating the rare high grades and spectacular bands of gold in the bonanza veins; possible roles of colloidal and mechanical processes are described elsewhere (Nash and others, 1991; Saunders, 1990, 1994).

Fluid mixing, and the cooling effect of boiling, could have induced flocculation of siliceous gels near the base of the vein structures. Fournier (1985) has described hydrothermal reactions in glassy volcanic rocks that can produce hot springs charged with colloidal silica, and in one case, colloidal gold. An analogous situation could have developed at Sleeper by mixing of deep chloride water with waters that had reacted with glassy rhyolite. With cooling, caused by boiling or mixing, silica would coagulate and form a sol. The siliceous gel could then sorb minute particles of gold as it nucleated deep in the vein. The rising sol could then carry the micro-particulate gold in the structure to places where flow and gravitational effects could aid in the concentration of gold (Saunders, 1990). This unorthodox hypothesis is based largely on circumstantial fragments of evidence, but is consistent with behavior of silica, gold, and colloids in hot springs sinter and geothermal scale. (See, for example, Weres and Tsao, 1981; Renders and Seward, 1989.)

Breccia and stockwork ore. Mixing of fluids may provide an answer for iron-sulfide deposition in these structures. Mixing is common in shallow parts of geothermal systems, particularly the intermingling of upwelling liquids and downward-percolating condensates rich in $\mathrm{CO}_{2}$ and $\mathrm{H}_{2} \mathrm{~S}$ (Hedenquist, 1991). These fluids tend to be very dissimilar chemically, and mixing can produce dramatic reactions. Proof of these mixing processes is generally difficult to see in ancient deposits, and certainly is obscure at Sleeper. By analogy to modern geothermal systems and to thermodynamic models (Hedenquist, 1991; Spycher and Reed, 1989), two situations at Sleeper might be explained by mixing of upwelling neutral chloride water and acidic steam-heated ground water: (1) Fe-S-rich breccias and stockworks, and (2) stibnite-rich stages of breccias and veins. The presence of local zones of paragenetically late stibnite is puzzling at Sleeper: they are virtually monomineralic stibnite and lack associated $\mathrm{Au}, \mathrm{Ag}$, or $\mathrm{Cu}$ minerals. Calculations (Spycher and Reed, 1989) suggest that one of the few effective ways

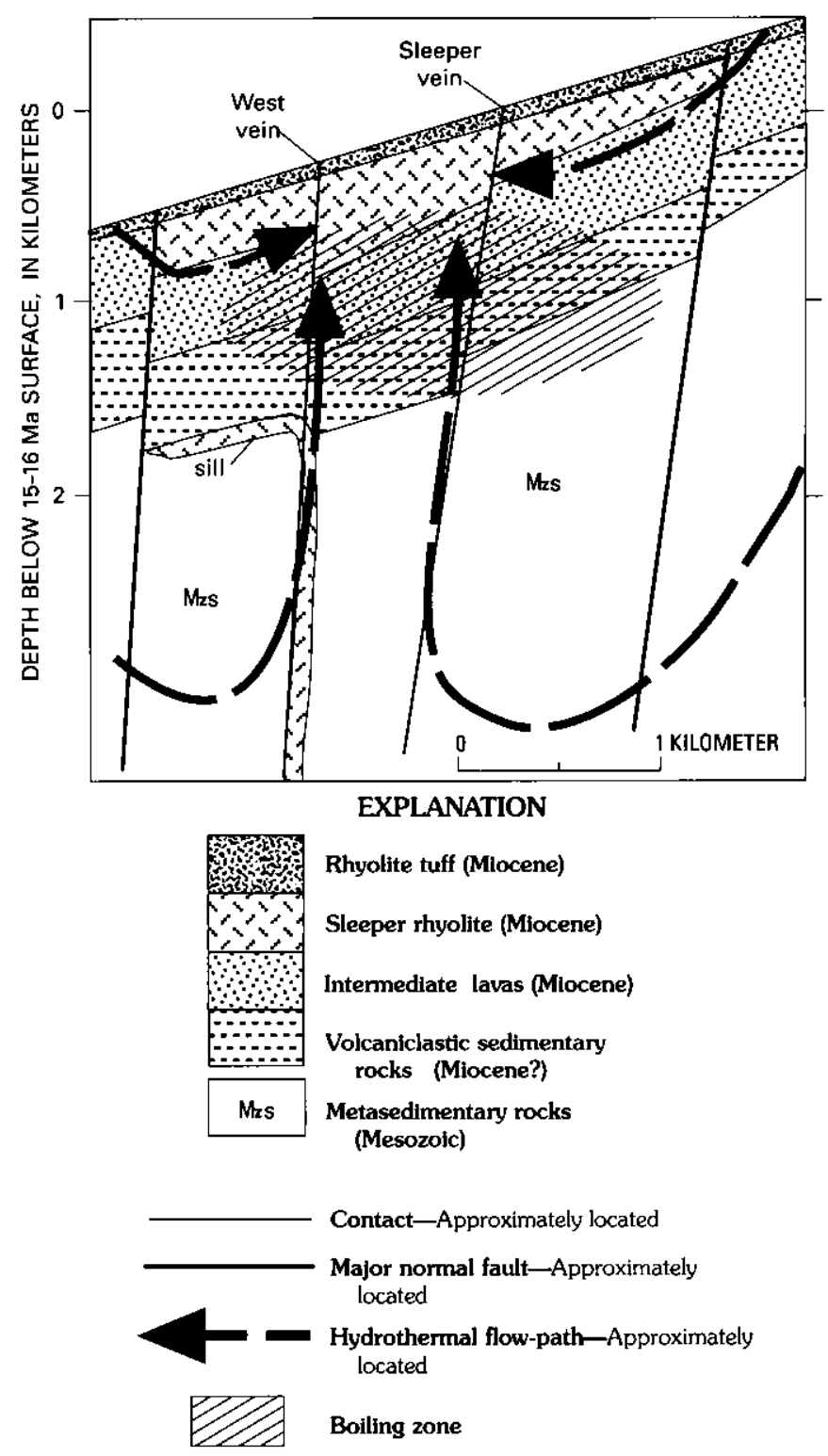

Figure 38. Schematic diagram of Sleeper geothermal system during formation of bonanza veins. At this time the zone of boiling may have been higher than at other times (compare fig. 37) and a flowpath through devitrifying rhyolite may have contributed a fluid supersaturated in silica, which mixed with the deeper boiling water near the base of the veins. 
to precipitate stibnite is by mixing with an acidic condensate. Stibnite and realgar or orpiment in hot springs and in Carlintype systems may be deposited in a similar manner (Berger and Henley, 1989).

Breccias and stockworks at Sleeper that are cemented by silica- $\mathrm{FeS}_{2}$ (pyrite+marcasite) may have formed in a zone of mixed bicarbonate-chloride waters. Mixing of deepseated chloride water with near-surface $\mathrm{CO}_{2}$-rich steamheated water (Hedenquist, 1991) is a newly recognized geothermal environment that is conducive to hydrolytic alteration and ore deposition. If steam-borne $\mathrm{CO}_{2}$ and $\mathrm{H}_{2} \mathrm{~S}$ accumulate below the water table, oxidation is minimized and extremely acidic, sulfate-rich fluids are not created; the alteration along breccia and stockwork structures at Sleeper indicates neutral to weakly acidic conditions. Deposition of silica and $\mathrm{FeS}_{2}$ at Sleeper could occur in response to mixing of an upwelling neutral, reducing chloride water carrying ferrous iron with cooler weakly acidic $\mathrm{CO}_{2}-\mathrm{H}_{2} \mathrm{~S}-\mathrm{SO}_{4}$ ground water. The concept of mixing is supported by pyrite textures, previously described, that indicate extreme supersaturation. The effectiveness of this process may depend on the amount of $\mathrm{H}_{2} \mathrm{~S}$ in the steam and the amount of oxidation at shallow levels, as well as the amount of Fe carried by the deep chloride water. The proposed mixing process is reducing in character and differs significantly from those involving surficial acid-sulfate waters that condense above the water table and create locally intense acid-leaching characterized by small or barren ore zones (Hedenquist, 1991; Stoffregen, 1987). This mixing model clearly is overly simplistic because, among other problems, it does not explain the very low $\mathrm{Cu}-\mathrm{Pb}-\mathrm{Zn}$ concentrations in the sulfidic deposits.

Geochemists have long debated the mechanisms and importance of chloride and sulfide complexes in ore transport and deposition (Barnes, 1979). Experimental studies demonstrate that both can form significant complexes with base and precious metals, and that solubility relations are very complicated in mixed chloride-sulfide solutions (for example, Wood and others, 1987; Hemley and others, 1992). In natural geothermal systems, base-metal concentrations tend to be higher in proportion to $\mathrm{Cl}$ (Henley and Ellis, 1983). White (1981, p. 409), seeking an explanation for compositional differences among epithermal deposits, suggested that "where other factors are equal, the base metals and Ag may travel farther and to lower temperatures in the more saline fluids." White suspected that $\mathrm{Cl}$ complexes are most important in the Ag-dominant (basemetal-rich) epithermal deposits, whereas sulfide complexes may be more important in Au-dominant deposits (rich in AsSb-Hg-Tl). This is consistent with determinations of high $\mathrm{H}_{2} \mathrm{~S}$ concentrations in the Au-rich, base-metal-poor, sediment-hosted ores at Jerritt Canyon, Nev. (Hofstra and others, 1991; Landis and Hofstra, 1991). Reaction-path modelling of an ore fluid with high $\mathrm{H}_{2} \mathrm{~S}$ and low $\mathrm{Cl}$ yields ore mineralogy and paragenesis identical to that observed at
Jerritt Canyon (Hofstra and others, 1991) and pertinent to Sleeper. Further research on fluids in gold deposits is needed to refine these estimates.

Much of the preceding speculation is simplistic and unconventional. We regret the lack of constraining factual data, but do not apologize for unconventional hypotheses as explanations for a very unusual world-class ore deposit. White (1981) raised the question of why so little ore-grade material had been encountered in modern geothermal systems. White's concern echoes our belief that unusually rich and large ore deposits are the result of a combination of unusual processes.

\section{SUMMARY}

The Sleeper gold-silver deposits formed in a local volcanic field during the early stages of basin-and-range extension $(\approx 15-16 \mathrm{Ma})$. The volcanic host rocks, silica-adulariasericite alteration, and enrichment in volatile elements (As, $\mathrm{Sb}, \mathrm{Hg}, \mathrm{Se}, \mathrm{Te}$ ) are features in common with the quartzadularia (sericite) class of epithermal deposits elsewhere. Application of geochemical models of ore formation developed from well-studied examples such as Creede provide some insights into processes of ore formation; for instance, boiling can explain many mineralogic features. However, Sleeper differs in many geologic and geochemical aspects from the Creede-type deposits, and the very rich bonanza gold veins at Sleeper are not easily explained by equilibrium thermodynamic models. Further, major differences between the two types of ores at Sleeper are difficult to explain by conventional ore deposit models. District- and deposit-scale geologic and geochemical features described here provide a qualitative framework for ore-forming conditions.

The volcanic environment at Sleeper was seemingly simple: a local field of flows, tuff cones, and flow-domes. No caldera exists in the area. For physical reasons the Sleeper rhyolite was the favored structural host for ore (it contains more than 90 percent of currently defined reserves). Regardless of whether the rhyolite body was an exogenous dome or a thick series of flows, the rigid, brittle character of the unit was optimum for brecciation and open-standing fractures. The style of alteration and geochronologic data do not indicate a direct magmatic tie to the rhyolite or a possible underlying magma chamber or stock for anything more than heat and possibly some magmatic volatiles. Stages of volcanism and ore formation accompanied episodic normal faulting during early stages of basin-and-range extension.

Basin-and-range normal faulting during a span of about 10-12 m.y. was important for both ore formation and preservation. The early stages of faulting are partly obscured by prominent younger faults, but at district scale early faults clearly controlled the formation of a lacustrine basin and the sites of numerous pre-ore volcanic vents and dikes. Multiple stages of hydrothermal alteration and ore formation occurred 
along this same zone. Renewed movement on the basin-andrange faults cut ore zones, but did not offset them so much as to make problems for present-day mining. A cumulative downdrop of about $1,000 \mathrm{~m}$ relative to the crest of the Slumbering Hills protected the deposits from major erosion that occurred in the middle to late Miocene.

Reconstruction of district geology at the time of ore formation, at about 15-16 Ma, indicates that only a relatively thin veneer of volcanic rocks, less than $600 \mathrm{~m}$ thick, was present. Based on incomplete information, the volcanic rocks appear to have had limited areal extent, possibly reflecting a local graben. The major normal faults must have penetrated metasedimentary basement rocks to depths of 4-6 $\mathrm{km}$. By analogy to modern geothermal systems around the world, the geothermal system must have involved a much greater volume of metasedimentary rocks than volcanic rocks. Gold veins of the Jumbo mine, as well as intercepts below the Sleeper mine, are indications of this deep circulation in fractured basement rocks. Reactions in the metapelitic rocks would have yielded fluids rich in $\mathrm{K}, \mathrm{CO}_{2}$, and $\mathrm{S}$; carbonaceous matter would have maintained reducing conditions reflected in $\mathrm{CH}_{4}$, and $\mathrm{HS}^{-}>\mathrm{SO}_{4}$. Geothermal water in the deeper part of the system would have attained a composition more akin to that below Carlin-type deposits than to typical volcanic-hosted epithermal deposits such as Creede. The composition of basement rocks, and fluids evolved in them, may explain some of the systematic differences at Sleeper relative to many volcanic-hosted systems, such as the low content of base metals and abundance of gold.

Miocene volcanic rocks are sulfidized and altered over a broad area around the Sleeper deposits. Alteration reactions could have released constituents that were deposited in ore zones. Alteration of andesitic and basaltic lavas below the deposits could reflect either a pre-ore geothermal system, or part of the precious metal system. Alteration in the mafic rocks may be related to widespread $\mathrm{Fe}-\mathrm{S}$ enrichment in low-grade stockwork ores in rhyolite; a possible mechanism for transport and deposition of these ore constituents is mixing of a chloride water (carrying $\mathrm{Fe}, \mathrm{Ag}$, and $\mathrm{Au}$ ) with a near-surface $\mathrm{CO}_{2}$-S-rich steam-heated water. The bonanza veins appear to have formed by different processes or different fluids. Supersaturation in silica was caused by reactions with glassy rhyolite. Enrichment of gold to the degree observed in the banded veins is not readily explained by conventional thermochemical models. The very rich gold grades and monomineralic bands of opal and electrum may be explained by a combination of (1) boiling a deep-sourced fluid; (2) mixing with a Si-supersaturated fluid from the rhyolite; (3) precipitation of colloidal silica and electrum as a result of cooling and loss of $\mathrm{H}_{2} \mathrm{~S}$; and (4) upward transport of colloidal particles until they were localized by gravitational separation or further cooling (Saunders, 1990).

No proven source is yet established for the gold at Sleeper. The large volume of metapelitic rocks reacting in the geothermal system is a more likely source than the relatively smaller volume of andesite or rhyolite. Such a source also is consistent with the time $(\approx 16 \mathrm{Ma})$ and space trend for gold-quartz-adularia veins in both pre-Tertiary metasedimentary and Miocene volcanic rocks in northwestem Nevada.

\section{REFERENCES CITED}

Albino, G.V., and Margolis, Jacob, 1991, Differing styles of adularia-sericite epithermal deposits-Contrasts in geologic settting and mineralogy: Geological Society of America Abstracts with Programs, v. 23, p. A230.

AMAX Gold Inc., 1991, Annual report 1990: Golden, Colo., AMAX Gold Inc., $40 \mathrm{p}$.

Anderson, J.A., 1982, Characteristics of leached capping and techniques of appraisal, in Titley, S.R., ed., Advances in geology of the porphyry copper deposits, Southwestem North America: Tucson, Ariz., University of Arizona Press, p. 275-296.

Barnes, H.L., 1979, Solubilities of ore minerals, in Barnes, H.L., ed., Geochemistry of hydrothermal ore deposits (Second Edition): New York, John Wiley, p. 404-460.

Barton, P.B., Bethke, P.B., and Roedder, E.E., 1977, Environment of ore deposition in the Creede mining district, San Juan Mountains, Colorado, part III-Progress toward interpretation of the chemistry of the ore-forming fluid for the $\mathrm{OH}$ vein: Economic Geology, v. 72, p. 1-24.

Berger, B.R., 1985, Geologic-geochernical features of hot-spring precious metal deposits, in Tooker, E.W., ed., Geologic characteristics of sediment- and volcanic-hosted disseminated gold deposits-Search for an occurrence model: U.S. Geological Survey Bulletin 1646, p. 47-54.

Berger, B.R., and Henley, R.W, 1989, Advances in the understanding of epithermal gold-silver deposits, with special reference to the westem United States, in Keays, R., Ramsay, R., and Groves, D., eds., The geology of gold deposits - The perspective in 1988: Economic Geology, Monograph 6, p. 405-423.

Black, J.E., Mancuso, T.E., and Gant, J.E., 1991, Geology and mineralization at the Rawhide Au-Ag deposit, Mineral County, Nevada, in Raines, G.L. and others, eds., Geology and ore deposits of the Great Basin: Reno, Nev., Geological Society of Nevada, p. 1123-1144.

Boyle, R.W., 1979, The geochemistry of gold and its deposits: Geological Survey of Canada Bulletin 280, 584 p.

Buchanan, L.J., 1981, Precious metal deposits associated with volcanic environments in the southwest, in Dickinson, W.R. and Payne, W.D., eds., Relations of tectonics to ore deposits in the Southern Cordillera: Tucson, Ariz., Arizona Geological Society Digest, v. 14, p. 237-262.

Burke, D.B., and Silberling, N.J., 1973, The Auld Lang Syne Group, of Late Triassic and Jurassic(?) Age, north-central Nevada: U.S. Geological Survey Bulletin 1394-E, p. E1-E14.

Calkins, F.C., 1938, Gold deposits of Slumbering Hills, Nevada: Nevada State Bureau of Mines Bulletin 32, no. 3, 23 p.

Carmichael, I.S.E., Turner, F.J., and Verhoogen, John, 1974, Igneous petrology: New York, McGraw-Hill, 739 p. 
Casadevall, T.J., and Ohmoto, Hiroshi, 1977, Sunnyside mine, Eureka mining district, San Juan County, Colorado--Geochemistry of gold and base-metal ore deposition in a volcanic environment: Economic Geology, v. 72, p. $1285-1320$.

Cathles, L.M., 1981, Fluid flow and genesis of hydrothermal ore deposits, in Skinner, B.J., ed., Seventy-Fifth Anniversary Volume: Economic Geology, p. 424-457.

Christiansen, R.I., and McKee, E.H., 1978, Late Cenozoic volcanic and tectonic evolution of the Great Basin and Columbia Intermontane regions, in Smith, R.B., and Eaton, G.P., eds. Cenozoic tectonics and regional geophysics of the western Cordillera: Geological Society of America Memoir 152, p. 283-311.

Cole, D.R., and Drummond, S.E., 1986, The effect of transport and boiling on $\mathrm{Ag} / \mathrm{Au}$ ratios in hydrothermal solutions; a preliminary assessment and possible implications for the formation of epithermal precious-metal ore deposits: Journal of Exploration Geochemistry, v. 25, p. 45-79.

Conrad, J.E., McKee, E.H., Rytuba, J.J., Nash, J.T., and Utterback, W.C., 1993, Geochronology of the Sleeper deposit, Humboldt County, Nevada-Epithermal gold-silver mineralization following emplacement of a silicic flow-dome complex: Economic Geology, v. 88, p. 317-327.

Conrad, W.K., 1984, The mineralogy and petrology of compositionally zoned ash flow tuffs and related silicic volcanic rocks, from the McDernitt caldera complex, Nevada-Oregon: Journal of Geophysical Research, v. 89, p. 8639-8664.

Drummond, S.E., and Ohmoto, Hiroshi, 1985, Chemical evolution and mineral deposition in boiling hydrothermal solutions: Economic Geology, v. 80, p. 126-147.

Duffield, W.A., Bacon, C.R., and Dalrymple, G.B., 1980, Late Cenozoic volcanism, geochronology, and structure of the Coso Range, Inyo County, Califormia: Joumal of Geophysical Research, v. 85, no. B5, p. 2381-2404.

Ellis, A.J., and Mahon, W.A.J., 1964, Natural hydrothermal systems and experimental hot-water/rock interactions: Geochimica et Cosmochimica Acta, v. 28, p. 1323-1357.

Eng, Tony, 1991, Geology and mineralization of the Freedom Flats gold deposit, Borealis mine, Mineral County, Nevada, in Raines, G.L., and others, eds., Geology and ore deposits of the Great Basin: Reno, Nev., Geological Society of Nevada, p. 995-1019.

Fisher, R.V., and Schmincke, H.-U., 1984, Pyroclastic rocks: New York, Springer-Verlag, $472 \mathrm{p}$.

Floyd, M.A., and Winchester, J.A., 1978, Identification and discrimination of altered and metamorphosed volcanic rocks using immobile elements: Chemical Geology, v. 21, p. 291-306.

Forster, Craig, and Smith, Leslie, 1990, Fluid flow in tectonic regimes, in Nesbitt, B.E., ed., Short course on fluids in tectonically active regimes of the continental crust: Mineralogical Association of Canada, Handbook, v. 18, p. $1-48$.

Fournier, R.O., 1985, The behavior of silica in hydrothermal solutions, in Berger, B.R., and Bethke, P.M., eds., Geology and geochemistry of epithermal systems: Society of Economic Geologists, Reviews in Economic Geology, v. 2, p. 45-61.
Full, R.P., and Grantham, R.M., 1968, Ore deposits of the Republic mining district, Ferry County, Washington, in Ridge, J.D., ed., Ore deposits of the United States, 1933-1967 (Graton-Sales Volume): New York, American Institute of Mining, Metallurgical, and Petroleum Engineers, v. 2, p. 1481-1494.

Gans, P.B., Mahood, G.A., and Schermer, Elizabeth, 1989, Synextensional magmatism in the Basin and Range province; a case study from the eastem Great Basin: Geological Society of America Special Paper 233, 53 p.

Garside, L.J., and Schilling, J.H., 1979, Thermal waters of Nevada: Nevada Bureau of Mines and Geology Bulletin 91, $163 \mathrm{p}$.

Graham, U.M., and Ohmoto, Hiroshi, 1992, Relationships between formational mechanisms and variations in properties of pyrite crystals synthesized at 150 to $350^{\circ} \mathrm{C}$ : Journal of Geochemical Exploration, v. 46, p. 239-241.

Halsor, S.P., Bornhorst, T.J., Beebe, Matt, Richardson, Kim, and Strowd, William, 1988, Geology of the DeLamar silver mine-A volcanic dome complex and genetically associated hydrothermal system: Economic Geology, v. 83, p. $1159-1169$.

Hayba, D.O., Bethke, P.M., Heald, Pamela, and Foley, N.K., 1985, Geologic, mineralogic, and geochemical characteristics of volcanic-hosted epithermal precious-metal deposits, in Berger, B.R., and Bethke, P.M., eds., Geology and geochemistry of epithermal systems: Society of Economic Geologists, Reviews in Economic Geology, v. 2, p. 129-167.

Heald, Pamela, Foley, N.K., and Hayba, D.O., 1987, Comparative anatomy of volcanic-hosted epithermal deposits-Acid-sulfate and adularia-sericite types: Economic Geology, v. 82, p. 1-26.

Hedenquist, J.W., 1991, Boiling and dilution in the shallow portion of the Waiotapu geothermal system, New Zealand: Geochimica et Cosmochimica Acta, v. 55, p. 2753-2765.

1992, Recognition of magmatic contributions to active and extinct hydrothermal systems, in Hedenquist, J.W., ed., Magmatic contributions to hydrothermal systems: Geological Survey of Japan, Report 279, p. 68-79.

Hedenquist, J.W., and Henley, R.W., 1985a, Hydrothermal eruptions in the Waiotapu geothermal system, New Zealand; their origin, associated breccias, and relation to precious metal mineralization: Economic Geology, v. 80, p. 1640-1688.

$1985 \mathrm{~b}$, The importance of $\mathrm{CO}_{2}$ on freezing point measurements of fluid inclusions-Evidence from active geothermal systems and implications for epithermal ore deposition: Economic Geology, v. 80, p. 1379-1406.

Hedenquist, J.W., Henley, R.W., Reyes, A.G., Simmons, S.F., and Taguchi, Sachihiro, 1992, The thermal and geochemical structure of geothermal and epithermal systems-A framework for interpreting fluid inclusion data: European Journal of Mineralogy, v. 4, p. 989-1015.

Hemley, J.J., Cygan, G.L., Fein, J.B., Robinson, G.R., and d'Angelo, W.M., 1992, Hydrothermal ore-forming processes in the light of studies in rock-buffered systems-I, Iron-copper-zinc-lead sulfide solubility relations: Economic Geology, v. 87 , p. $1-22$.

Henley, R.W., 1985, The geothermal framework for epithermal deposits, in Berger, B.R., and Bethke, P.M., eds., Geology and geochemistry of epithermal systems: Society of Economic Geologists, Reviews in Economic Geology, v. 2, p. 1-24. 
Henley, R.W., and Ellis, A.J. 1983, Geothermal systems ancient and modern; a geochemical review: Earth Science Reviews, v. 19 , p. $1-50$.

Hildreth, Wes, 1979, The Bishop Tuff, evidence for the origin of compositional zonation in silicic magma chambers, in Chapin, C.E., and Elston, W.E., eds., Ash-flow tuffs: Geological Society of America Special Paper 180, p. 43-75.

Hofstra, A.H., Leventhal, J.S., Northrop, H.R., Landis, G.P., Rye, R.O., Birak, D.J., and Dahl, A.R., 1991, Genesis of sedimenthosted disseminated-gold deposits by fluid mixing and sulfidation-Chemical-reaction-path modeling of ore-depositional processes documented in the Jerritt Canyon district, Nevada: Geology, v. 19, p. 36-40.

Irvine, T.N., and Baragar, R.A., 1971, A guide to the chemical classification of the common volcanic rocks: Canadian Journal of Earth Science, v. 8, p. 523-548.

Izawa, E., Urashima, Y., and others, 1990, The Hishikari gold deposit; high-grade epithermal veins in Quaternary volcanics of southem Kyushu, Japan, in Hedenquist, J.W., White, N.C., and Siddeley, Gordon, eds., Epithermal gold mineralization of the Circum-Pacific-Geology, geochemistry, origin, and exploration, Volume II: Journal of Exploration Geochemistry, v. 36 , p. $1-56$.

Johnson, M.G., 1977, Geology and mineral deposits of Pershing County, Nevada: Nevada Bureau of Mines and Geology Bulletin 89,115 p.; map scale 1:250,000.

Kyser, T.K., and Kerrich, Robert, 1990, Geochemistry of fluids in tectonically active crustal regions, in Nesbitt, B.E., ed., Short course on fluids in tectonically active regimes of the continental crust: Mineralogical Association of Canada, Handbook, v. 18 , p. $133-230$.

Landis, G.P., and Hofstra, A.H., 1991, Fluid inclusion gas chemistry as a potential minerals exploration tool-Case studies from Creede, CO, Jerritt Canyon, NV, Coeur d'Alene district, ID and MT, southern Alaska mesothermal veins and mid-continent MVT's: Journal of Geochemical Exploration, v. 42, p. 25-60.

Le Bas, M.J., Le Maitre, R.W., Streckeisen, A., and Zanettin, B., 1986, A chemical classification of volcanic rocks based on the total alkali-silica diagram: Joumal of Petrology, v. 27, p. $745-750$.

Le Maitre, R.W., ed., 1989, A classification of igneous rocks and glossary of terms: Oxford, Blackwell Scientific, 193 p.

Lehrman, N.J., 1986, The McLaughlin mine, Napa and Yolo Counties, California: Nevada Bureau of Mines and Geology Report 41, p. $85-89$.

Lipman, P.W., 1975, Evolution of the Platoro caldera area, southeastern San Juan Mountains, southwestem Colorado: U.S. Geological Survey Professional Paper 852, 128 p.

Love, L.G., and Amstutz, G.C., 1966, Review of microscopic pyrite: Fortschritt de Mineralogie, v. 43, p. 273-309.

Margolis, Jacob, Reed, M.H., and Albino, G.V., 1991, A processoriented classification of epithermal systems-Magmatic volatile-rich versus volatile-poor fluid paths: Geological Society of America Abstracts with Programs, v. 23, p. A230.

Meyer, Charles, and Hemley, J.J., 1967, Wall rock alteration, in Bames, H.L., ed., Geochemistry of hydrothermal ore deposits: New York, Holt, Rinehart, and Winston, p. 166-235

Murowchick, J.B., and Barnes, H.L., 1986, Marcasite precipitation from hydrothermal solutions: Geochimica et Cosmochimica Acta, v. 50 , p. $2615-2629$.
1987, Effects of temperature and degree of supersaturation on pyrite morphology: American Mineralogist, v. 72, p. 1241-1250.

Nash, J.T., 1972, Fluid-inclusion studies of some gold deposits in Nevada: U.S. Geological Survey Professional Paper 800-C, p. C15-C19.

1975, Fluid-inclusion studies of vein, breccia pipe, and replacement ores, northwestem San Juan Mountains, Colorado: Economic Geology, v. 70, p. 1448-1462.

Nash, J.T., and Bartlett, M.W., 1991, Progress on studies of Miocene volcanic rocks at the Sleeper gold-silver mine, Humboldt County, Nevada, in Thorman, C.H., ed., Some current research in eastern Nevada and western Utah by the U.S. Geological Survey: U.S. Geological Survey Open-File Report 91-386, p. 1-2.

Nash, J.T., Fey, D.L., Motooka, J.M., and Siems, D.F., 1990, Geochemical analyses of ore and host rocks, Sleeper goldsilver deposit, Humboldt County, Nevada: U.S. Geological Survey Open-File Report 90-702, 69 p. and diskette.

Nash, J.T., Utterback, W.C., and Saunders, J.A., 1991, Geology and geochemistry of the Sleeper gold deposits, Humboldt County, Nevada, an interim report, in Raines, G.L., and others, eds., Geology and ore deposits of the Great Basin: Reno, Nev., Geological Society of Nevada, p. 1063-1084.

Nelson, C.E., and Giles, D.L., 1985, Hydrothermal eruption mechanisms and hot spring gold deposits: Economic Geology, v. 80, p. 1633-1639.

Noble, D.C., McCormack, J.K., McKee, E.H., Silberman, M.L., and Wallace, A.B., 1988, Time of mineralization in the evolution of the McDermitt caldera complex, Nevada-Oregon, and the relation of middle Miocene mineralization in the northern Great Basin to coeval regional basaltic magmatic activity: Economic Geology, v. 83, p. 859-863.

Nolan, T.B., 1933, Epithermal precious-metal deposits, in Ore deposits of the Western States: New York, American Institute of Mining and Metallurgical Engineers, p. 623-640.

O'Neil, J.R., and Silberman, M.L., 1974, Stable isotope relations in epithermal Au-Ag deposits: Economic Geology, v. 69, p. 902-909.

Pearce, J.A., and Cann, J.R., 1973, Tectonic setting of basic volcanic rocks determined using trace element analyses: Earth and Planetary Science Letters, v. 19, p. 290-300.

Proffett, J.M., Jr., 1977, Cenozoic geology of the Yerington district, Nevada, and implications for the nature and origin of Basin and Range faulting: Geological Society of America Bulletin, v. 88, p. $247-266$.

Raiswell, R., 1982, Pyrite texture, isotopic composition and the availability of iron: American Journal of Science, v. 282, p. 1244-1263.

Reed, M.H., and Spycher, N.F., 1985, Boiling, cooling, and oxidation in epithermal systems-A numerical modelling approach, in Berger, B.R., and Bethke, P.M., eds., Geology and geochemistry of epithermal systems: Society of Economic Geologists, Reviews in Economic Geology, v. 2, p. 249-272.

Renders, P.J., and Seward, T.M., 1989, The adsorption of gold(I) complexes by amorphous $\mathrm{As}_{2} \mathrm{~S}_{3}$ and $\mathrm{Sb}_{2} \mathrm{~S}_{3}$ at 25 and $90^{\circ} \mathrm{C}$ : Geochimica et Cosmochimica Acta, v. 53, p. 255-267.

Reyes, A.W., 1990, Petrology of Philippine geothermal systems and the application of alteration mineralogy to their 
assessment: Journal of Volcanology and Geothermal Research, v. 43, p. 279-309.

Rimstidt, J.D., and Cole, D.R., 1983, Geothermal mineralization, I-The mechanism of formation of the Beowawe, Nevada, siliceous sinter deposit: American Joumal of Science, v. 283, p. 861-875.

Robinson, P.T., McKee, E.H., and Moiola, R.J., 1968, Cenozoic volcanism and sedimentation, Silver Peak Region, western Nevada and adjacent Califomia, in Coats, R.R., Hay, R.L., and Anderson, C.A., eds., Studies in volcanology: Geological Society of America Memoir 116, p. 577-611.

Romberger, S.B., 1988, Geochemistry of gold in hydrothermal deposits, in Shawe, D.R., Ashley, R.P., and Carter, L.M.H., eds., Introduction to geology and resources of gold and geochemistry of gold: U.S. Geological Survey Bulletin 1857-A, p. A9-A25.

Rose, A.W., and Burt, D.M., 1979, Hydrothermal alteration, in Barnes, H.L., ed., Geochemistry of hydrothermal ore deposits (Second Edition): New York, John Wiley, p. 173-235.

Ross, C.S., and Smith, R.L., 1961, Ash-flow tuffs; their origin, geologic relations, and identification: U.S. Geological Survey Professional Paper 361, $81 \mathrm{p}$.

Rye, R.O., Bethke, P.M., and Wasserman, M.D., 1992, The stable isotope geochemistry of acid-sulfate alteration: Economic Geology, v. 87, p. 225-262.

Rytuba, J.J., 1989, Geology of the volcanic-hosted Sleeper deposit, Humboldt Co., NV: Geological Society of America Abstracts with Programs, v. 21, p. 138.

Rytuba, J.J., and McKee, E.H., 1984, Peralkaline ash flow tuffs and calderas of the McDermitt volcanic field, southeast Oregon and north central Nevada: Journal of Geophysical Research, v. 89, no. B10, p. 8616-8628.

Sander, M.V., 1988, Geologic setting and the relation of epithermal gold-silver mineralization to wall rock alteration at the Round Mountain mine, Nye County, Nevada, in Schafer, R.W., Cooper, J.J., and Vikre, P.G., eds., Bulk mineable precious metal deposits of the Western United States: Reno, Nev., Geological Society of Nevada, p. 375-416.

Saunders, J.A., 1990, Colloidal transport of gold and silica in epithermal precious-metal systems-Evidence from the Sleeper deposit, Nevada: Geology, v. 18, p. 757-760.

1994, Silica and gold textures in bonanza ores of the Sleeper deposit, Humboldt County, Nevada-Evidence for colloids and implications for epithermal ore-forming processes: Economic Geology, v. 89, p. 628-638.

Saunders, J.A., Utterback, W.C., Day, W.C., and Christian, R.P., 1988, Characteristics of bonanza gold mineralization, Sleeper deposit, Nevada, U.S.A., in Proceedings of Bicentennial Gold '88: Geological Society of Australia, Abstract Series, no. 23, p. 386-388.

Schoen, Robert, White, D.E., and Hemley, J.J., 1974, Argillization by descending acid at Steamboat Springs, Nevada: Clays and Clay Minerals, v. 22, p. 1-22.

Seedorff, Eric, 1991, Magmatism, extension, and ore deposits of Eocene to Holocene age in the Great Basin-Mutual effects and preliminary proposed genetic relationships, in Raines, G.L., and others, eds., Geology and ore deposits of the Great Basin: Reno, Nev., Geological Society of Nevada, p. 133-178.
Silberman, M.L., 1985, Geochronology of hydrothermal alteration and mineralization-Tertiary epithermal precious-metal deposits in the Great Basin, in Tooker, E.W., ed., Geologic characteristics of sediment- and volcanic-hosted disseminated gold deposits-Search for an occurrence model: U.S. Geological Survey Bulletin 1646, p. 47-54.

Silberman, M.L., and Berger, B.R., 1985, Relationship of trace-element pattern to alteration and morphology in epithermal precious-metal systems, in Berger, B.R., and Bethke, P.M., eds., Geology and geochemistry of epithermal systems: Society of Economic Geologists, Reviews in Economic Geology, v. 2, p. 203-232.

Silberman, M.L., Johnson, M.G., Koski, R.A., and Roberts, R.J., 1973, K-Ar ages of mineral deposits at Wonder, Seven Troughs, Imlay, Ten Mile, and Adelaide mining districts in Central Nevada: Isochron/West, no. 8, p. 31-35.

Spooner, E.T.C., 1993, Magmatic sulfide/volatile interaction as a mechanism for producing chalcophile element enriched, Archean Au-quartz, epithermal $\mathrm{Au}-\mathrm{Ag}$ and $\mathrm{Au}$ skarn hydrothermal ore fluids: Ore Geology Reviews, v. 7, p. 359-379.

Spycher, N.F., and Reed, M.H., 1989, Evolution of a Broadlandstype epithermal ore fluid along altemative $\mathrm{P}-\mathrm{T}$ paths-Implications for the transport and deposition of base, precious, and volatile metals: Economic Geology, v. 84, p. 328-359.

Stewart, J.H., 1971, Basin and Range structure; a system of horsts and grabens produced by deep-seated extension: Geological Society of America Bulletin, v. 82, p. 1019-1044.

Stewart, J.H., and Diamond, D.S., 1988, Changing late Cenozoic tectonic patterns in western Nevada-A middle and upper Miocene extensional basin unrelated to present-day basin and range structure: Geological Society of America Abstracts with Programs, v. 20, p. 235.

Stoffregen, R.R., 1987, Genesis of acid-sulfate alteration and Au$\mathrm{Cu}-\mathrm{Ag}$ mineralization at Summitville, Colorado: Economic Geology, v. 82, p. 1575-1591.

Thompson, G.A., and Burke, D.B., 1974, Regional geophysics of the Basin and Range province: Annual Reviews of Earth Science, v. 2, p. 213-238.

Vikre, P.G., 1985, Precious metal vein systems in the National District, Humboldt County, Nevada: Economic Geology, v. 80, p. 360-393.

Wallace, A.R., 1991, Effect of late Miocene extension on the exposure of gold deposits in north-central Nevada, in Raines, G.L., and others, eds., Geology and ore deposits of the Great Basin: Reno, Nev., Geological Society of Nevada, p. 179-183.

Weissberg, B.G., 1969, Gold-silver ore-grade precipitates from New Zealand thermal waters: Economic Geology, v. 64, p. 95-108.

Weres, O., and Tsao, L., 1981, Chemistry of silica in Cerro Prieto brines: Geothermics, v. 10 , p. 255-276.

White, D.E., 1981, Active geothermal systems and hydrothermal ore deposits, in Skinner, B.J., ed., Seventy-Fifth Anniversary Volume: Economic Geology Publishing Co., p. 392-423.

White, D.E., Hutchinson, R.A., and Keith, T.E.C., 1988, The geology and remarkable thermal activity of Norris Geyser Basin, Yellowstone National Park, Wyoming: U.S. Geological Survey Professional Paper 1456, 84 p.

Willden, Ronald, 1964, Geology and mineral deposits of Humboldt County, Nevada: Nevada Bureau of Mines and Geology Bulletin 59, $154 \mathrm{p}$. 
Wilson, Marjorie, 1989, Igneous petrogenesis: London, Unwin Hyman, $466 \mathrm{p}$.

Wohletz, Kenneth, and Heiken, Grant, 1992, Volcanology and geothermal energy: Berkeley, Calif., University of California Press, $432 \mathrm{p}$.

Wood, J.D., 1988, Geology of the Sleeper gold deposit, Humboldt County, Nevada, in Schafer, R.W., Cooper, J.J., and Vikre, P.G., eds., Bulk mineable precious metal deposits of the Western United States: Reno, Nev., Geological Society of Nevada, p. 293-302.

1991, Geology of the Wind Mountain gold deposit, Washoe County, Nevada, in Raines, G.L., and others, eds., Geology and ore deposits of the Great Basin: Reno, Nev., Geological Society of Nevada, p. 133-178.

Wood, J.D., and Hamilton, S.K., 1991, The Sleeper gold-silver deposit; discovery through feasibility, in Hutchinson, R.W., and Grauch, R.I., eds., Mineral deposits - Case histories and historical perspectives of genetic concepts: Society of Economic Geologists Monograph 8, 359 p.

Wood, S.A., Crerar, D.A., and Borcsik, M.P., 1987, Solubility of the assemblage pyrite-pyrrhotite-magnetite-sphalerite-galenagold-stibnite-bismuthinite-argentite-molybdenite in $\mathrm{H}_{2} \mathrm{O}$ $\mathrm{NaCl}-\mathrm{CO}_{2}$ solutions from $200^{\circ}$ to $350^{\circ} \mathrm{C}$ : Economic Geology, v. 82 , p. $1864-1887$. 



.
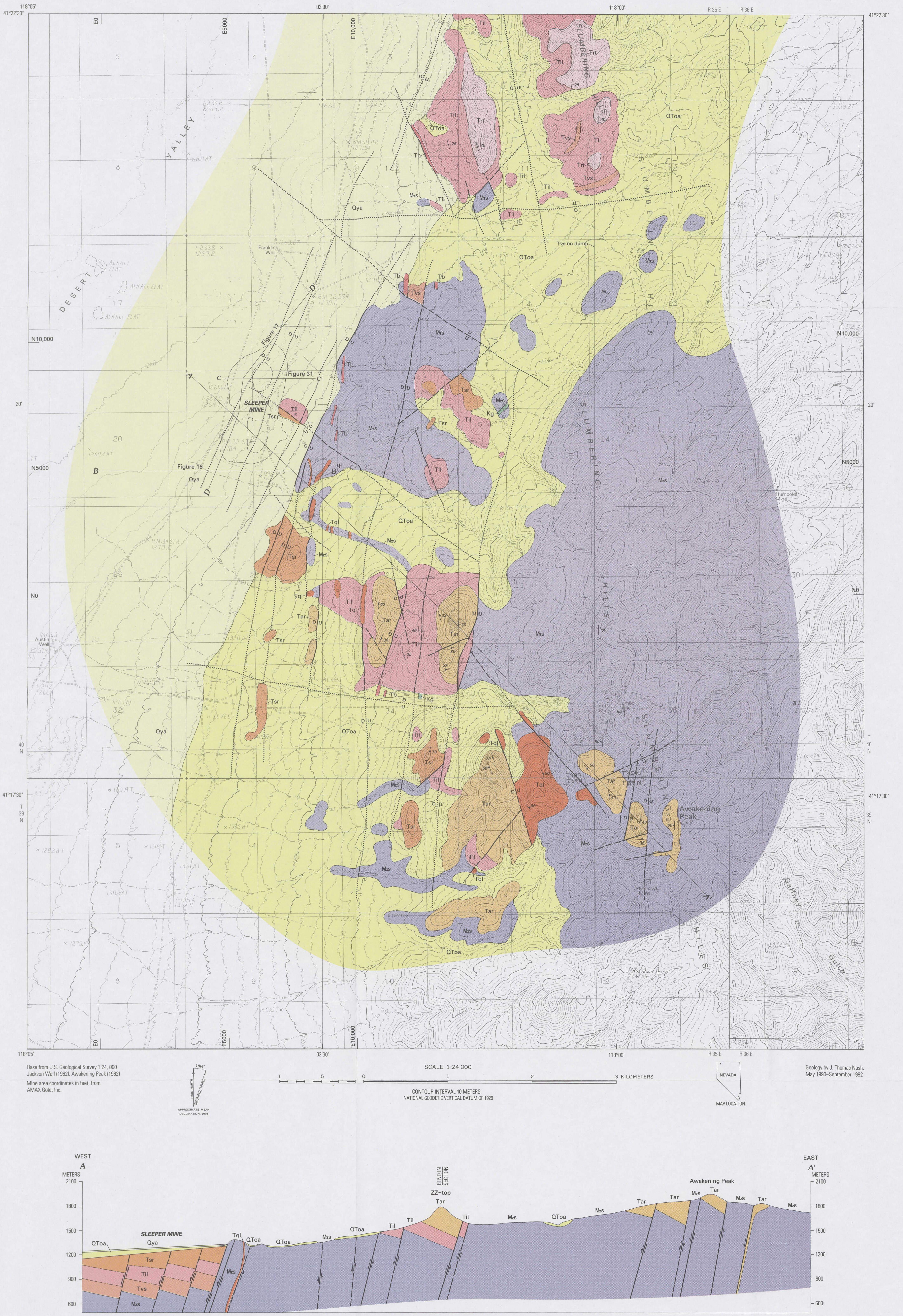

MAP SHOWING GEOLOGY OF SLUMBERING HILLS IN VICINITY OF THE SLEEPER MINE, HUMBOLDT COUNTY, NEVADA

By
J. Thomas Nash, William C. Utterback, and Wayne S. Trudel
1995 


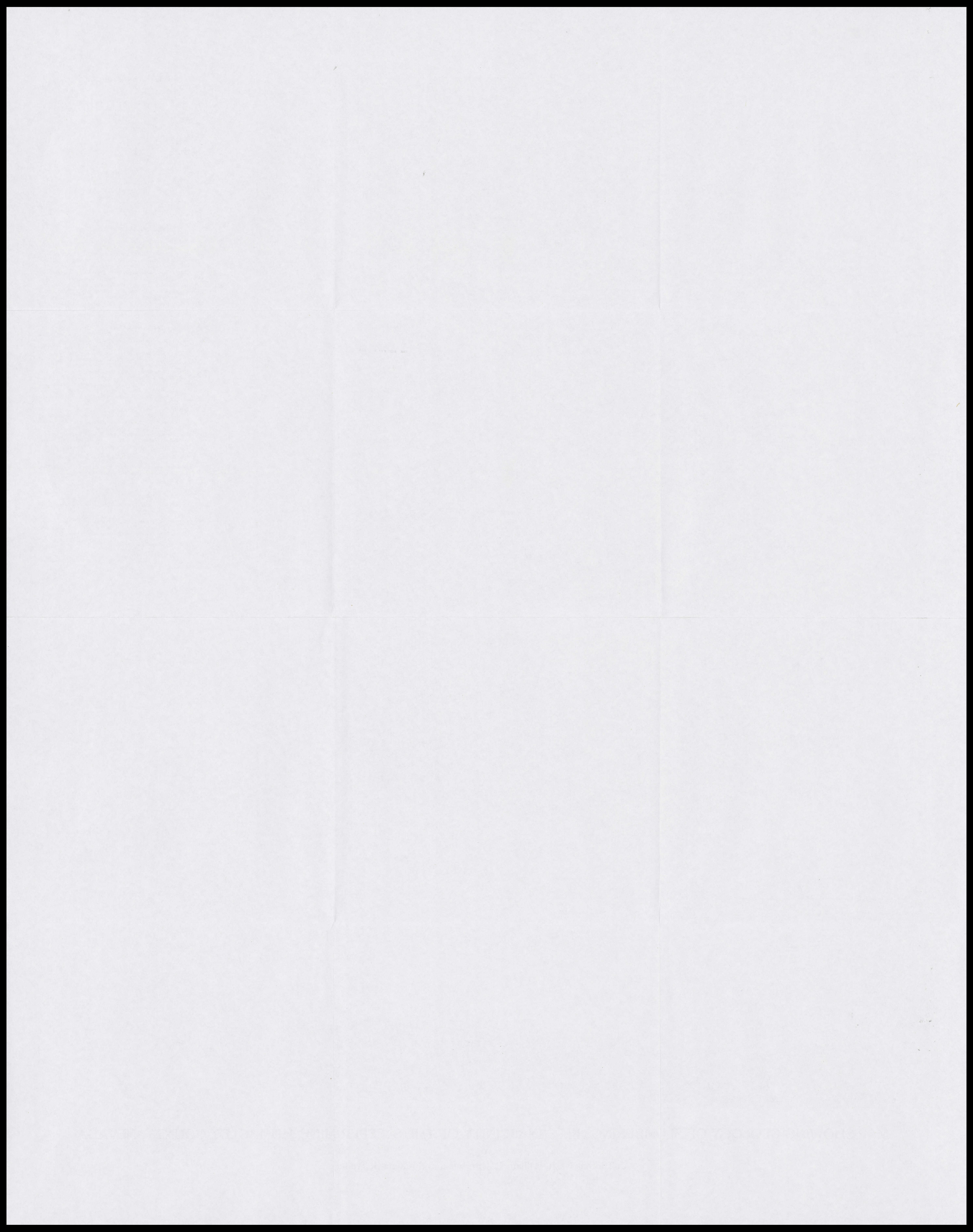



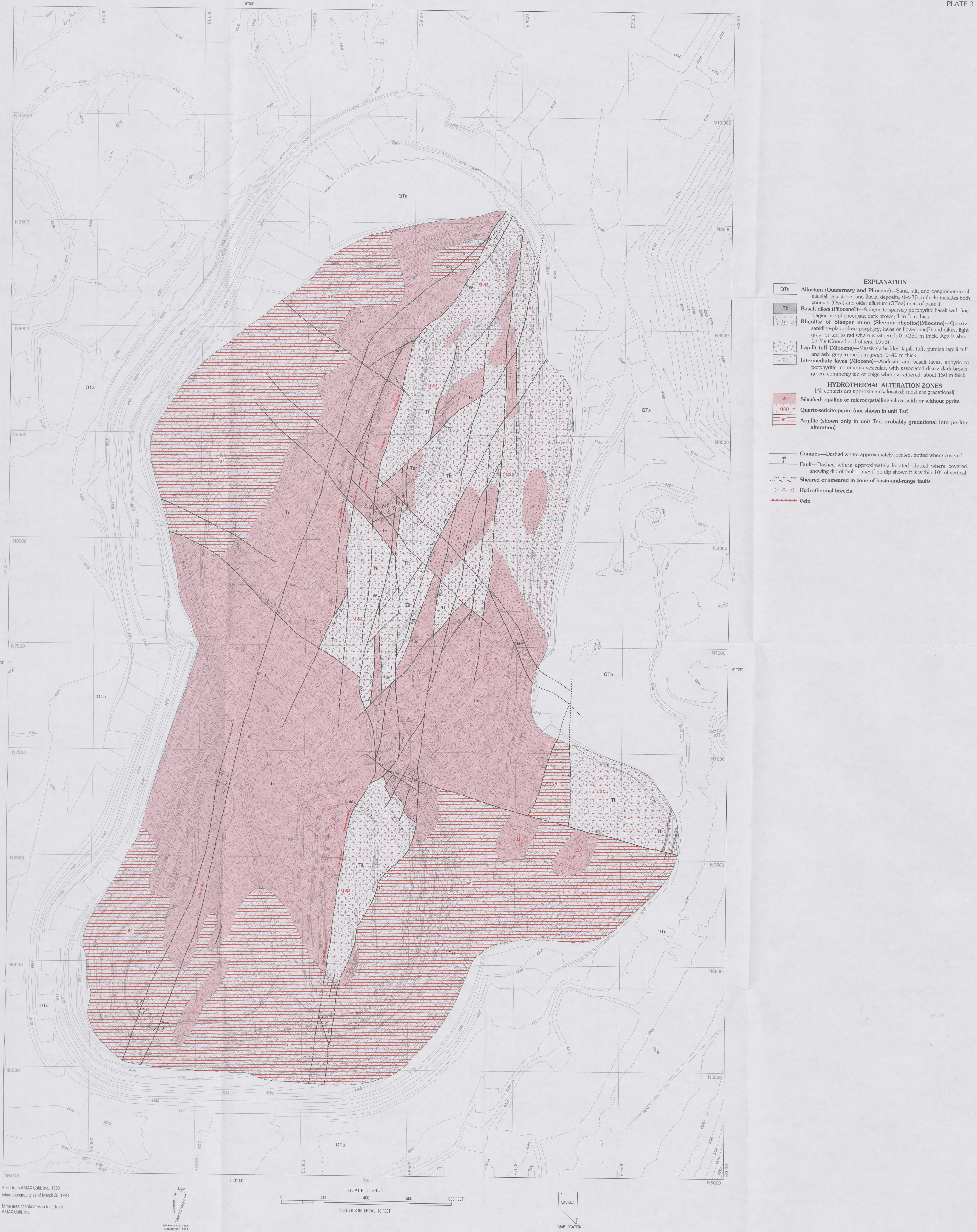
